\title{
Revista Română de Terapia
}

\section{Tulburărilor de Limbaj și Comunicare}

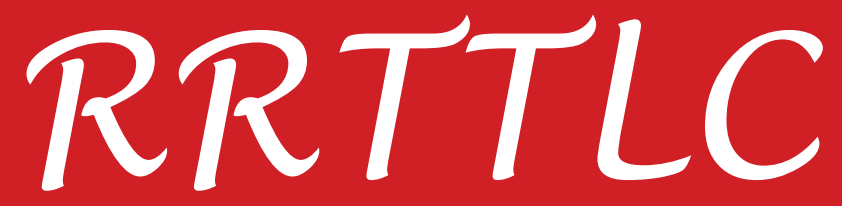

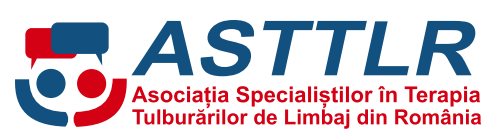
Afiliată
Publicație bianuală editată de ASTTLR

Apare în

Martie \& Octombrie
Vol.VII Nr. 1 An 2021

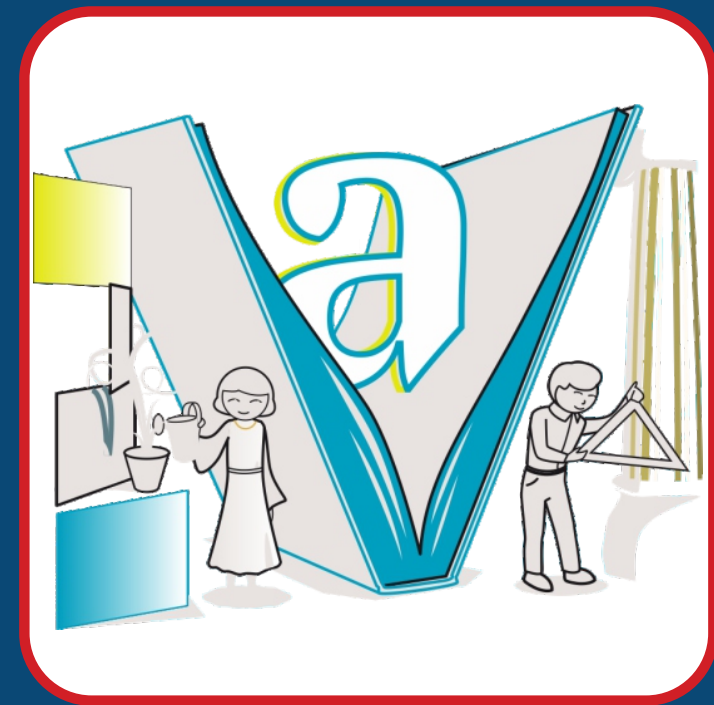




\section{CUPRINS}

EDITORIAL

2

CAROLINA BODEA HATEGAN

AUTO-COMPASIUNEA ȘI AUTO-EFICACITATEACA - RESURSE PERSONALE

ÎN CAZUL TERAPEUȚILOR

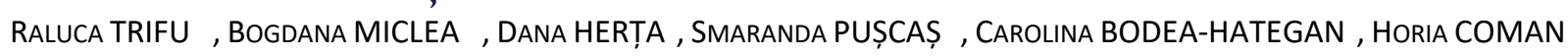

IMPACTUL MANAGEMENTULUI DISFAGIEI ASUPRA CALITĂT,II VIET,II

PERSOANELOR CU ACCIDENT VASCULAR CEREBRAL

ABORDAREA INTERDISCIPLINARĂ A DESPICĂTURILOR FACIO-LABIO-

PALATINE

STUDIU PRIVIND ACTIVITĂȚILE DE PREVENIRE A TULBURĂRILOR DE

LIMBAJ ÎN GRĂDINIT,E.

SIMONA BIANCA ROȘCA

DIMINUAREA DIFICULTĀṬILOR DE PREDARE-ÎNVĀȚARE ÎN SISTEMUL ON-

LINE

ROLUL IMPLICĂRII PARENTALE ÎN PROCESUL DE INTERVENȚIE

LOGOPEDICĂ

LUCIA BOTEZAT

AUTISM, SCHIZOFRENIE, ADHD. PERSPECTIVE CONVERGENTE. BOGDANA MICLEA

PREACHIZIȚII ÎN ÎNVĂȚAREA SCRIS-CITITULUI LA COPIII CU TULBURĂRI

DE INVĂT,ARE IOANA MATEI

EVALUARE ȘI INTERVENȚIE LOGOPEDICĂ ÎN CONTEXTUL ÎNTÂRZIERII ÎN

DEZVOLTAREA LIMBAJULUI- .

RESURSELE MATERIALE S,I VIRTUALE UTILIZATE ÎN TERAPIA

TULBURĂRILOR DE LIMBAJ. STUDIU DESCRIPTIV BAZAT PE FOCUS-GRUP 


\section{Editorial}

\section{Carolina BODEA HAŢEGAN ${ }^{1,2}$}

Numărul 1 al Revistei Române de Terapia Tulburărilor de Limbaj și ComunicareRRTTLC din anul 2021 este un număr ce aduce în prim plan preocupările recente din domeniul terapiei tulburărilor de limbaj și comunicare. Astfel, tematica centrală este cea a terapiei derulate online și a modului în care acest tip specific de demers terapeutic și educațional poate fi îmbogățit, dezvoltat sau utilizat împreună cu modalitățile clasice de implementare a programelor de intervenție logopedică. Resursele terapeutice sunt un alt capitol important, abordat tot din perspectiva noului scenariu în care se derulează, nu numai activitățile educaționale și terapeutice, dar mare parte din preocupările noastre cotidiene. În aceste condiții, auto-compansiunea și autoeficacitatea sunt propuse drept soluții pertinente, pentru terapeuții și profesioniștii din domeniul medical.

Sub aspectul categoriilor diagnostice din sfera terapiei tulburărilor de limbaj și comunicare, articolele cuprinse în acest număr al revistei vizează: întârzierea în dezvoltarea limbajului, tulburările de înghițire și alimentație, tulburările de limbaj din contextul spectrului autist, a ADHD-ului, a tulburărilor psihopatologice, tulburările de limbaj datorate despicăturilor facio-labiopalatine, precum și tulburările de limbaj scris-citit. De asemenea, un alt aspect vizat la nivelul studiilor cuprinse în acest număr este cel al prevenției și intervenției timpurii, în sfera terapiei logopedice, unde clar pe lângă rolul terapeutului reflexiv și informat, rolul părintelui implicat și cunoscător este la fel de valoros și de dorit.

Este de remarcat faptul că întregul număr al revistei propune cititorilor materiale de specialitate lucrate atât din perspectiva teoreticianului, cât și din perspectiva practicianului, care își organizează demersurile educaționale și cele terapeutice bazat pe dovezi științifice și date care să suțină generalizarea rezultatelor obținute. Prin urmare, propunem cititorilor un număr cu articole, bogate sub aspect informațional și cu date desprinse din demersuri comprehensive de cercetare. Aceste articole pot fi considerate veritabile modele de bună practică, modele ce pot fi replicate și prin care preocupările naționale sunt racordate la cele internaționale.

Vă dorim lectură plăcut și experiențe fructuoase de învățare și dezvoltare profesională!

Cluj-Napoca 24.03.2021

1. Conf. univ. dr., Departamentul de Psihopedagogie Specială, Facultatea de Psihologie şi Ştiințe ale Educației, Universitatea Babeș-Bolyai, Cluj-Napoca; E-mail:carolina.bodea.hategan@gmail.com

2.Preşedinte ASTTLR 


\title{
Auto-compasiunea și auto-eficacitateaca - resurse personale în cazul terapeuților
}

\section{Raluca TRIFU ${ }^{*}$, Bogdana MICLEA ${ }^{2^{*}}$, Dana HERȚA ${ }^{3}$, Smaranda PUȘCAȘU ${ }^{4}$, Carolina BODEA-HATEGAN 5 , Horia COMAN $^{6}$}

\begin{abstract}
One of the special human qualities is the compassion shown towards our fellow, in special situations, people who live certain states determined by the moments of life they go through.

Self-compassion refers to the ability to show compassion, understanding and protection to oneself. It is operationalized by researcher Kristin Neff. Self-efficacy, proposed by Albert Bandura, refers to the perception of self and is related to the belief in one's own abilities, in one's own ability to solve situations.

The interest of the study aims the relationship between self-compassion and self-efficacy in the case of a distinct category, that of therapists, professionally faced with situations that require personal resources.

Methods: The level of self-compassion was assessed with the Self-Compassion Scale, 26 items, proposed by Kristin Neff. The level of self-efficacy was assessed using the New General Self-Efficacy Scale, the 8-item scale proposed by Gilad Chen \& co (2001). Both questionnaires were distributed electronically. The data obtained were statistically analyzed and interpreted.

Results: In the professional categories investigated, there are underline links and relations between the two constructs, with professional implications. The results show (1) Therapists have high values in assessing selfefficacy; (2) Therapists have high values of self-compassion; (3) Therapists have a high level of self-compassion and a low level of self-criticism as indicated by the self-compassion sub-scales; (4) There is a direct relationship between self-efficacy and self-compassion; (5) Therapists with high level of self-compassion also have a high level of self-efficacy (6) The level of self-efficacy is influenced by age and professional experience. (7) The level of self-compassion is influenced by age and professional experience
\end{abstract}

Conclusion: The two concepts discussed are important in relation to certain professional categories and under the auspices of situations considered stressful and with emotional burden.

Keywords: self compassion, self efficacy, personal resources, therapist resources, SelfCompassion Scale

\section{Introducere}

Una dintre calitățile umane deosebite este compasiunea manifestată față de semenii noștri aflați în situații deosebite, persoane care trăiesc anumite stări determinate de momentele de viață pe care le traversează. Paul Gilbert. anunța, încă din introducerea la cartea sa intitulată Compasiunea și mintea umană, faptul că definirea compasiunii poate să fie realizată în multe moduri, dar „esența sa este bunăvoința, cu o conștientizare profundă a propriei suferințe și a celei resimțite de alte ființe, însoțită de dorința și încercarea de a alina"(Gilbert, 2020 p.11). Interesul asupra compasiunii ca subiect de studiu a crescut semnificativ în ultimii ani, tot mai multe cercetări vizând înțelegerea conceptului, dar și a modului în care compasiune poate influența capacitatea oamenilor de a depăși dificultățile în viață, dar și de a crea sentimente de împlinire. În prezent cercetători cu interese diverse explorează 
importanța bunăvoinței și afecțiunii, precum și modalitățile prin care ele pot să fie valorificate. Începând din anii 2000 cercetătoare americană Kristin Neff a explorat, încadrat și cuantificat conceptul de compasiune raportat la propria persoană, teoretizând, operaționalizând și aplicând conceptul de auto-compasiune (K. Neff, 2003). Auto-compasiunea se referă la capacitatea de a manifesta compasiune, înțelegere și protecție către propria persoană. Manifestarea autocompasiunii are implicații asupra funcționalității și eficienței persoanei în relațiile sale $\mathrm{cu}$ societatea și în relațiile sale. Impactul aplicării auto-compasiunii a fost documentat prin numeroase studii de către autoare conceptului. Relația autocompasiunii cu trauma, stima de sine, starea de sănătate, funcționarea fiziologică, burn-out-ul, reziliența sunt doar câteva dintre relațiile studiate.

De interes pentru prezentul studiu este relația dintre autocompasiune și autoeficacitate, relație care anterior nu a fost explorată.

Auto-eficacitatea este un concept care se referă la perceperea propriei persoane și este legată de credința în propriile abilități, în propria capacitate de a rezolva probleme. Poate deține valențe pozitive și negative. Conceptul a fost propus de Bandura, A. într-o lucrare ce teoretiza și operaționaliza această idee(Bandura, 1997). Auto-eficacitatea, așa cum este prezentată de către Bandura (1997), reprezintă un set de judecăți, raționamente ce se leagă de capacitatea indivizilor de a iniția și a realiza o sumă de acțiuni, necesare pentru a atinge performanțe în diferite domenii de activitate. Auto-eficacitatea propusă de
Bandură trebuie privită în contextul teoriei social-cognitive. Unii autori atrăgeau atenția asupra diferențierii dintre auto-eficacitate legată de câmp, adică acea auto-eficacitate care are impact asupra unui comportament, în comparația cu auto-eficacitatea manifestată în domeniul profesional (Tăut \& Băban, 2008), iar alți autori propun o auto-eficacitate intracâmp, adică autoevaluarea abilităților în ceea ce privește menținerea unui model (Dijkstra \& De Vries, 200o).

Pornind de la conceptul teoretic propus de Bandura s-a ajuns la operaționalizarea şi măsurarea conceptului. Amintim în acest sens lucrările lui Bentz (Betz \& Klein, 1996) și mai recent Chen (Chen et al., 2001)

Întrucât la baza auto-eficacității se află individul și implicit relația acestuia cu comportamentul său și cu mediul înconjurător, percepția sinelui și a abordării sale devine semnificativă și poate avea implicații în procesele de aplicare a conceptelor psihologice la viața de zi cu zi, în vederea creșterii stării de bine și de performanță.

\section{Obiectivul studiului}

Interesul studiului rezidă în observarea relației dintre auto-compasiune și autoeficacitatea în cazul unei categorii distincte, cea a terapeuților, confruntați profesional cu situații care solicită resursele personale.

\section{Material și metodă}

\section{Instrumente}

Pentru evaluarea relației dintre autocompasiune și auto-eficacitate s-a folosit două chestionare diferite. Nivelul de autocampasiunea a fost evaluat cu scala SelfCompassion Scale (SAC) , 26 de itemi, 
propusă de Kristin Neff. Scala este disponibilă în limba engleză pe pagina web a autoarei (K. Neff, 2021). Scala cuprinde mai multe dimensiuni de evaluare a auto-compasiunii. Aceste vor fi prezentate în continuare

Tabel nr 1- Distribuția itemilor scalei SAC pe dimensiuni

\begin{tabular}{ll}
\hline \hline Dimensiune & Item reprezentativ \\
\hline \hline Self-Kindness & $5,12,19,23,26$ \\
\hline Self-Judgment & $1,8,11,16,21$ \\
\hline Common Humanity & $3,7,10,15$ \\
\hline Isolation & $4,13,18,25$ \\
\hline Mindfulness & $9,14,17,22$ \\
\hline Over-identified & $2,6,20,24$ \\
\hline SCS - Scor general & $\begin{array}{l}\text { Media cu cotare inversă } \\
\text { pentru Self-Judgment, } \\
\text { Isolation, Over- } \\
\text { identified }\end{array}$ \\
\hline \hline
\end{tabular}

Nivelul de auto-eficacitate a fost evaluat $\mathrm{cu}$ ajutorul New General Self-Efficacy Scale (SAC), scală în 8 itemi propusă de Gilad Chen\&co (2001). Ambele chestionare au fost distribuite electronic. Datele obținute au fost prelucrate și interpretate statistic.

\section{Metodă}

Pentru realizarea prezentului studiu s-a apelat la cele două instrumente de evaluare a auto-eficacității respectiv autocompasiunii. Pentru scala de autocompasiune (SAC) s-a solicitat și s-a primit în prealabil acordul autoarei pentru utilizarea scalei în scop de cercetare. Scala de evaluare a auto-eficacității a fost propusă de Gilad Chen\&co (2001) pe baza conceptului inițial a lui Albert Bandura. Scala de evaluare a auto-eficacității (SAE) este disponibilă prin platforma
SPARQtools pusă la dispoziție de Standford (SPARQtools, 2021).

SPARQtools sunt seturi de instrumente digitale care facilitează accesul la cercetare prin formate ușor de utilizat, pe care practicienii și educatorii le pot folosi în scopul măsurării schimbărilor psihologice, comportamentale și societale. Fiecare set de instrumente împărtășește materiale și resurse bazate pe dovezi care pot fi puse la dispoziție pentru a aborda probleme actuale cu care oamenii se confruntă în prezent. Chestionarul de evaluare a autoeficacității, intitulat în limba engleză New General Self-Efficacy Scale este un instrument din kit-ul intitulat Measuring Mobility Toolkit pus la dispoziției cercetătorilor în scop de cercetare și evaluare. Chestionarul propus de Chen și colaboratorii săi (Chen et al., 2001) evaluează un nivel general al autoeficacității percepute și reflectă capacitatea de a rezolva situații

Cele două instrumente de cercetare au fost traduse în limba română de către 2 traducători profesioniști, prin procedură de traducere și retraducere, și adaptate. Ambele chestionare au fost transpuse în format electronic distribute on line în grupurile de specialitate sau prin invitație de participare la studiu

Procedura ulterioară a presupus ca datele obținute au fost prelucrate și interpretate statistic în vederea observării unor posibile relații dintre SAE şi SAC.

\section{Participanți}

Participanții la studiu au fost un număr de 43 de terapeuți, de vârste diferite și cu competențe diferite, mai exact psihoterapeuți, psihopedagogi, terapeuți de limbaj, terapeuți specializați în 
domeniul îngrijirilor paliative, kinetoterapeuți. Distribuția a fost echilibrată, exceptând grupa de vârsta de peste 60 de ani care a avut doar un participant. Majoritatea participanților sau situat în intervalul de vârstă 41-50 de ani. Distribuirea participanților în funcție de vârstă este observabilă în graficul următor (figura nr. 1).

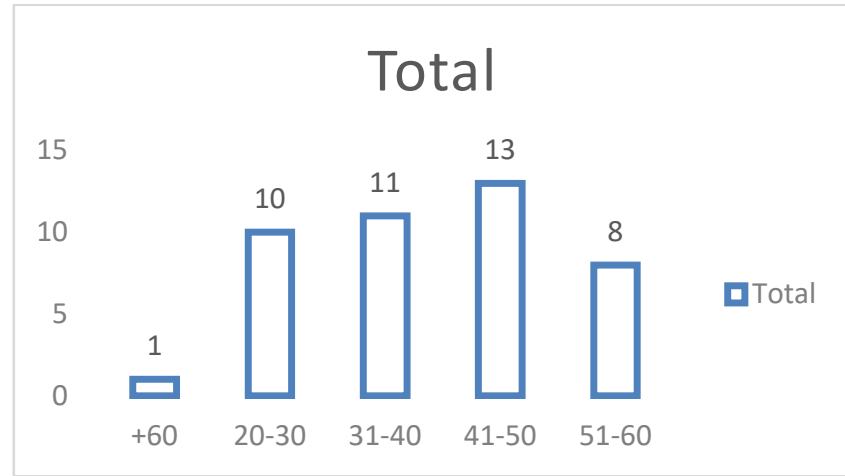

Figura nr 1. Distribuția lotului de participanți raportat la vârsta participaților

În ceea ce privește experiența profesională a participanților la studiu, majoritatea participanților se află deja în sectorul terapeuților cu experiență. Un număr relativ mare dintre participanți au o experiență profesională peste 5 ani. Distribuția experienței profesionale este prezentată în graficul următor(fig. nr.2).

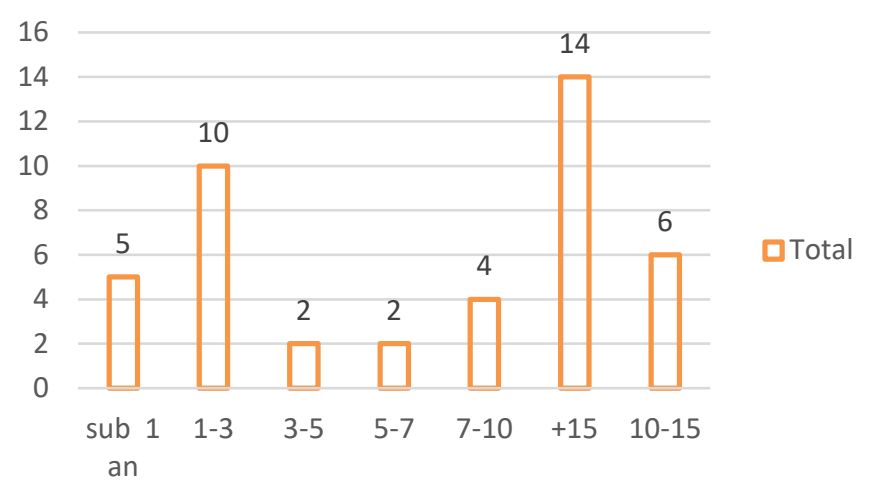

Figura nr. 2 - Distribuția lotului de participanți în funcție de experiența profesională.

\section{Rezultate}

Rezultatele obținute în urma prelucrărilor statistice indică valori diferite raportate la vârsta și experiența pe care terapeuții o au, dar și legături directe între cele două concepte, prin prisma raportării individuale și de grup. $\mathrm{Nu}$ a fost observată nicio diferență între scorurile obținute de terapeuți la scalele de auto-compasiune și auto-eficacitate, raportate la tipul de terapie practicat.

Astfel pentru scala de auto-eficacitate, valoarea minimă înregistrată a fost de 2.37, iar maximum de 4.87, cu o medie de 4.09 puncte. Acest lucru semnifică faptul că la nivelul grupului, nivelul de autoeficacitate perceput este crescut, dar că există și rezultate individuale care indică o percepție scăzută a propriei eficacități.

Tabel nr. 2. - Rezultatele obținute la scala auto-eficacitate - valori minime și maxime

Valori medii ale scalei de AE

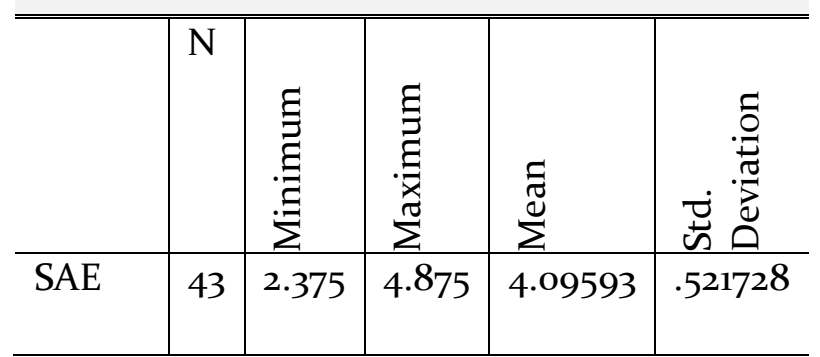

În ceea ce privește rezultatele obținute la scala de auto-compasiune putem observa scoruri crescute pentru dimensiunile $\mathrm{cu}$ valență pozitivă și scoruri scăzute la itemii cu valență negativă, notați cu ,- " în tabelul nr. 3. Este notabil faptul că terapeuții înregistrează un minimum de 1 pct pentru dimensiunile cu valență negativă de auto-critică $\mathrm{M}=2,367$ (SD \pm .868$)$, izolare $\mathrm{M}=2,36 \quad(\mathrm{SD} \pm .90)$ și supra-identificare $\mathrm{M}=2,79$ ( $\mathrm{SD} \pm .929)$, dar în același timp ating și un maxim de 4.4 (auto-critică) și 4.5(izolare) sau chiar 5.00 
(supra-identificare). În compensare, dimensiunile cu valență pozitivă înregistrează valori maxime la 2 din cele 3 dimensiuni, auto-compasiunea având însă cea mai mică valoare de 4.39 pentru palierul superior și o medie de $M=3.368$

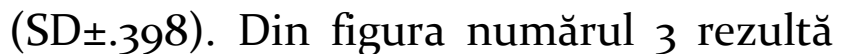
însă, așa cum era de așteptat că dimensiunile cu valență negativă sunt la praguri scăzute pe grafic, iar cele cu valență pozitivă sunt la nivel superior pe graficul (fig. nr. 3)

Tabel nr 3-Rezultatele obținute la scala de auto-compasiune, în funcție de medii și valorile prag

Valori medii ale SCS și factorilor SCS

\begin{tabular}{lllllll}
\hline & & $\mathrm{N}$ & Minimum & Maximum & Mean & Std. Deviation \\
\hline Self-Kindness & + & 43 & 2.0 & 5.0 & 3.670 & .6927 \\
\hline Self Judgement & - & 43 & 1.0 & 4.4 & 2.367 & .8684 \\
\hline $\begin{array}{l}\text { Common } \\
\text { Humanity }\end{array}$ & + & 43 & 1.00 & 5.00 & 3.6628 & .90778 \\
\hline Isolation & - & 43 & 1.00 & 4.50 & 2.3023 & .90724 \\
\hline Mindfulness & + & 43 & 2.00 & 5.00 & 4.0349 & .77648 \\
\hline $\begin{array}{l}\text { Over- } \\
\text { Identification }\end{array}$ & - & 43 & 1.25 & 5.00 & 2.7965 & .92944 \\
\hline $\begin{array}{l}\text { Auto- } \\
\text { compasiunea }\end{array}$ & + & 43 & 2.51 & 4.39 & 3.3688 & .39842 \\
\hline SAE & 43 & & & 4.09593 & .521728 \\
\hline \hline
\end{tabular}

\section{Relația dintre AE -SES}

Între rezultatele obținute la scala de auto-compasiune și scala de auto-eficacitate există o relație directă semnificativă statistic, $\mathrm{R}=.363, \mathrm{p}=0.05$ ( tab.nr. 4)

Tabel nr 4- Relația dintre auto-compasiune și auto-eficacitate în lotul de studiu

\begin{tabular}{llll}
\hline \hline & & Auto-eficacitatea & Auto-compasiunea \\
\hline \hline $\begin{array}{l}\text { Scala de auto- } \\
\text { eficacitate (SAE) }\end{array}$ & Pearson Correlation & 1 & $.363^{*}$ \\
\cline { 2 - 4 } & Sig. (2-tailed) & 43 & .017 \\
\cline { 2 - 4 } & $\mathrm{N}$ & 43 \\
\hline \multirow{2}{*}{ *. Correlation is significant at the 0.05 level (2-tailed). } & \\
\hline \hline
\end{tabular}

Din graficul nr. 4 se poate observa că la nivelul lotului studiat scoruri mai crescute au fost pe scala de auto-eficacite în comparație cu scala de auto-compasiune. 

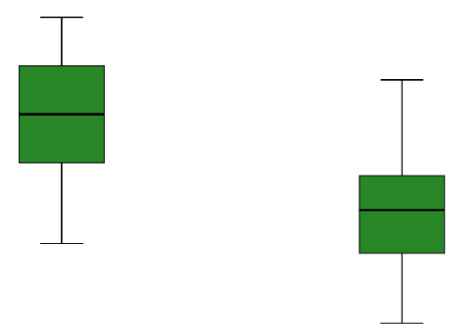

Figura $n r .4$ - Raportarea rezultatelor medii la SAC(scala de auto-compasiune) și SAE( scala de auto-eficacitate)

În evaluarea detaliată a relației dintre auto-eficacitate și fiecare dimensiune a scalei de auto-compasiune se poate observa din tabelul următor că scala de Tabel nr 5-Relația dintre auto-eficacitate și auto-compasiune și relația în interiorul scalei SAC

Relația SAE cu fiecare subscală SCS

\begin{tabular}{|c|c|c|c|c|c|c|c|c|}
\hline & & SAE & $\begin{array}{l}\text { Self- } \\
\text { Kindnes } \\
\mathrm{s}\end{array}$ & $\begin{array}{l}\text { Self } \\
\text { Judgeme } \\
\text { nt }\end{array}$ & $\begin{array}{l}\text { Commo } \\
\mathrm{n} \\
\text { Humanit } \\
\mathrm{y}\end{array}$ & $\begin{array}{l}\text { Isolatio } \\
\mathrm{n}\end{array}$ & $\begin{array}{l}\text { Mindfulne } \\
\text { ss }\end{array}$ & $\begin{array}{l}\text { Over- } \\
\text { Identificati } \\
\text { on }\end{array}$ \\
\hline \multirow[t]{3}{*}{ SAE } & $\begin{array}{l}\text { Pearson } \\
\text { Correlatio } \\
\mathrm{n}\end{array}$ & 1 & $.409^{* *}$ & -.236 & .073 & -.289 & $.386^{*}$ & $-.388^{*}$ \\
\hline & $\begin{array}{l}\text { Sig. (2- } \\
\text { tailed) }\end{array}$ & & .006 & .128 & .641 & .060 & .010 & .010 \\
\hline & $\mathrm{N}$ & 43 & 43 & 43 & 43 & 43 & 43 & 43 \\
\hline \multirow[t]{2}{*}{$\begin{array}{l}\text { Self- } \\
\text { Kindness }\end{array}$} & $\begin{array}{l}\text { Pearson } \\
\text { Correlatio } \\
\mathrm{n}\end{array}$ & $\begin{array}{l}.409^{*} \\
*\end{array}$ & 1 & $-.466^{* *}$ & $.531^{* *}$ & $-.326^{*}$ & $.728^{* *}$ & $-.418^{* *}$ \\
\hline & $\begin{array}{l}\text { Sig. (2- } \\
\text { tailed) }\end{array}$ & .006 & & .002 & .000 & .033 & .000 & .005 \\
\hline \multirow[t]{2}{*}{$\begin{array}{l}\text { Self } \\
\text { Judgement }\end{array}$} & $\begin{array}{l}\text { Pearson } \\
\text { Correlatio } \\
\mathrm{n}\end{array}$ & -.236 & $-.466^{* *}$ & 1 & .010 & $.588^{* *}$ & -.182 & $.692^{* *}$ \\
\hline & $\begin{array}{l}\text { Sig. (2- } \\
\text { tailed) }\end{array}$ & .128 & .002 & & .950 & .000 & .243 & .000 \\
\hline \multirow[t]{2}{*}{$\begin{array}{l}\text { Common } \\
\text { Humanity }\end{array}$} & $\begin{array}{l}\text { Pearson } \\
\text { Correlatio } \\
\mathrm{n}\end{array}$ & .073 & $.531^{* *}$ & .010 & 1 & .029 & $.688^{* *}$ & -.138 \\
\hline & $\begin{array}{l}\text { Sig. (2- } \\
\text { tailed) }\end{array}$ & .641 & .000 & .950 & & .853 & .000 & .378 \\
\hline
\end{tabular}

auto-eficacitate corelează puternic semnificativ cu dimensiune de selfkindness (bunătatea îndreptată către sine) Pearson Correlation $\mathrm{R}=.409^{* *}, \mathrm{p}=0.01$. și semnificativ statistic cu dimensiune de Mindfulness - Pearson Correlation $\mathrm{R}=$ $.386^{* *}, \mathrm{p}=0.05$. Este o relație indirectă, semnificativ statistic cu dimensiunea de Over-Identification (supra - identificare) Pearson Correlation $\mathrm{R}=.388^{*}, \mathrm{p}=0.01$. nesemnificativă statistic însă, cu Self Judgemen (auto-critica) R=-.236 și cu Isolation (izolarea) $\mathrm{R}=-.289$. Lipsit de relație statistică este și relația dintre SAE și Common Humanity (Umanintatea bazală) Auto-eficacitatea este în relație indirectă, 


\begin{tabular}{l|l|l|l|l|l|l|l|l}
\hline Isolation & $\begin{array}{l}\text { Pearson } \\
\text { Correlatio } \\
\mathrm{n}\end{array}$ & -.289 & $-.326^{*}$ & $.588^{* *}$ & .029 & 1 & -.214 & $.52^{* *}$ \\
\cline { 2 - 8 } & $\begin{array}{l}\text { Sig. (2- } \\
\text { tailed) }\end{array}$ & .060 & .033 & .000 & .853 & & .168 & .000 \\
\hline $\begin{array}{l}\text { Mindfulnes } \\
\mathrm{s}\end{array}$ & $\begin{array}{l}\text { Pearson } \\
\text { Correlatio } \\
\mathrm{n}\end{array}$ & $.386^{*}$ & $.728^{* *}$ & -.182 & $.688^{* *}$ & -.214 & 1 & -.297 \\
\cline { 2 - 8 } & $\begin{array}{l}\text { Sig. (2- } \\
\text { tailed) }\end{array}$ & .010 & .000 & .243 & .000 & .168 & & .053 \\
\hline $\begin{array}{l}\text { Over- } \\
\text { Identificati } \\
\text { on }\end{array}$ & $\begin{array}{l}\text { Pearson } \\
\text { Correlatio } \\
\mathrm{n}\end{array}$ & $-.388^{*}$ & $-.418^{* *}$ & $.692^{* *}$ & -.138 & $.592^{* *}$ & -.297 & 1 \\
\cline { 2 - 8 } & $\begin{array}{l}\text { Sig. (2- } \\
\text { tailed) }\end{array}$ & .010 & .005 & .000 & .378 & .000 & .053 & \\
\hline
\end{tabular}

**. Correlation is significant at the o.or level (2-tailed).

*. Correlation is significant at the 0.05 level (2-tailed).

\section{Relația auto-eficacitățiti și vârsta participanților}

Conform datelor rezultate scorurile de auto-eficacitate sunt influențate de vârsta persoanelor. Cele mai crescute scoruri la scala de evaluare a auto-eficacității au fost obținute de grupa de vârstă 51-6o de ani, iar cele mai scăzute scoruri au fost obținute de vârsta de grupă 20-30 de ani. Creșterea scorurilor la scala de autoeficacitate se face în mod progresiv de la vârstele tinere către vârstele mature.

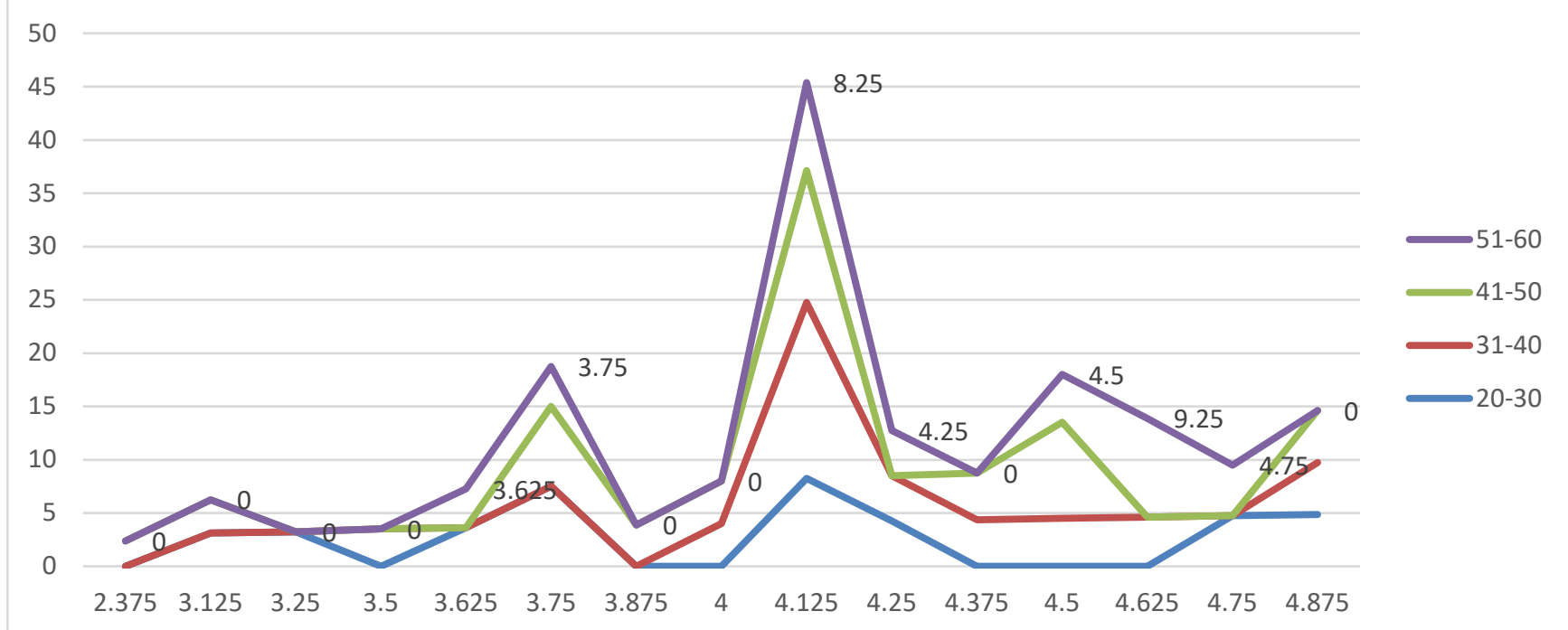

Figura nr 5- Rezultatele la scala de auto-eficacitate relaționate cu vârsta participanților la studiu.

Relația dintre auto-eficacitate și experiența profesională se păstrează ca și în cazul vârstei participanților. Cele mai crescute scoruri obținute prin instrumentul de evaluare a auto- eficacității sunt atribuite persoanelor care au o vechime în profesie de peste 15 ani, reliefate în graficul de mai jos prin culoarea orange (fig nr 6). Persoanele care au o vechime în profesie situată între 10-15 
ani au scoruri crescute la scala de autoeficacitate, iar terapeuții care sunt la început de carieră înregistrează o autoeficacitate mai scăzută.

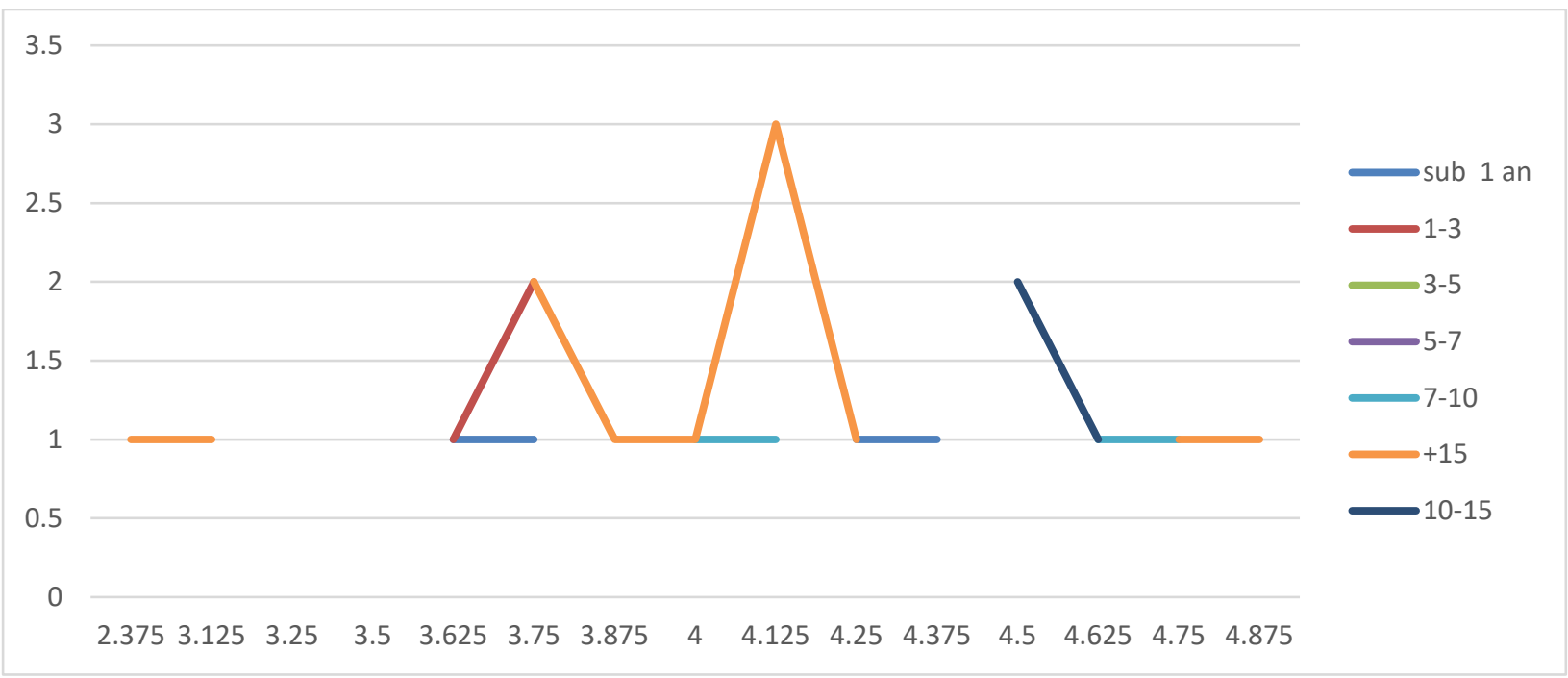

Figura nr.6- Distribuția scorurilor la scala de auto-eficacitate raportată la experiența profesională a terapeuților

Pe baza scorurilor medii obținute la scala de auto-eficacitate, în relație cu experiența profesională este indicată $\mathrm{o}$ raportare crescătoare de la debutul în profesie la experiența în profesie. Media cea mai mică o au terapeuții care au o vechime sub 1 an, $\mathrm{M}=3,8(\mathrm{SD} \pm .868)$, iar valoarea cea mare în perceperea auto-eficacității o au terapeuții cu peste 15 ani vechime, cu o $\mathrm{M}=4.59$ (SD \pm .536$)$. Interesant de observat este și faptul că în perioada de experiență profesională situată între 3-5 ani nivelul auto-eficacității percepute are valoare cea mai mică din plaja de experiență profesională $\mathrm{M}=3.68(\mathrm{SD} \pm .425)$.

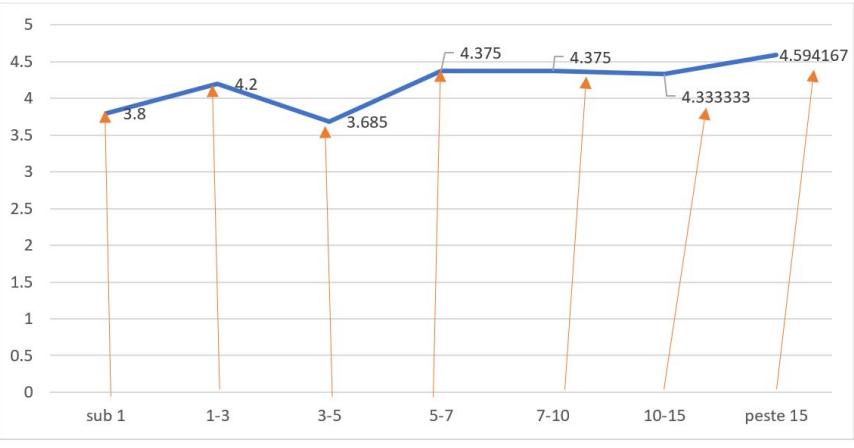

Figura $n r 7$ Rezultatele medii la SAC relaționate la experiența profesională a terapeuților

\section{Rezultatele oltitinute în relația dîntre auto- compasiune și vârstă paciențillor.}

Pe baza rezultatelor prezentate în graficul nr 5 se poate observa că cele mai crescute scoruri la scala de auto-compasiune o înregistrează vârstele înaintate, în intervalul de vârstă -51-6o de ani, cu o medie de $M=4,01$ urmată vârsta de 41-50 de ani, cu o medie de $M=3,90$. Cele mai mici valori înregistrate de terapeuți la scala de auto-compasiune aparține grupei de vârstă a terapeuților aflați între 20 și 30 de ani. 


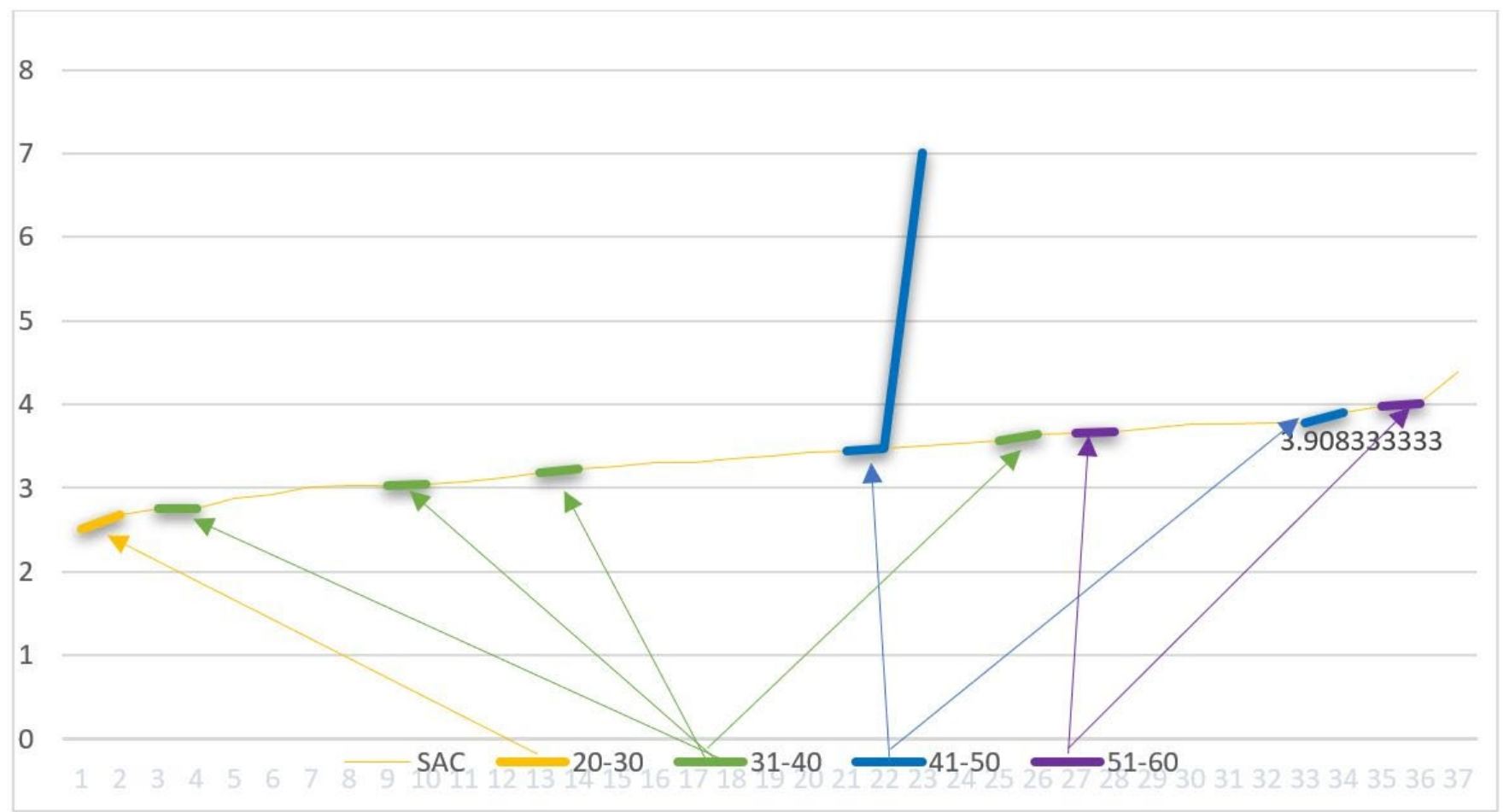

Figura nr 8 - Distribuția răspunsurilor la SAC relaționată la vârsta participanților Cel mai mare nivel al SCS este între 40-50 ani

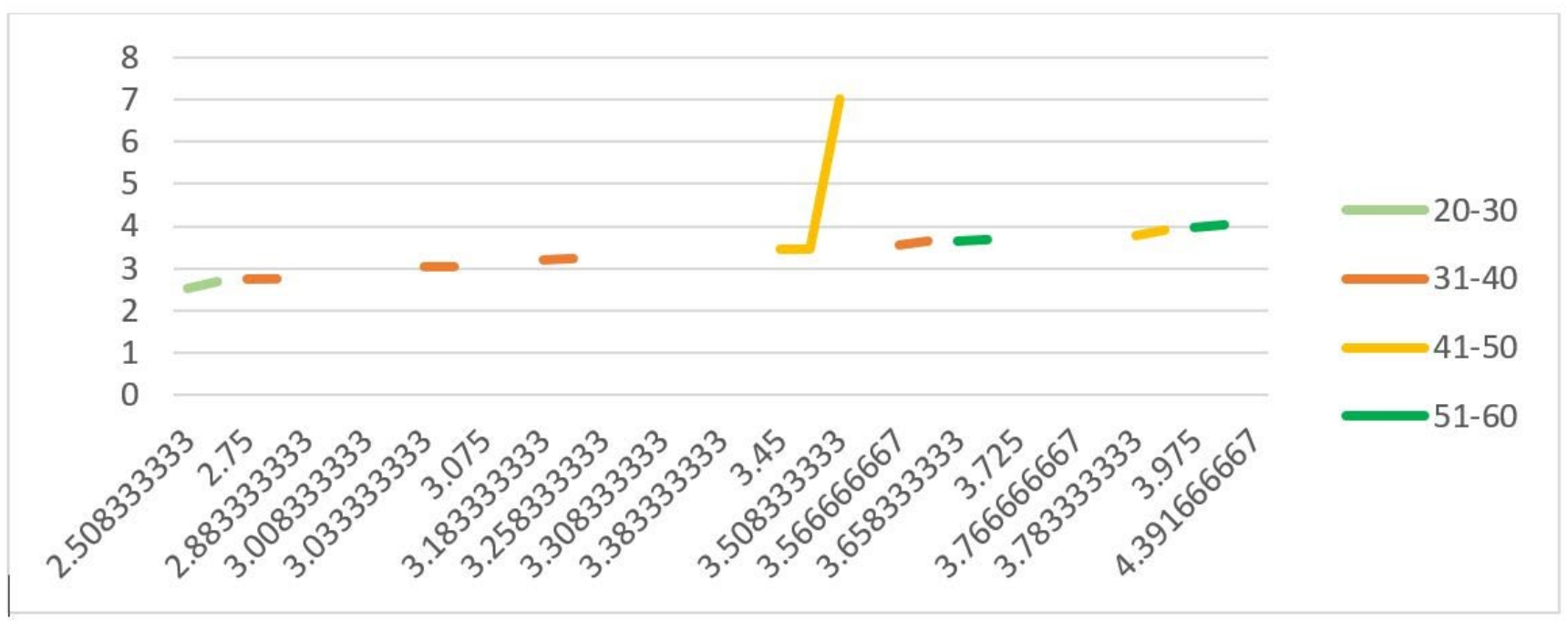

Figura nr 9 - Distribuția răspunsurilor la scala de SAC în funcție de vârsta participanților 
Relația se păstrează și în cazul analizei dintre rezultatele obținute la scala de auto-compasiune și experiența profesională a psihoterapeuților. La începutul activării în profesie terapeuții sunt mai puțin compasivi cu propria lor persoană, apoi se remarcă un trend ascendent pentru ca undeva în perioada 710 ani să se observe o scădere a mediei, iar apoi o creștere a nivelului de autocompasiune către valori mari

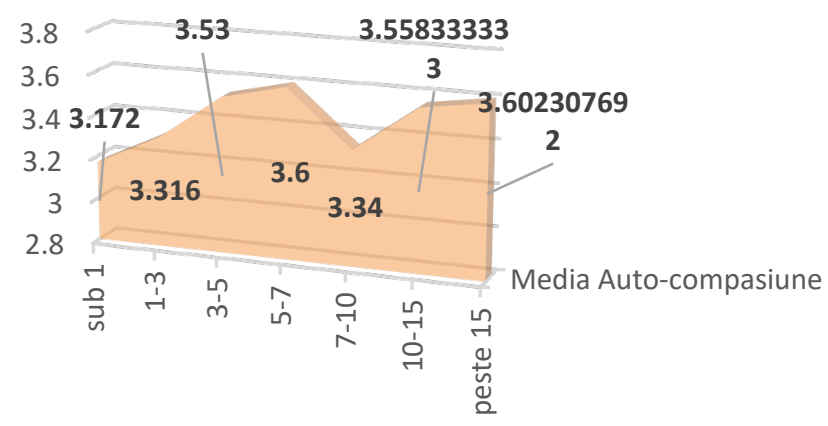

Figura nr 10 - Media răspunsurilor la SAC raportată la experiența profesională

\section{Discuții}

În cazul categoriei profesionale investigate, cea a terapeuților, s-a constatat că există relații între cele două constructe, cel de auto-eficacitate, conform încadrării conceptuale definite de Albert Bandura (Bandura, 1997), operaționalizate prin scala propusă de Chen și colaboratorii (Chen et al., 2001) și auto-compasiunea, așa cum a fost încadrată conceptual și cuantificată de Kristin Neff (K. D. Neff et al., 2020). Această relație are implicații profesionale, mai ales în situații stresante, atunci când apelul la resursele personale este ridicat.
Percepția stresului raportată la profesia de terapeut și implicit necesitatea monitorizării surselor stresante au fost subliniate cu mulți ani în urmă (Farber, 1983; Hellman et al., 1987) și continuă să fie o preocupare actuală. Terapeuții trebuie să fie empatici și compasivi prin natura profesiei pe care o exercită, dar în același timp să fie alerți și sensibili la acele surse particulare de stres care îi afectează și la natura relației terapeutice, să fie orientați către protecția propriei persoane și să își permită să manifeste grijă și compasiune față de persoana lor.

Rezultatele prezentului studiu converg $\mathrm{cu}$ alte rezultate publicate anterior. Spre exemplu într-un studiu realizat de Medeiros și colaboratorii (Medeiros \& Prochaska, 1988) între strategiile de coping pe care psihoterapeuții le foloseau pentru a face față stresului provenit din relația terapeutică se numărau autoreevaluarea și gândirea pozitivă și expectativă, perseverența și optimismul, căutarea liniștii interioare etc. Aceste modalități de coping erau subliniate de către autorii studiului ca fiind eficient și ca fiind folosite de către psihoterapeuții care se auto-percepeau ca având succes. Corelând aceste indicații cu rezultatele studiului prezent, putem constata suprapuneri conceptuale între anumite dimensiuni din scala de auto-compasiune, spre exemplu mindfulness și căutarea păcii interioare din studiu indicat (Medeiros \& Prochaska, 1988), sau între autoeficacitate și succesul în profesie.

Rezultatele obținute la scala de autoeficacitate în cazul terapeuților sunt importante prin prisma implicațiilor. Pentru prezentul studiu terapeuții au obținut scoruri relativ crescute, dar au fost 
și valori minime care indică o percepție redusă a propriei eficacități. În relație cu scala de auto-eficacitate un semnal de alarmă trebuie tras în condițiile existenței unor scoruri scăzute, întrucât acestea indică o percepție scăzută a propriei eficacități, iar în relațiile cu beneficiarii acest lucru are implicații terapeutice. Atunci când terapeutul nu are încredere în propria eficiență, posibilitate ca neîncrederea să se transmită și asupra procesului terapeutic este crescută. Important este însă faptul că rezultatele obținute la scala de auto-eficacitate se relaționează cu vârsta terapeuților, dar și cu experiența profesională. Acest lucru poate fi interpretat prin experiența pe care terapeuții o acumulează. Cu cât au mai multă experiență de viață, și presupunând profesională, terapeuții au sentimente de auto-eficacitate mai crescute.

Analizarea relația dinte SAE si nivelul profesional necesită o anumită atenție. Vedem că la începutul profesiei scorurile de auto-eficacitate sunt mai scăzute, urmând ca pe măsura acumulării de experiență să se fie obținute scoruri mai crescute. Dar interesant este faptul că în primele luni de profesie terapeuții se percep foarte eficienți, iar după primul an se observă o scădere a scorului de autoeficacitate. Acest lucru poate fi explicat prin faptul că la începutul carierei profesionale încrederea în capacitățile proprii este crescută, dar după primul an de profesie aceasta începe să crească. Totuși pe măsură ce se înaintează, la un moment dat auto-eficacitatea percepută începe să fie chestionată, o explicație putând să fie găsită în faptul că în acel interval terapeuții s-au putut bucura și de reușite, dar și de eșecuri în profesie.
Totuși, după ani de experiență profesională, viziunea asupra capacităților proprii începe să crească și să continue un trend ascendent.

Rezultatele obținute la scala de autocompasiune potrivesc și se suprapun $\mathrm{cu}$ cele obținute la scala de auto-eficacitate. Rezultatele converg cu cele obținute de cercetările anterioare asupra autocompasiunii (K. Neff, 2003). Dimensiunile cu valență negativă, auto-critica, izolarea și supra-identificarea sunt la praguri scăzute, iar cele cu valență pozitivă precum umanitatea, auto-compasiunea și auto-bunătatea sunt la nivel superior pe grafic. Acest lucru poate avea impact asupra funcționalității ca individ și ca terapeut. În profesiile care presupun prin natura lor interacțiune umană, empatie și dăruire, un factor de risc îl reprezintă epuizarea resurselor psihice și apariția stării de burn-out. Dacă terapeuții se lasă în afara cercului îngrijirii, oboseala emoțională nu întârzie să se manifeste, iar epuizarea personală apare ca o consecință firească. Printre factori de risc se numără neajutorare și sentiment de ineficiență, iar printre factorii protectivi se numără practicarea tehnicilor de îngrijire și recuperare personală și petrecerea timpului cu prietenii și familia (Zur, 2021). Într-un studiu (Bruschini et al., 2018) desfășurat pe terapeuți din domeniul reabilitării și îngrijirii paliative, s-a observat că profesioniștii în reabilitare prezintă un risc ridicat de epuizare. Există mecanisme comune care stau la baza epuizării în diferitele grupuri profesionale investigate. Concret, factorii de risc identificați au fost epuizarea emoțională $32 \%$, depersonalizarea $13 \%$ și lipsa mulțumirii personale $9 \%$. Similar 
rezultatelor din studiul prezent, în studiul italian (Bruschini et al., 2018) nu s-au constat diferențe de la nivelul factorilor de risc între diferite categoria de terapeuți.

Auto-compasiunea are scoruri mai crescute pe măsură ce terapeuții înaintează în vârstă și în experiența profesională și scoruri mai scăzute la începutul carieri. $\mathrm{O}$ explicație poate consta în faptul că pe măsura dobândirii experienței terapeuții înțeleg că nevoia de auto-protecție este reală, și că izolarea și autocritica funcționează împotriva propriei persoane. Ei înțeleg că pentru a fi eficienți trebuie să fie în egală măsură compasivi cu beneficiarii, dar și cu ei însuși. Rezultatele acestui studiu sunt în relație cu cele identificate de alte studii (Vivino et al., 2009) care susțin că dincolo de empatie este compasiunea și că aceasta ajută la o abordare mai eficientă și lipsită de prejudecăți. Auto-compasiunea presupune și apelul la tehnicile mindfulness, tehnici dovedite utile în psihoterapie (Jennings \& Apsche, 2014; Linehan, 1993) În studiul de față terapeuții au obținut scoruri crescute la dimensiunea de mindfulness, iar acest lucru se poate constitui într-un factor de protecție personală.

\section{Concluzii}

Cele două concepte discutate, cel de autocompasiune și de auto-eficacitate sunt importante în relație cu anumite categorii profesionale și sub auspiciile unor situații considerate stresante și cu încărcătură emoțională crescută. Profesia terapeuților constituie o categorie profesională care se bazează pe compasiune și emoții, iar percepția propriei eficacități influențează actul terapeutic. Studiul de față a a reușit să surprindă modul în care se relaționează auto-compasiune și auto-eficacitatea în cazul terapeuților, dar și relevanța vârstei și a experienței profesionale față de aceste concepte cu implicații și aplicabilitate nu doar teoretică, ci și practică. În final pot fi subliniate câteva aspecte conclusive: (1)Terapeuții tind să aibă valori mari în evaluarea auto-eficacității; (2)Terapeuții tind să aibă valori crescute ale autocompasiunii; (3)Terapeuții tind să aibă nivel ridicat de auto-compasiune și scăzut în cazul auto-criticii așa cum indică subscalele de auto-compasiune; (4) Există o relație directă între auto-eficacitate și auto-compasiune; (5) Terapeuții care au nivel de auto-compasiune crescut au și nivel de auto-eficacitate ridicat, adică au nivel de performanță mai crescut; (6)Nivelul de auto-eficacitate este influențat de vârstă și experiența profesională. (7) Nivelul de autocompasiune este influențat de vârstă și experiența profesională

\section{Bibliografie}

Bandura, A. (1997). Self-efficacy: The exercise of control. Freeman.

Betz, N. E., \& Klein, K. L. (1996). Relationships among measures of career self-efficacy, generalized selfefficacy, and global self-esteem. Journal of Career Assessment. https://doi.org/10.1177/1069072796004 $\underline{00304}$

Bruschini, M., Carli, A., \& Burla, F. (2018). Burnout and work-related stress in Italian rehabilitation professionals: A comparison of physiotherapists, speech therapists and occupational therapists. Work, 59(1), 121-129. https://doi.org/10.3233/WOR-172657 
Chen, G., Gully, S. M., \& Eden, D. (2001). Validation of a New General SelfEfficacy Scale. Organizational Research Methods, 4(1), 62-83. https://doi.org/10.1177/10944281014100 4

Dijkstra, A., \& De Vries, H. (200o). Selfefficacy expectations with regard to different tasks in smoking cessation. Psychology and Health, 15(4), 501-511. https://doi.org/10.1080/088704400084 02009

Farber, B. A. (1983). Psychotherapists' perceptions of stressful patient behavior. Professional Psychology: Research and Practice, 14(5), 697-705. https://doi.org/10.1037/07357028.14.5.697

Gilbert, P. (2020). Compasiunea și mintea umană. Curtea Verche Publishing.

Hellman, I. D., Morrison, T. L., \& Abramowitz, S. I. (1987). Therapist experience and the stresses of psychotherapeutic work. Psychotherapy, 24(2), 171-177. https://doi.org/10.1037/hoo85701

Jennings, J. L., \& Apsche, J. A. (2014). The evolution of a fundamentally mindfulness-based treatment methodology: From DBT and ACT to MDT and beyond. International Journal of Behavioral Consultation and Therapy, 9(2), $1-3$. https://doi.org/10.1037/ho10099o

Linehan, M. (1993). Skills training manual for treating borderline personality disorder. Guilford Press.

Medeiros, M. E., \& Prochaska, J. O. (1988). Coping Strategies That Psychotherapists Use in Working With
Stressful Clients. Professional Psychology: Research and Practice, 19(1), 112-114.

https://doi.org/10.1037/07357028.19.1.112

Neff, K. (2003). Self-Compassion: An Alternative Conceptualization of a Healthy Attitude Toward Oneself. Self and Identity, 2(2), 85-101. https://doi.org/10.1080/1529886030903 $\underline{2}$

Neff, K. (2021). Self-Compassion. https://self-compassion.org/

Neff, K. D., Tóth-Király, I., Knox, M. C., Kuchar, A., \& Davidson, O. (2020). The Development and Validation of the State Self-Compassion Scale (Longand Short Form). Mindfulness. https://doi.org/10.1007/s12671-02001505-4

SPARQtools. (2021). New General SelfEfficacy Scale | SPARQtools. http://sparqtools.org/mobilitymeasure/new-general-self-efficacyscale/\#all-survey-questions

Tăut, D., \& Băban, A. (2008). Examination of the relationship between selfregulatory strategies and healthy eating patterns in coronary heart disease patients. The relevance of compensatory health beliefs. Cogniţie Creier Comportament, 12(2), 219-231.

Vivino, B. L., Thompson, B. J., Hill, C. E., \& Ladany, N. (2009). Compassion in psychotherapy: The perspective of therapists nominated as compassionate. Psychotherapy Research, $\quad$ 19(2), 157-171. https://doi.org/10.1080/1050330080243 $\underline{0681}$ 
Zur. (2021). Therapist Burnout: Facts, Causes and Prevention. https://www.zurinstitute.com/clinicalupdates/burnout-therapists/

\section{Disclaimer}

Autorii indică faptul că nu există conflicte de interese în derularea și publicarea prezentului studiu. Rezultate parțiale și preliminarii au fost prezentate sub formă de lucrare orală la Congresul Național de Psihiatrie - Ediția XIII.

\section{Acknowledgements:}

This work was supported by the grant Partnership for the transfer of knowledge in biogenomics applications in oncology and related fields BIOGENONCO, Project co-financed by FEDR through Competitiveness Operational Programme 2014-2020, contract no. 10/01.09.2016.

1*. Asistent universitar dr. Disciplina de Psihologie Medicală, Universitatea de Medicină și Farmacie „Iuliu Hațieganu” Cluj-Napoca,

Email: raluca.trifu@umfcluj.ro

${ }^{2 *}$ Asistent universitar dr, Disciplina Psihologie Medicală, Universitatea de Medicină și Farmacie „Iuliu Hațieganu” Cluj-Napoca, medic specialist psihiatrie pediatrică. Autor corespondent.

\section{Email:bogdana.miclea@umfcluj.ro}

bogdanamilea@yahoo.ro

3 Șef de lucrări disciplina Psihologie medicală, Universitatea de Medicină și Farmacie „Iuliu Hațieganu” Cluj-Napoca, medic specialist psihiatrie pediatrică

4 Psiholog, Cabinet individual de Psihologie Smaranda Pușcașu

5 Conferențiar, Departamentul de Psihopedagogie Specială, Facultatea de Psihologie și Științele Educației, UBB Cluj

*Corespondent
6. Conferențiar, Disciplina de Psihologie Medicală, Universitatea de Medicină și Farmacie „Iuliu Hațieganu” Cluj-Napoca. Șef. Clinică Psihatrie nr. III. Spitalul Clinic Județean. 


\title{
Impactul managementului disfagiei asupra calității vieții persoanelor cu accident vascular cerebral
}

\author{
Raluca-Mariana POPA ${ }^{1}$
}

\begin{abstract}
The objective of the following research is the investigation of the impact that management of dysphagia has upon quality of life in persons with neurological pathology of vascular cerebreal attack type. The group of participants in this study has 6 members with ages between 34 and 69, all suffering from a neurological pathology of VCA type or cranio-cerebreal trauma with direct implications on the swallowing process. This paper used case study methode as experimental design, the goal being to detect the impact that speach therapy has on the dysphagia, in the context of safety and quality of life. A series of instruments regarding clinical evaluation of dysphagia and quality of life in the context of VCA and dysphagia where been translated and adapted in the fallowing research.
\end{abstract}

Keywords: dysphagia, life quality, celebral stroke, speech language therapy

\section{Introducere}

Cercetarea de față și-a propus sondarea impactului managementului disfagiei asupra calității vieții persoanelor cu accidente vasculare cerebrale. Această cercetare a fost realizată pe un microeșantion de șase subiecți aplincându-se o varietate de teste ce sondează gradul disfagiei și impactul terapiei logopedice asupra calității vieții. Evaluarea acestui impact a fost surprins $\mathrm{cu}$ ajutorul următoarelor teste: Stroke Specific Quality of life Scale (SS-QOL); Barthel Index; Swalloing Quality of Life Questionnaire (SWAL-QOL); Water swallow test; Modified Wather swallow test; Instrument de evaluare a deglutiției (IED-10); Instrument de evaluare clinică a deglutiției; Disphagia handicap Index (DHI); Fork Drip test; Fork Pressure Test and Spoon Pressure Test. Pacienții care au suferit un accident vascular cerebral, ce sau sondat $\mathrm{cu}$ patologii motorii asociate $\mathrm{cu}$ tulburări de deglutiție, impactul resimțit de persoană este mult mai mare, adesea acesta experimentând teamă de a mânca, de a înghiții, anxietate mărită pe tot parcursul alimentării și al hidratării, uneori mergând până la refuzul complet de alimente și depresie. Nu trebuie să uităm și de aspectul social și de interacțiune pe care îl exercită rutina mesei. Prin urmare demersul terapeutic și de reabilitare trebuie să țină seama de dorința de alimentație, durata alimentației, frecvența simptomelor, funcția socială, selecția alimentelor, comunicarea, frica, sănătatea mentală, nevoia de somn și oboseală (Ayres, A și colab., 2016).

Deglutiția sau înghițirea este acel proces mecanic voluntar și reflex în care sunt implicate peste 50 de nervi și mușchi, prin care alimentele sunt împinse de la nivelul cavității bucale, în faringe, apoi în esofag având drept destinație finală stomacul (Jones, B.,2003.) Prin urmare înghițirea cuprinde totalitatea activităților motorii ce asigură transportul bolului alimentar din cavitatea bucală în stomac, proces ce 
constă într-un lanț de mișcări voluntare și reflexe. În strânsă legătură cu structura anatomică care este implicată în actul deglutițional cercetătorii vorbesc și clasifică, în literatura de specialitate, deglutiția în trei faze principale: faza orală, faza faringiană și faza esofagiană. Orice perturbare ce poate surveni în desfășurarea acestui proces, fie că este vorba de faza orală, faringiană sau esofagiană a deglutiției, determină dificultăți în înghițire, regăsite în literatura de specialitate sub denumirea de disfagie, cu un impact mai mic sau mai mare asupra sănătății individului.

Conform cercetărilor efectuate de Bhattacharyya în 2014 se arată că la nivelul USA unul din 25 de adulți se confruntă cu tulburări de înghițire. Studiile epidemiologice indică faptul că disfagia are o prevelență mai ridicată în cadrul vârsnicilor (Cabré, M. și colab., 2014). Chiar dacă există mai multe grade de dificultate a disfagiei, statisticile de sănătate publică din Regatul Unit, declară în 2011 că aproximativ 11\% din populația acesteia este afectată de disfagie. $\mathrm{O}$ altă statistică oferită de către World Gastroenterology Global Guidelines (2014) ne arătă că disfagia afectează în proporție de $40-70 \%$ pacienții post Accident Vascular Cerebral, 6o-80\% din pacienții cu condiții meurogenerative, peste $13 \%$ pacienții cu vâstă de peste 65 de ani, 51\% din persoanele instituționalizate în centre de îngrijire permanentă, și $60-75 \%$ din pacienții ce au urmat proceduri de radioterapie post cancere de gât și cap (Ronkainen, J. și colab. 2007).

Etiologia diagnostică a disfagiei este una complexă și cuprinde foarte multe patologii, prin urmare și tratamentul acesteia depinde de cauza disfagiei, de simptomale asociate și timpul de probleme de deglutiție pe care pacientul le acuză. Managementulul disfagiei trebuie să se bazeze pe rezultatele evaluării clinice și să țină seamă de o serie de factori cu privire la starea generală de sătătate a pacientului, a prognosticului bolii, dar să includă și factori ce țin de starea și diagnosticul persoane, de nivelul intelectual al acesteia, de situația socială, de valorile culturale, satrea economică, motivația și alegerile personale.

30\%-65\% dintre persoanele care au suferit un accident vascular cerebral prezintă simptome disfagice, ce se ameliorează cu precădere în prima lună post AVC, însă la un procent reprezentativ de cazuri, aceste simptome putând persista și până la 6 luni (Norine, C. și colab., 2009). În etapa acută a AVC în proporție de 40-60\% dintre pacienți în urma simptomelor disfagice se confruntă cu malnutriție și scădere în greutate prin reducerea aportului nutritiv și hidric. Din cauza problemelor survenite în urma AVC-ului pacientul prezintă tulburări de conștiință, deficite motorii, paralizii ale structurilor implicate în deglutiție, agnozie, apraxie, etc toate cu impact direct asupra alimentației acestuia, stare care se prelungește pe perioada spitalizării prelungite, a recuperării, necesitând asistență îndelungată și costuri ridicate. De asemenea un risc marcant la această categorie de pacienți o reprezintă pneumonia de asipirație a cărei pondere este de aproximativ 35\% din decesele postAVC (Livia, S, și colab, 2012). Complicațiile ce apar în urma AVC-ului și a disfagiei au un impact negativ asupra bunăstării fizice, psihice și sociale a pacienților, asupra calității vieții 
pacienților, cât și asupra familiei și aparținătorilor acestora (Carnaby-Mann, G., Lenius, K., Crary, M., 2007).

Clasificarea internaţională a funcţionării, dizabilităţii şi sănătăţii (CIF, 2004) încadrează termenul de calitate a vieții într-o dimensiune bio-psiho-socială, punând accent pe limitările și capacitățile individului de a participa în diverse domenii existențiale. De aceea calitatea vieții este asociată frecvent cu o serie de constructe de satisfacție a vieții din domeniul social, fizic/motric, emoțional și cognitiv (McKevitt C, 2003), ea putând fi monitorizată constant pe parcursul procesului recuperator al deficitelor funcționale, cognitive și sociale ale pacientului.

În sondarea calității vieții persoanelor cu disfagie ca urmare a unui accident vascular trebuie analizate mai multe domenii, precum dorința de alimentație: durata alimentației; frecvența simptomelor; funcția socială; selecția alimentelor; comunicarea; frica; sănătatea mentală: nevoia de somn și oboseală (Ayres, A și colab., 2016).

\section{Obiective}

Obiectivele specifice ale aceste cercetări vizează:

- Traducerea și adaptarea chestionarelor de evaluare a calității vieții la persoanele cu accident vascular cerebral cu disfagie - Stroke Specific Quality of life Scale (SS-QOL) și Swallowing Quality of life questionaire (SWAL-QOL);

- Elaborarea și implementarea planului de managemet și de reabilitare a abilităților de deglutiție;
- Evaluarea impactului pe care îl are programul terapeutic asupra calității vieții persoanelor ce AVC;

- Analiza calitativă a datelor obținute în urma aplicării instrumentelor de evaluare prin analiza indicilor, a simptomatologiei persistente sau remise, a frecvenței simptomatologiei.

\section{Ipotezele cercetări}

Impotezele de la care s-a plecat sunt:

- Se vor înregistra diferențe semnificative în scăderea frecvenței simptomatologiei disfagiei ca urmare a parcurgerii programului terapeutic, generând o creștere semnificativă a calității vieții acestora.

- $\quad$ In ceea ce privește selecția dietei și consistenței alimentare se vor înregistra diferențe semnificative în urma parcurgerii terapiei deglutiționale;

- Un nivel semnificativ al deficienței înregistrate va fi un predictor al nivelului de percepție a calității vieții.

\section{Participanți}

La acest studiu au participat 6 subiecți ce au fost internați în cadrul Spitalului de Recuperarea Polaris Medical, fiind internați pe secția de neurologie ca urmare a unei patologii neurologice de tipul accidentului vascular cerebral ischemic sau hemoragic după caz. Înaintea începerii procedurilor de evaluare pacienții au fost informați despre această cercetare, oferindu-și acordul de participare la acesta. Media de vârstă la momentul internării paciențiilor a fost de cinzeci și șapte de ani și cinci luni, cel mai învârstă având șaizeci și nouă de ani și zece luni, iar cel mai tânăr participant având treizeci și nouă de ani și nouă luni. Având în vedere 
durata de timp de la accidentul vascular cerebral, durata medie a bolii a acestor pacienți a fost de două luni, cea mai recentă durată fiind de o lună, iar cea mai îndepărtată fiind de opt luni. Nivelul de educație a subiecțiilor surprinși în studiu au fost în proporție de 50\% aveau studii superioare, iar 50\% aveau studii medii. Dintre cei șase participanți la studiu patru au fost bărbați și două femei.

Tabel. I. Caracteristici ale participaților în

\begin{tabular}{|c|c|c|c|c|c|}
\hline & $\begin{array}{l}\text { Vârs } \\
\text { tă }\end{array}$ & $\begin{array}{l}\text { Gen } \\
\text { ul }\end{array}$ & Studii & $\begin{array}{l}\text { Dura } \\
\text { ta de } \\
\text { la } \\
\text { AVC }\end{array}$ & $\begin{array}{l}\text { Modul } \\
\text { de } \\
\text { hrănire }\end{array}$ \\
\hline C. & 54 și & $\bar{M}$ & Medii & 1 & tub \\
\hline M & 61 & & & luna & $\begin{array}{l}\text { nazogast } \\
\text { ric }\end{array}$ \\
\hline I.V. & $\begin{array}{l}\text { 6o și } \\
21\end{array}$ & F & Medii & $\begin{array}{l}4 \\
\text { luni }\end{array}$ & $\begin{array}{l}\text { oral- } \\
\text { consisten } \\
\text { ță } \\
\text { modificat } \\
\breve{a}\end{array}$ \\
\hline C.C & $\begin{array}{l}34 \text { și } \\
91\end{array}$ & M & $\begin{array}{l}\text { Superio } \\
\text { are }\end{array}$ & $\begin{array}{l}8 \\
\text { luni }\end{array}$ & $\begin{array}{l}\text { gastrosto } \\
\text { mă și } \\
\text { traheosto } \\
\text { mă }\end{array}$ \\
\hline $\begin{array}{l}\text { D. } \\
\text { O. }\end{array}$ & $\begin{array}{l}69 \text { și } \\
101\end{array}$ & $\mathrm{M}$ & $\begin{array}{l}\text { Superio } \\
\text { are }\end{array}$ & $\begin{array}{l}2 \\
\text { luni }\end{array}$ & $\begin{array}{l}\text { sondă } \\
\text { nazogast } \\
\text { rică }\end{array}$ \\
\hline $\begin{array}{l}\text { G. } \\
\text { R. }\end{array}$ & $\begin{array}{l}56 \text { și } \\
11\end{array}$ & F & Medii & $\begin{array}{l}3 \\
\text { luni }\end{array}$ & $\begin{array}{l}\text { dificultăt } \\
\text { i lichide }\end{array}$ \\
\hline P.E & $\begin{array}{l}67 \text { și } \\
31\end{array}$ & $\mathrm{M}$ & $\begin{array}{l}\text { Superio } \\
\text { are }\end{array}$ & $\begin{array}{l}4 \\
\text { luni }\end{array}$ & $\begin{array}{l}\text { dificultăț } \\
\text { i pastile, } \\
\text { lichide }\end{array}$ \\
\hline
\end{tabular}

Participanții la acest studiu au fost selectați în baza următoarelor criterii: 1) patologie survenită după accident vascular cerebral; 2) prezența tulburărilor de deglutiție, 3) durata de spitalizare de minim 4 săptămâni. De asemenea, au existat o serie de criterii de excludere din studiu care au ținut cont de: a) pacienții cu tulburări de limbaj receptiv și expresiv; b) pacienții cu deficiență de auz care întâmpinau dificultăți în înțelegerea programului de intervenție și c) pacienții cu demență. Informațiile au fost obținute în baza dosarului medical al pacientului, a discuțiilor din cadrul echipei multișciplinare și a interviului $\mathrm{cu}$ pacientul.

\section{Instrumente utilizate}

În cadrul acestei lucrări de cercetare au fost utilizate următoarele instrumente de evaluare și screening:

-Stroke Specific Quality of life Scale (SSQOL);

- Barthel Index; Swalloing Quality of Life Questionnaire (SWAL-QOL);

-Water swallow test; Modified Wather swallow test;

-Instrument de evaluare a deglutiției (IED-10);

-Instrument de evaluare clinică a deglutiției;

- Disphagia handicap Index (DHI);

-Fork Drip test;

-Fork Pressure Test and Spoon Pressure Test.

$\mathrm{O}$ parte din aceste teste au evaluat calitatea vieții ca urmare a accidentului vascular cerebral și a disfagiei, pe când o altă partea au evaluat gradul de afectare și dizabilitate a persoanei precum este indexul Barthel, iar restul au avut ca scop evaluarea statusului actual anatomic și funcțional al deglutiției, precum și metode standardizate de modificare a consistenței alimentare. Toate aceste instrumente de evaluare și diagnostic au fost aplicate în cadrul cercetării de două ori, la începutul și la finalul programului terapeutic. 


\section{Metodologie}

Cercetarea de față a fost realizat în cadrul Spitalului de Recuperare Polaris Medical. Pentru început după procedura de internare pacientul a fost informat de existența acestei cercetări și de posibilitatea participării la acesta. După acordul informat obținut de la fiecare pacient în parte, pacientul a fost evaluat și testat cu instrumetele pe care le-am menționat în subcapitolul anterior. Procedura de testarea s-a realizat pe de o parte în cabinetul logopedului sau în salonul fiecărui pacient după caz, procedura realizându-se pe parcursul primei ședințe de terapie ce a durat 50 de min, organizată sub forma unui interviu semistructurat. Logopedul a citit itemii și răspunsurile fiecărui instrument pentru fiecare pacient, pentru a minimiza efectul nivelului scăzut de educație sau a acuității vizuale scăzute, asigurându-se astfel o înțelegere corectă a chestionarelor, eliminând răspunsurile false datorate de lipsa înțelegerii a acestuia. Această procedură s-a realizat pentru toți pacienții. Colectarea datelor a avut loc din martie până în luna august 2019.

În baza rezultatelor surprinse prin intermediul testelor aplicate pentru fiecare pacient în parte s-a realizat un program de intervenție logopedică, ce a constat în 5 ședințe pe săptămână de 40 de minute pe o durată de 4 săptămâni. Numărul total de ședințe realizate cu fiecare pacient în parte au fost de 20 . Prima și ultima ședință a perioadei de cercetare au fost destinate pentru etapa de evaluare și aplicare a testelor și chestionarelor selectate. Cea de-a doua ședință de terapie a avut drept scop informarea pacientului despre programul terapeutic, modul în care va fi acesta aplicat și frecvența exercițiilor, informații despre selecția alimentelor, durata mesei, reguli și postura din timpul mesei, reguli de igienă orală etc. Ședințele 3-17 s-au concentrat cu precădere pe implementarea planului recuperator al disfagiei $\mathrm{cu}$ monitorizarea atentă a modificărilor ce survin și a reglării consitenței alimentare în raport cu fiecare stadiu recuperator.

\section{Panul terapeutic}

În baza informațiilor extrase în urma evaluării și a investigațiilor clinice, s-a întocmit fiecărui pacient în parte un program terapeutic personalizat ce a constat în trei faze: (a). Terapie indirectă (în cadrul acestei faze s-au realizat o serie de tehnici și exerciții specifice de antrenare a structurilor anatomice implicate în deglutiție), (b.) O fază ce a constat în aplicarea unor manevre compensatorii și tehnici directe de antrenare a înghițirii; iar cea de treia fază (c). a constat în terapia directă - prin administrarea alimentelor pe cale orală utilizându-se tehnici de modificare a consistenței alimentare.

Terapie indirectă s-a concentart de o serie de tehnici și exerciții specifice terapiei indirecte a disfagiei:

-Exerciții pentru antrenarea musculaturii gâtului:

-Exerciții pentru coordonarea și motricitatea buzelor - facilitează abilitatea pacientului de a menține lichidele și alimentele în cavitatea bucală;

-Exerciții pentru coordonarea și motricitatea obrajilor- ușurează rotația 
bolului alimentar în cadrul cavității bucale și menținerea acestuia.

- Exerciții pentru coordonarea și motricitatea mandibulei- facilitează ingerarea și mușcarea alimentelor, jucând un rol activ în procesul masticator. Mai mult îmbunătățește deschiderea sfincterului esofagian superior în timpul deglutiției, fiiind recomandat la pacienții cu dificultăți în ridicarea hioidului și /sau deschiderea inadecvata a sfincterului esofagian superior.

-Exerciții pentru coordonarea și motricitatea limbii- îmbunătățesc controlul limbii în manipularea și formarea bolului alimentar, a masticației și a propulsiei bolului spre faringe; creșterea masei musculare; creșterea presiunii înghițirii; diminuarea aspirației

-Exerciții pentru coordonarea și motricitatea vălului palatin îmbunătățește rididarea și sigilarea cavității nazale în timpul înghițirii:

-Exerciții pentru coordonarea și motricitatea faringelui:

-Exerciții pentru coordonarea și motricitatea laringelui;

-Exercițiul Shaker

Manevre compensatorii și tehnici directe de antrenare a înghițirii care au fost utilizat sunt:

-Aplecarea/flexia/înclinarea bărbiei în timpul înghițirii

- Rotația capului spre partea afectată

-Înclinarea capului spre partea sănătoasă

-Deglutiția supragolică

- Manevra Mendelsohn

-Înghițirea cu efort
- Tehnica Masako

- Tehnica Lee Silverman

\section{Studiu de caz}

\section{Date personale}

C.M. în vârstă de 54 de ani și 6 luni, a fost transferat în cadrul clinicii noastre în martie 2019 ca urmare a unui accident vascular cerebral ischemic pseudobulbar de $4 \mathrm{~mm}$, apărut în aprilie. Pacientul are asociat în istoricul medical hipertensiune arterială grad II, fără ateromatoză carotidiană, nefiind cunoscut cu alergii la diverse medicamente sau compuși chimici, nu prezintă traheostomizare. Pacientul prezintă sondă nazogastrică de aproximativ o lună de la accidentul vascular cerebral, ca urmare a unui episod de sufocare prin înnec cu lichide.

\section{Demersul evaluativ}

Evaluarea pacientului C.M. a debutat la data de 19.05.2019, o dată cu internarea acestuia pe secția de neurologie din cadrul clinicii noastre, atitudinea și comportamentul acestuia față de acest demers fiind unul receptiv și de cooperare cu echipa medicală. În baza interviului realizat cu C.M. și a aplicării instrumentelor de diagnostic acesta acuză imposibilitatea de a înghiți lichide, alimente solide, aceeași atitudine fiind prezentă și față de propriile secreții, pe care le elimină constant pe timpul celor 24 ore prin scuipare. Pacientul relatează un episod de înnec cu apă pe care l-a avut pe prioada internării în spitalul de unde a fost transferat, în urma căruia i s-a montat sonda nazogastrică. Simptomatologia acuzată de pacient la momentul evaluării ințiale a fost: imposibilitatea înghițirii de lichide, alimente solide și a propriilor secreții; teamă, anxietate și frică de a nu se 
înneca și a se sufoca, gură uscată, spută și secreții groase, cleioase pe care le elimina prin scuipare în permanență; senzație de înnec și nod în gât; frecvente episoade de sughiț; senzație dureroasă la nivelul gâtului ce a apărut ca urmare a procedurilor multiple (5 încercări) de introducere a sondei nazogastrice; pierdere în greutate; deprivare de somn și oboseală acută ca urmare a hipervigilenței din timpul nopții și a eliminării constante a secrețiilor. Având în vedere diagnosticul specific al pacientului, acesta nu prezenta deficite de natură motorie a membrelor superioare sau inferioare, funcțiile de autoîngrijire de fiind deloc afectată în urma accidentului vascular cerebral, abilitățile de comunicare erau funcționale atât din punct de vedere receptiv cât și expresiv.
În baza evaluării obiective clinice s-a constat: C.M este un pacient cooperant și implicat în demersul evaluativ, orientat temporo-spațial, prezintă disfagie pentru solide și lichide ca urmare a unui accident vascular cerebral în teritoriul pseudobulbar de $4 \mathrm{~mm}$. Ca metodă de hrănire utilizează independent o metodă alternativă de nutriție și anume tub nasogastric de aproximativ 4 săptămâni.

Pe parcursul primei întâlniri pacientului i s-a aplicat instrumentul de evaluare clinică a deglutiției, Wather test și Modified wather test ce au avut ca scop examinarea structurilor anatomice implicate în deglutiție, motricitatea și coordonarea acestor structuri, precum și screeningul deglutiției. În tabelul de mai jos sunt prezentate toate datele pe care leam obținut în urma procesului evaluativ inițial.

\section{Tabel II. Rezultate obținute în urma aplicării}

\section{Instrument de evaluare clinică a deglutiției \\ Modified Wather swallow test; respectiv Water swallow test}

Dentiție dentiție completă, cu o igienă bună fară resturi alimentare, carii, sau absența dinților

Buze $\quad$ tipic conformate, în starea de repaus nu se indentifică asimetrii, edeme, eriteme sau leziuni, prezintă o bună mobilitate și motricitate, tonus și forță musculară bună, sunt prezente mișcări de protruzie, retragere și rotație a buzelor, fără a fi prezente mișcări involuntare, spasme, tremus etc

\begin{tabular}{ll}
\hline Limbă & în stare de repaus prezintă o conformație normală, simetrică fără edeme, eriteme sau \\
& leziuni; prezintă un tonus musculat bun în timpul stării de proeminență retragere și \\
& lateralizare, mișcările sunt constante, succesive, controlate, fără mișcări parazite, tremur, \\
& spasme sau diskinezii; realizează mișcări de coborâre/ridicare, lateralizare, rotație fără \\
& modificări clinice;
\end{tabular}

Maxilar maxilar normal configurat, mobil, ce realizează mișcări de deschidere/închidere, lateralizare, proeminență, retragere fără mișcări involuntare sau necontrolate precum tremur, spasm, semiocluzie

\footnotetext{
Palatul normal configurat fără edeme, eriteme, leziuni, ușor coborât spre dreapta ca urmare a moale $\quad$ sondei nazogastrice, simetric, cu o senzație ușor întârziată de gag, mișcarea de ridicare a valului prezentă și susținerea acestuia ușor modificată; fără modificări în mișcările alternative de ridicare/relaxare.
} 


\begin{tabular}{|c|c|}
\hline Respirație & $\begin{array}{l}\text { respirație normală, diferențiază respirația orală de cea nazală, undă respiratorie pe inspir } \\
\text { profundă, lungă, susținută; volum respirator tipic, TMF (timpul maxim de fonație } 15 \text { sec.) }\end{array}$ \\
\hline Voce & $\begin{array}{l}\text { normală, vibrantă, sonoră, gravă, cu volum normal și intensitate vocală optimă, testul s/z } \\
\text { negativ clinic. }\end{array}$ \\
\hline Deglutiție & $\begin{array}{l}\text { C.M. prezintă o disfagie moderată orofaringiană pentru solide și lichide cu o încărcătură } \\
\text { somatică de tipul axiogenă crescută. Prezintă un grad de vigilență și atenție crescut, fără } \\
\text { pneumonii în antecedentele medicale. În urma administrării protocolului de testare } \\
\text { prezintă în cazul consistenței apei tuse spontană și voluntară puternică, cu senzație de } \\
\text { înnec, senzație de rest lichid la nivelul gâtului; curăță voluntar gâtul prin raclaje } \\
\text { consecutive puternice; în cazul modificării consistenței alimentare pacientul prezintă o } \\
\text { ușoară ameliorare pentru consistența nectarului, însă în cazul consistențelor mai groase } \\
\text { precum budincă simptomatologia persistă cu dificultate crescută în înghițire. De } \\
\text { asemenea, se observă o creștere a oboselii pe parcursul administrarii orale, cu modificări } \\
\text { ușoare ale vocii, voce umedă. }\end{array}$ \\
\hline
\end{tabular}

A doua etapă a evaluării a constat în aplicarea testelor ce se bazau pe evaluare subiectivă a pacientului și făceau referire la simptomatologia problemelor de deglutiție, dar și aspecte ce țin de calitatea vieții.

\section{Rezultate obținute în urma evaluării subiective}

\section{Interpretare cantitativă}

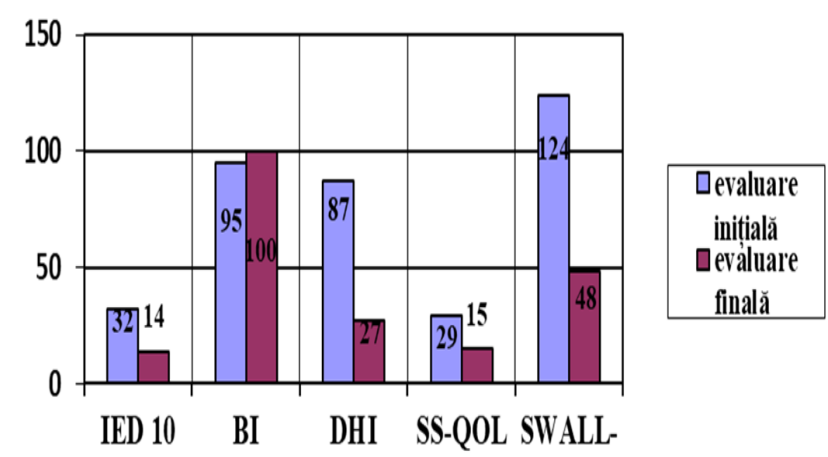

QOL

Figura 1. Grafic comparativ a scorurilor inițiale și finale ale lui C.M

\section{Interpretarea calitativă}

În urma aplicării instrumentului de evaluare a disfagiei (IED-10), C.M. a obținut la evaluarea inițială un scor de 32 , pe când în cadrul evaluării finale scorul său a scăzut la 14, fapt ce indică o evoluție favorabilă în reabilitatea disfagiei. Un astfel de scor indică faptul că C.M se confruntă $\mathrm{cu}$ o disfagie moderată ce îi afectează semnificativ viața, hrănirea realizându-se prin sondă nazogastrică. Itemii ce au indicat răspunsuri maxime au fost "Datorită problemei de deglutiție nu mănânc în locuri publice", "Înghițitul de lichide presupune efort suplimentar", "Înghițitul de solide presupune efort suplimentar", "Înghițitul pastilelor presupune un efort suplimentar.", "Actul înghițirii îmi provoacă stres", pe când itemul "Datorită problemei de deglutiție îmi este afectată pofta de mâncare" are un răspuns minim. Diferența dintre evaluarea inițială și cea finală indică o scădere mai mare de $50 \%$ a simptomatologiei acuzate de către pacient, acesta la externare hrănindu-se numai oral, sonda nazogastrică fiindu-i scoasă după 3 săptămâni de la începerea programului de recuperare. În ceea ce privește scorul obținut de C.M la Indexul Bartel putem afirma faptul că la evaluarea inițială acesta 
a înregistrat un scor de 95, iar la cea finală un scor de 100, ceea ce indică de fapt că nivelul de funcționare a lui C.M este unul foarte bun, iar impactul specific al accidentului vascular cerebral în zona pseudobulbară generează dificultăți stric la nivelul musculaturii faringelui $\mathrm{cu}$ implicare directă în deglutiție. Acest scor indică cu precădere dificultăți doar în domeniul hrănirii, C.M. hrănindu-se singur prin sonda nazogastrică. În cazul Indexului de Handicap pentru Disfagie, C.M a obținut un scor de 87 în cadrul evaluării inițiale, scor ce s-a modificat după parcurgerea planului de tratament la 28. Scorul crescut obținut de către C.M. indică o serioasă dificultate în înghițire. Scăderea semnificativă a acestui scor se explică pe fondul ameliorării înghițirii, C.M înlocuid hrănirea prin mijloace alternative cu o dietă orală ce constă în modificarea consistenței alimentare. În ceea ce privesc scorurile obținute la scalele care surprind componenta de calitate a vieții lui C.M. i s-au aplicat două chestionare SS-QOL și SWALL-QOL. În cazul primului chestionar, SS-QOL, ce evaluează impactul accidentului vascular asupra calității vieții, C.M. a obținut la evaluarea inițială un scor de 33, ceea ce confirmă faptul că impactul accidentului vascular suferit de C.M. nu a fost unul major, ce nu a avut implicații negative asupra intregrității fizice, a mobilității și funcționării motorii și a autonomiei personale, a funcționării degetelor de la mâini, etc. $\mathrm{Cu}$ toate că impactul accidentului vascular cerebral suferit de C.M a fost unul ce a determinat probleme specifice de natură deglutițională, la evaluarea finală s-a observat o scădere a scorului inițial la 17 , ceea ce indică faptul că totuși C.M a prezentat îmbunătățiri la subscalele energie, roluri familiale și asupra dispoziției sale față de condiția sa.

Cel de-al doilea instrument ce a evaluat calitatea vieții la persoanele cu disfagie a fost SWALL-QOL, unde C.M. în faza inițială a testării a înregistrat un scor de 124, ceea ce indică că participantul la studiu prezintă probleme semnificative de înghițire ce îi afectează viața într-un mod marcant. Cele mai importante domenii ce au înregistrat scoruri crescute au fost cele legate de durata alimentației, frecvența simptomelor, frica și conținutul emoțional, somnul și oboseala. La evaluarea finală C.M. a obținut la chestionarul SWALL-QOL un scor de 48 , ceea ce indică succesul demersului terapeutic asupra simptomatologiei și a evoluției pozitive a cazului. Astfel la domeniile la care inițial C.M a obținut scoruri maxime, la evaluarea finală acestea s-au diminuat semnificativ, ceea ce indică o creștere a calității vieții și o apropiere cât mai mare de viața anterioară a acestuia.

Concluzii generale

Rezultatele obținute prin aplicarea Instrumentului de evaluare a deglutiției (IED-10) a relevat faptul că, patru din cei șase participanți prezentau disfagie moderată spre severă, pe când doi dintre aceștia prezentau doar forme ușoare de disfagie, un caz pentru lichide, iar celălalt pentru înghițirea pastilelor. Având în vedere evoluția datele pe care pacienții leau înregistrat la finalul perioadei de cercetare ca urmare a parcurgerii programului de recuperare pentru disfagie, putem afirma faptul că impactul terapiei logopedice a avut un efect pozitiv asupra ameliorării simptomatologiei inghițirii, pacienții reușind să se alimeteze mult mai ușor, mai corect și cu un risc de 
aspirație mai mic. Dintre cei șase participanți la doi dintre aceștia li s-au diminuat în totalitate simptomele, ei alimentându-se și hidratându-se normal, doi prezintă simptomatologie ușoară în curs de remisie, iar pe când ceilalții doi prezintă o dietă pasierată de consistența piureului, alimentelor moi și semitari.

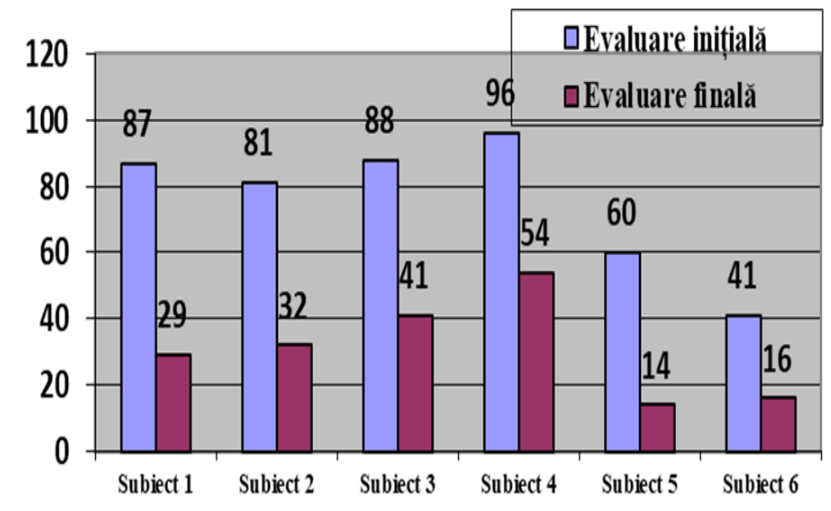

Figura 2. Scorurile obținute de subiecți la Instrumentul de evaluare a disfagiei (IED-10)

Prin analiza scorurilor obținute de pacienți la instrumentele Deglutition Handicap Index și Swalloing Quality of life test s-a putut observa faptul că cu cât scorurile sunt mai mari cu atât impactul asupra calității vieții va fi unul mai semnificativ. $\mathrm{Cu}$ alte cuvinte dacă pacientul prezintă deficite severe ale înghițirii asociate $\mathrm{cu}$ o serie de metode alternative de alimentare precum sunt sonda gastrică, sonda nazogastrică, hrănirea parienterală, cu asociere de traheostomizare cu atât perioada de recuperare va fi mai lungă, iar progresele recuperatorii mai lente cu pondere mai redusă de recuperare. Prin urmare este foarte important în aceste cazuri să ținem seamă de gravitatea efectelor accidentetului vascular survenit asupra pacientului și dacă acestea rămân izolate doar la nivelul deglutiției sau se asociază și cu alte dificultăți motorii. Pacienții a cărui diagnostic a fost exclusiv în zona trunchiului cerebral și nu au prezentat și alte deficite de natură motorie au înregistrat îmbunătățiri semnificative clinic, calitatea vieții findu-le influențată într-un mod pozitiv. În schimb în cazul pacienților care au prezentat accidente vasculare profunde $\mathrm{cu}$ traheosomizare progresul recuperator a fost unul ușor mai săzut, însă care a generat o scădere a scorului la instrumentul de evaluare a calității vieții, indicâd astfel o calitate a vieții crescută.

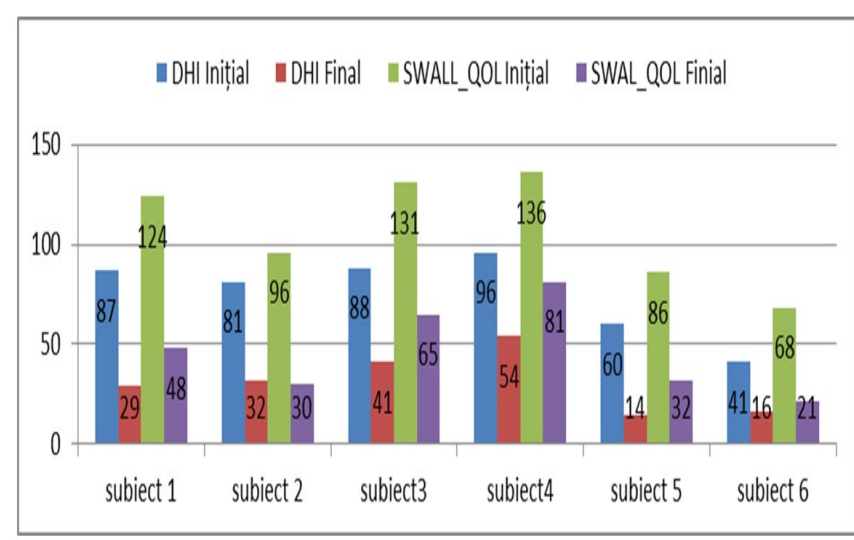

Figura 3. Scorurile obținute de subiecți la DHI și SWALL-QOL

În ceea ce privește corelația dintre scorurile obținute de subiecți la Indexul Barthel (BI) și scorurile obținute de aceștia la chestionarul Stroke Specific Quality of life (SS-QOL) putem afirma faptul că există o corelație invers proporțională dintre acestea. Adică un scor crescut la BI va indica un grad înalt de funcționare și mobilitate a pacientului, ceea ce va determina un scor scăzut la SS-QOL. Dintre cei șase pacienți incluși în cadrul acestui studiu doar un singur subiect prezintă un nivel de mobilitate și independență crescut, impactul accidentului vascular pe care l-a suferit 
fiind în zona pseudobulbară, generându-i doar deficite în hrănire. În schimb în cazul celorlalți cinci subiecți efectele patologiei suferite au indicat un impact negativ crescut asupra mobilității, funcționalității și independenței aceștora, prin urmare scorurile la SS-QOL sunt mult mai crescute ceea ce indică o calitate a vieții mai scăzută. Aceste scoruri se asociază deseori în rândul pacienților $\mathrm{cu}$ instabilitate emoțională, episoade de plâns facil, inhibiție emoțională scăzută, stări depresive ducând deseori la izolare socială, refuz de cooperare terapeutică, pusee de agresivitate și impulsivitate.

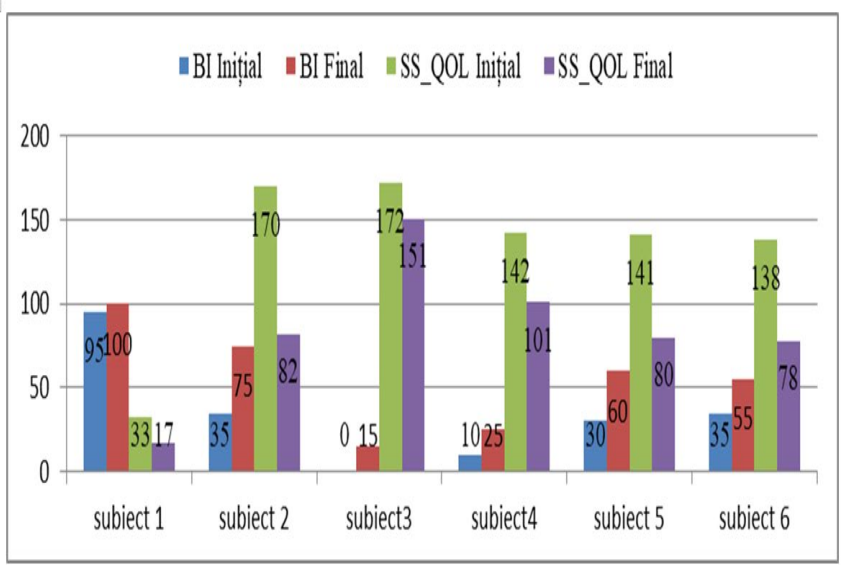

Figura 4. Scorurile obținute de subiecți la BI și SS-QOL

Totuși efectele terapiei disfagiei asupra calității vieții personaleor cu patologie neurologică prezintă un efect pozitiv asupra acestora, diminuând semnificativ riscul de manutriție, dezhidratare și complicații pulmonare grave ca urmare a pneumoniei de aspirație. Această concluzie vin în sprijinul ipotezelor noastre de cercetare, subliniind impactul benefic asupra creșterii independeinței fizice a persoanei de a se hrăni și hidrata, de a se reintegra social și de a participa la viața cotidiană a familiei.
De asemenea este necesar să prezentăm și limitele acestei cercetări. Una dintre aceste limite ar fi faptul că pentru a putea observa $\mathrm{cu}$ o mai mare certitudine impactul terapiei logopedice asupra calității vieții la persoanele cu patologii neurologice, este necesar un eșantion semnificativ pentru populația româniei, și un număr mai mare din punct de vedere numeric. De asemenea este imperios necesar utilizare formelor de evaluare clinică obiectiv. O altă limită pe care am identificat-o a fost topografia variată a patologiei pacienților ce au prezentat disfagie și diferența dintre duratele de suferință la care s-a intervenit. În cazul unor pacienți intervenindu-se terapeutic după o lună de la accidentul vascular cerebral, la alții după patru sau opt luni de la patologia survenită.

\section{Bibliografie}

Ayres, A., Jotz, G.P., Mello Rieder, C.R., Schumacher Schuh, A.F.și Olchik, M.R. (2016). The Impact of Dysphagia Therapy on Quality of Life in Patients with Parkinson's Disease as Measured by the Swallowing Quality of Life Questionnaire (SWALQOL) Int Arch Otorhinolaryngol, 20(3): 202-206

Bhattacharyya, N. (2014). The Prevalence of Dysphagia Among Adults in the United States, Otolaryngol Head Neck Surgicail, 151(5):765-769

Cabré, M., Serra-Prat, M., Force,L., Almirall, J., Palomera, E., Clavé, L. (2014). Oropharyngeal Dysphagia Is a Risk Factor for Readmission for Pneumonia in the Very Elderly Persons: Observational Prospective Study. Journal Gerontology A 
Biological Science Medical Science, 69(3):330-7

Carnaby-Mann, G., Lenius, K., Crary, M. (2007). Update on Assessment and Management of Dysphagia Post Stroke. Northeast Florida Medicine, 58(2):31-34

Jones B, (2003). Normal and Abnormal Swallowing. Imaging in Diagnosis and Therapy New York, ed. SpringerVerlag

Livia, S., Madhavan, A., Carnaby, G., Crary, M.A. (2012). Dysphagia in the Elderly: Management and Nutritional Considerations. Clinical In Intervention Anging, 7:287-298

McKevitt, C., Redfern, J., La-Placa,V., Wolfe, C.D.A. (2003). Defining and Using Quality of Life: A Survey of Health Care Professionals. Clinical rehabilitation, $17(8): 865-70$

Norine, C., Martin, R.E., Salter, K.L., Teasell, R., T.(2009). A Review of the Relationship Between Dysphagia and Malnutrition Following Stroke Journal of rehabilitation Medicine 41(9):707713

Ronkainen, J., Talley, N.J., Aro, P.T, Storskrubb, T., Johansson, S.T., Lind, T., Bolling-Sternevald, E., Vieth, E., Stolte, M., Walker, M., Agréus, L. (2007). Prevalence of Oesophageal Eosinophils and Eosinophilic Oesophagitis in Adults: The Population-Based Kalixanda Study. Gut, 56(5):615-620

https://apps.who.int/iris/bitstream/handl e/10665/42407/9241545429 rum.pdf;js essionid $=383 \mathrm{EFEoF} 292 \mathrm{Do}_{4} \mathrm{~B} 84541 \mathrm{EAD}$ $5 \mathrm{~A}_{5} 6 \mathrm{DC}_{2} \mathrm{C}_{3}$ ? sequence $=5$

https://iddsi.org/Testing-Methods https://www.worldgastroenterology.org/ UserFiles/file/guidelines/dysphagiaenglish-2014.pdf

1. Profesor: Școala Gimnazială Specială-CRDEII, ClujNapoca.

Email: popa.ralucamariana@yahoo.com 


\title{
Abordarea interdisciplinară a despicăturilor facio-labio-palatine
}

\author{
Ioana Mădălina ORIAN ${ }^{1}$
}

\begin{abstract}
Labio-maxillo-palatine clefts represent the most common congenital anomaly of all congenital malformations of the face and they are the most frequent cause of rhinolic disorders. The complexity of the therapeutic approach is determined by nutrition and eating problems, hearing and ENT problems, dento-facial and orthodontic abnormalities, breathing disorders, phonation disorders, reduced speech intelligibility, various physiognomic disorders.

The presented case study emphasizes the need of an interdisciplinary approach to labio-maxillo-palatine clefts and follows the recovery process from a multidisciplinary perspective. The conclusions of the paper support the idea that the recovery process of the child with facio-labio-palatine cleft is a complex, long-termed one and the concern of the speech and language therapist to expand his field of activity is justified because this disorder involves pre and post surgery intervention and the therapist supports the entire process in all the mentioned areas.
\end{abstract}

Keywords: labio-maxillo-palatine cleft, open rhinolalia, orthodontic devices, speech intelligibility, speech disorder

\section{Introducere}

În ultimii ani se poate observa o preocupare în vederea extinderii domeniului de activitate a terapeutului limbajului, existând o legătură tot mai strânsă între intervenția în reabilitarea limbajului, domeniul ORL și intervenția în cazul tulburărilor de alimentație (băut, mâncat, înghițit).

În 2015, ASHA (American Speech Language Hearing Association) delimitează domeniul practicii logopedice, în ceea ce privește tulburările de limbaj și vorbire întâlnite la copii, astfel (Bodea Hațegan, 2016):

Tulburări de vorbire: apraxia, bâlbâiala, dizartria, tulburările de voce, tulburările miofuncționale de la nivel orofacial, tulburările sunetelor vorbirii (tulburările de pronunție și fonologice);

Tulburări de limbaj: dificultăți specifice de învățare, tulburări de limbaj apărute la vârsta preșcolarității, mutism electiv;
Patologii medicale care implică tulburări de limbaj și vorbire: ADHD, tulburarea din spectrul autist, despicăturile facio-labiopalatine, traumatismele craniene, afectarea emisferei cerebrale drepte.

\section{Direcții de cercetare}

\section{Despicăturile facio-labio-palatine}

Despicăturile labio-maxilo-palatine reprezintă cea mai frecventă anomalie congenitală dintre toate malformațiile congenitale ale feței, care pot să apară în cadrul unor sindroame genetice sau pot fi izolate, adică neasociate unei alte boli (Tote et al, 2014) și reprezintă cauza cea mai frecventă pentru tulburările rinolalice (Bodea Hațegan, 2016).

Despicăturile constituie o provocare și o serioasă problemă medicală prin prisma varietăților de forme clinice pe care le îmbracă, a tulburărilor funcționale asociate, a tratamentului complex și special pe care îl necesită și a managementului terapeutic extrem de 
complex și divers (Burlibașa, 1999), care se desfășoară pe o perioadă îndelungată de timp și care include în mod obligatoriu o echipă multidisciplinară.

\section{Greșterea și dezvoltarea cranio-facială}

Despicăturile labio-maxilo-palatine reprezintă tulburări ale aparatului dentomaxilar care apar ca fiind anormale în cadrul procesului de dezvoltare craniofacială, proces care are loc în primele săptămâni de viață intrauterină.

Principalele etape ale dezvoltării craniofaciale cuprind:

Formarea mugurilor faciali, la sfârșitul celei de-a patra săptămâni de viață intrauterină. Această etapă este ulterior completată de formarea mugurilor nazali;

Formarea buzei superioare și a palatului primar. Dacă în această etapă nu se produce alipirea celor doi muguri maxilari sau este incompletă, poate să apară despicătura labială;

Formarea palatului secundar, care formează planșeul foselor nazale și plafonul cavității orale. În partea anterioară, acesta cuprinde palatul dur iar palatul moale se află în poziție posterioară iar acesta reprezintă o componentă esențială pentru o respirație normală, masticație, deglutiție și vorbire (Wyszynski, D.F., 2002).

Dacă oricare dintre etape nu se desfășoară, total sau parțial, așa cum este firesc, apar diversele forme ale despicăturilor labiomaxilo-palatine. Mult timp s-a încercat să se descopere care sunt cauzele care stau la baza producerii despicăturilor, s-au elaborat multe și variate teorii, însă nici una nu a prezentat o explicație a cauzelor și a mecanismelor care produc aceste anomalii congenitale. Se pare că, ele sunt cauzate de interacțiunea mai multor factori, non-genetici sau/și genetici.

Formele pe care le poate lua despicătura sunt diverse și particulare fiecărui caz dar oricare dintre următoarele componente poate fi afectată: buze, prag narinar, creastă alveolară, palatul dur, vălul palatin, lueta, fiind prezentă în multe dintre cazuri comunicare între fosele nazale și cavitatea orală.

Copiii cu despicătură prezintă adesea diverse anomalii dentare, care par a nu exista la fel de frecvent în cazul copiilor care nu suferă de această afecțiune. Printre anomaliile cele mai frecvente se numără: modificări de număr (incluzii, hipodonții, dinți supranumerari) și modificări de formă. Dimensiunea dinților e mai mică la copiii cu despicătură iar cei mai mici dinți sunt reprezentați de cei cu despicătură palatină. Prezența unui dinte supranumerar pe partea afectată e a doua cea mai întâlnită anomalie dentară (Tote et al, 2014).

O particularitate observată la copiii cu despicături, care influențează mult demersul logopedic, o reprezintă retrognația maxilară. Un timp, această caracteristică de creștere și dezvoltare s-a pus pe seama țesutului cicatricial rezultat în urma intervenției chirurgicale, retrognația maxilară apărând ca secundară operației de reconstrucție. Dar, numeroase studii efectuate în ultimul timp, care s-au efectuat atât pe pacienți operați cât și pe cei neoperați, arată că pacienții cu despicătură prezintă mecanisme intrinseci de dezvoltare care determină o rată mai mică de creștere a maxilarului. Astfel, copiii cu despicătură prezintă etajul inferior al feței mai mic, 
înălțimea și lungimea maxilarului superior cu dimensiuni mai mici față de media normală. (Bjork, 2007; Saperstein, 2012).

S-a insistat în prezentarea detaliată a tipurilor și formelor pe care această afecțiune o poate da pentru a scoate în evidență particularitățile pe care le prezintă asupra fiecărui caz și pentru a sublinia faptul că fiecare intervenție chirurgicală presupune o nouă adaptare la noile posibilități articulatorii pe care intervenția o oferă și efectele psihologice ale intervenției asupra structurării personalității care determină deschiderea și motivarea copilului spre terapia logopedică.

\section{Intervenții terapeutice la copiif cu despicături}

Complexitatea și diversele forme pe care le poate lua această afecțiune necesită o abordare interdisciplinară, managementul terapeutic este unul complex, de lungă durată și necesită o echipă multidisciplinară din care fac parte: medic pediatru, chirurg maxilo-facial, specialist ortodont, logoped, psiholog, medic specialist psihiatrie pediatrică, ORL-ist, anestezist.

În acest moment, nu există o schemă fixă de tratament pentru tratarea despicăturilor, existând două protocoale terapeutice diferite: protocolul chirurgical Milan și protocolul chirurgical Oslo (Meazzini, 2008). Fiecare caz este unic, de aceea întreaga intervenție este puternic individualizată și necesită control și supraveghere adecvată pe toată durata tratamentului.

Diagnosticarea despicăturii labiale se poate realiza ecografic după primele 16 săptămâni de sarcină. Despicătura palatină este mai greu de observat prin această metodă (Shaikh et al, 2001). Discuția cu chirurgul și planificarea intervenției se poate realiza prenatal, după realizarea diagnosticării prin ecografie. Începând cu primul moment de viață al copilului, se vor utiliza tetine speciale pentru hrănirea sugarului (Miloro et al, 2004). Hrănirea sugarului și monitorizarea permanentă a greutății este importantă pentru intervențiile chirurgicale ulterioare. O greutate și o dezvoltare corespunzătoare ajută copilul să facă față operațiilor chirurgicale (Hurubeanu, 2002).

\section{Tratamentul ortodontic în cazul despicăturilor labio-maxilo-palatine}

În cazul despicăturilor labio-maxilopalatine se recomandă tratament ortodontic precoce, încă din primele săptămâni de viață. Tratamentul ortodontic este extrem de important și însoțește toate procedurile managementului terapeutic al despicăturilor labio-maxilo-palatine. Tratamentul ortodontic a fost împărțit în 4 etape: tratarea ortodontică a nounăscutului, dentiția temporară, dentiția mixtă, dentiția permanentă. Obiectivul tratamentului ortodontic este repoziționarea corespunzătoare a fragmentelor de maxilar separate și dislocate datorită funcțiilor patologice (discontinuitatea musculaturii labiale și interpunerea limbii în fisură)(Mercado A., Vig, K., 2019).

Tratamentul ortodontic pre-chirurgical se aplică înaintea corecției primare a despicăturii labiale (Salyer K. E., 2001) și ajută la remodelarea narinei, pentru apropierea segmentelor buzei sau a arcadei dentare. 
În tratamentul ortodontic pre-chirurgical se folosesc diverse plăci care au rol în:

-Ameliorarea condițiilor pentru corectarea chirurgicală ulterioară;

- Împiedică pătrunderea limbii în fisură;

-Favorizează apropierea fragmentelor maxilare;

-Se ușurează alimentația sugarului.

Repararea primară a despicăturii labiale are loc după primele 12 săptămâni de viață (Kirschner R. E., LaRossa D., 2000). Repararea primară a despicăturii palatine, cu veloplastie se realizează după primele 6-12 luni (Arosarena O. A., 2007). Se realizează tratament ortodontic pentru expansiunea maxilarului pentru dentiția temporară și tratament ortodontic pentru expansiunea maxilarului și avansarea acestuia pentru dentiția mixtă (Shetye P. R., 2012).

Rinoplastia se realizează după vârsta de 5 ani (Katzel E. B. et al, 2009) iar grefa osoară înaintea erupției dinților permanenți (Miloro M. et al, 2004, LevyBercowski D. et al., 2011). Tratamentul ortodontic pentru alinierea arcadelor se face pe dentiția permanentă (Boyne P. J., Sands N. R., 1972).

Chirurgia ortognată se referă la operațiile la nivelul maxilalelor practicată de un medic chirurg maxilo-facial. Operația este efectuată în cazul defectelor scheletale cu o ocluzie dentară incorectă, care nu poate fi rezolvată doar prin tratament ortodontic de îndreptare a dinților. Oasele maxilare pot fi dezvolte în exces sau deficitar. Scopul este deci de a rezolva mușcătura și de a reda pacienților un aspect facial plăcut și armonios dar și de a îmbunătăți respirația în timpul somnului prin lărgirea
pasajului
aerian
(dentalconceptstudio.ro)
superior.

Chirurgia ortognată pentru avansarea maxilarului se realizează după erupția dinților permanenți, alinierea arcadelor și terminarea creșterii (Shetye P. R., 2012) iar tratamentul ortodontic post-chirurgical pentru închiderea spațiilor reziduale și ultimele ajustări ale ocluziei (KuijpersJagtman A. M., 2006) precum și eventualele reconstituiri protetice (Vlachos C. C., 1996) se execută după intervenția de chirurgie ortognată.

În toată perioada de recuperare a copilului cu despicătură labio-maxilo-palatină, în tratamentul ortodontic, la aprecierea specialistului ortodont, se utilizează plăci palatinale, plăci linguale, gutiere, plăci de dilatare transversală utilizate în maxilarul îngust, aparate fixe și/sau mobile și aparate extraorale. Aparatele extraorale se utilizează în tratamentul precoce al prognatismului mandibular, în dentația temporară sau mixtă incipientă. Rolul lor este de inhibare a creșterii anterioare a mandibulei.

\section{Aspecte ale demersului terapiei logopedice}

Despicăturile labio-maxilo-palatine pot determina dezechilibrul mușchilor orofaciali, determinat de cauzele organice și funcționale specifice, precum și respirație orală cu postura anormală a limbii cauzată de problemele de natură ORL (de exemplu otita medie seroasă întâlnită frecvent în cazul acestei afecțiuni) sau malocluzie determinată de alterarea structurii dentale și scheletice. Acest dezechilibru muscular orofacial are ca și consecință defecte de pronunție a diferitelor sunete $(b, p, m ; d, t, n ; l, r ; s, z$, s, ț). 
Deglutiția este actul motor prin care bolul alimentar ce s-a format în cavitatea bucală străbate faringele și esofagul pentru a ajunge în stomac (Mureșan, R. 2015). În funcție de zona traversată de bolul alimentar există trei timpi ai deglutiției: bucal, faringian și esofagian. În cazul despicăturilor labio-maxilo-palatine, timpul bucal al deglutiției poate fi puternic afectat deoarece organele cuprinse în acest proces sunt afectate: buze, dinți, mandibulă, limbă. Timpul bucal afectat poate determina alterarea celorlalți timpi bucali, deglutiția fiind astfel deficitară și realizându-se îngreunat.

Diferențierea respirației orale de cea nazală și a respirației verbale de cea nonverbală reprezintă un prim obiectiv în terapie.

Indiferent de forma rinolaliei determinate de despicătură, reușita intervenției logopedice se bazează pe (Bodea Hațegan, 2016) :

- Dezvoltarea preachizițiilor;

- Dezvoltarea abilităților respiratorii;

- Dezvoltarea abilităților de diferențiere auditiv-verbală;

-Dezvoltarea abilităților motorii generale și fine.

Copiii născuţi cu despicătură unilaterală totală se confruntă cu probleme complexe de sănătate și cu o serie de tulburări funcționale. Dintre acestea se pot aminti:

Probleme de nutriţie și alimentație: părinţii se confruntă cu dificultăţi de hrănire a copilului, unii dintre copii au dificultăţi ale alimentaţiei la sân, având nevoie de tetină specială; reflux nazal al lichidelor şi alimentelor moi, uneori şi ale solidelor (regurgitare nazală);
Probleme auditive şi ORL: dificultăţi ale respiraţiei; complicaţii la nivelul urechii medii, apariția de otite seroase, acumulare de lichid în urechhea medie care poate duce la degradarea treptată a auzului cu afectarea auzului fonematic; infecţii respiratorii superioare frecvente (răceli, sinuzite);

Anomalii dentofaciale şi ortodontice: reconstrucția aparatului fonoarticulator; buza superioară rigidă; nevoia unui aparat de modelare a narinei încă de la primele săptămâni de viaţă; nevoia aparatelor dentare pentru corecția poziţiei vicioase a incisivilor de pe maxilarul superior dar şi a maxilarului;

Tulburări de respirație (nu diferențiază respirația orală de cea nazală, volumul respirator este afectat, respirația este preponderent superficială, toracală) (Bodea Hațegan, 2016);

Tulburări de fonație (vocea puternic nazalizată);

Reducerea inteligibilității verbale din cauza faptului că sunt afectate majoritatea sunetelor, mai puțin sunetele nazale (Bodea Hațegan, 2016);

Diverse tulburări fizionomice.

Terapia logopedică în cazul copiilor cu despicătură labio-maxilo-palatală se realizează în două etape: etapa preoperatorie și etapa postoperatorie. Reabilitarea preoperatorie câștigă din ce în ce mai mult teren în medicină și se referă la pregătirea pacienților pentru tratamente programate și intervenții, având ca scop acela de a reduce riscurile și complicațiile, ajutând la refacerea mai rapidă a acestora (intramed.ro). Etapa logopedică preoperatorie este esențială și 
se stabilește nivelul preachizițiilor și presupune parcurgerea terapiei logopedice clasice, fără a insista asupra emiterii, consolidării și automatizării sunetele. (Guțu, 1974; Moldovan, 2006)

\section{Pozitia ASHA referitoare la despicăturile labio-maxilo-palatine}

ICF (International Classification of Functioning, Disability and Health) este o clasificare a sănătății și a condițiilor legate de sănătate pentru copii și adulți care a fost elaborată de către Organizația Mondială a Sănătății (OMS) și publicată în 2001. Cadrul clasificării poate fi utilizat în practica de colaborare interprofesională și în îngrijirea centrată pe persoană. Acest cadru propune abordarea dizabilității unei persoane în contextul funcționării acesteia la activitățile individuale și a participării la viața de zi cu zi.

Ce sunt obiectivele funcționale bazate pe persoană? Sunt obiective identificate de către client, împreună cu terapeutul, clinicianul și familia, care permit participarea persoanei la activități pline de semnificație și având roluri importante. Aceste obiective se folosesc pentru a valoriza la maxim rezultatele care duc la îmbunătățiri semnificative în ceea ce privește funcționalitatea individului; de a optimiza potențialul persoanei $\mathrm{cu}$ dizabilități având în vedere participarea la activități semnificative; pentru a facilita un parteneriat care să asigure individului și familiei dreptul la opinie în îngrijirea primită și rezultatele obținute; să demonstreze plătitorilor valoarea serviciilor oferite.

În ceea ce privește despicăturile faciolabio-palatine obiectivele se stabilesc din perspectiva următoarelor aspecte:
-Starea de sănătate: tulburarea sau boala care oferă comorbiditățile și prognosticul;

-Funcțiile și structurile corpului: părțile anatomice și funcțiile lor fiziologice;

-Activități și participare: executarea sarcinilor sau implicarea în situații de viață;

-Factori de mediu și personali: factori fizici, sociali, atitudinali și de mediu și factori din viața individului.

Toți acești factori sunt interconectați și se influențează reciproc așa cum sunt prezentați în figura 1:

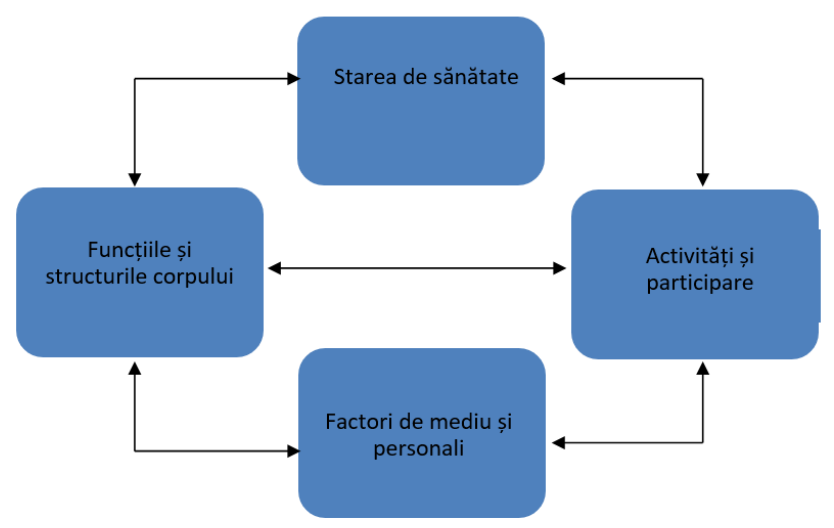

Fig.1: Reprezentarea schematică a interconectivității factorilor care contribuie la stabilirea obiectivelor în demersul terapeutic al despicăturilor facio-labio-palatine

ASHA propune cazul Mariei, pentru a ilustra abordarea despicăturii buzei și a palatului, din perspectiva ICF.

Starea de sănătate: Despicătură unilaterală a buzei și palatului operată, cu închidere adecvată a vălului palatin.

Datele de evaluare

-Funcțiile și structurile corpului

-Despicătură unilaterală a buzei și palatului

-Operată la 3 respectiv 12 luni 
- Închidere adecvată a vălului palatin

Vorbire: Limbajul receptiv și expresiv: mediu și peste mediu dezvoltat

Auzul (stare monitorizată în mod regulat)în limite normale, în ciuda istoricului de otită medie

Articulare și fonologie - erori de articulare compensatorii (sunete glotice pentru $\mathrm{p}, \mathrm{b}$, $\mathrm{t}, \mathrm{d}$; nazalizarea pentru s, z)

Activități și participare

Dificultăți de înțelegere de către ascultătorii mai puțin familiarizați

Participare redusă la activitățile desfășurate la clasă (de exemplu activitățile de grup sau de povestit)

Reticență de a se alătura jocului cu colegii de clasă și de a comunica verbal cu ascultătorii necunoscuți

\section{Factori de mediu și personali}

Maria are 4 ani. Este la grădiniță și are acces la ședințe de terapia limbajului

Are motivația pentru a-și îmbunătăți limbajul astfel încât ceilalți să o înțeleagă

Maria are o dorință puternică de a interacționa social cu colegii ei

Colegii o acceptă și încearcă să o includă pe Maria în jocuri

Are susținerea familiei, prietenilor și a profesorilor

\section{Raționamentul clinic}

Ce deficiențe afectează cel mai mult funcționarea în contextul actual, pe baza evaluării clinicianului și a raportului individual / al familiei?

Care activități sunt cele mai importante pentru individ în contextul actual?
Ce caracteristici personale / de mediu ajută sau împiedică participarea la activități sau situații în situația actuală?

Stabilirea obiectivelor (Obiectivele funcționale ale Mariei):

Obiective pe termen lung

Maria va participa la activitățile desfășurate împreună cu colegii ei și va fi înțeleasă atunci când vorbește cu prietenii și profesorii de la grădiniță și cu ascultătoti nefamiliarizați în contextele cotidiene de viață.

\section{Obiective pe termen scurt}

Maria va emite sunetele $p, b, t, d$ în toate pozițiile regăsite în cadrul cuvintelor, eliminând sunetele glotice în 90\% din situații în propoziții structurate în timpul terapiei individuale.

Maria va emite sunetele $s, z$ în toate pozițiile regăsite în cadrul cuvintelor, eliminând nazalizarea în 90\% din situații în propoziții structurate în timpul terapiei individuale.

Când va fi invitată de către colegii ei la activitățile de joc liber desfășurate în clasă, Maria va participa la conversații în cel puțin 4 din 5 oportunități pe săptămână, așa cum a menționat logopedul și profesorii.

\section{Studiu de caz}

D. s-a născut în luna martie, anul 2012, vârsta actuală fiind de 8 ani și 10 luni, având diagnosticul de cheilopalatoschizis (despicătură unilaterală totală stânga) constatat la naștere. Studiul de caz prezentat urmărește evoluția procesului de recuperare a lui D., de la naștere și până în prezent. 
Copilul este provenit din sarcină cu evoluţie normală, născut la termen, greutatea la naştere 3300 gr, Apgar=8, naștere prin cezariană. La naștere a fost diagnosticată cu cheilopalatoschizis, având 4 intervenţii chirurgicale până în prezent. Prima intervenție a fost de reparare a despicăturii labiale la vârsta de 8 luni, a doua intervenție a fost de reparare a despicăturii palatine care s-a realizat în jurul vârstei de 18 luni, a treia etapă chirurgicală, care a constat în reconstrucția structurii alveolare, s-a realizat în jurul vârstei de 30 de luni iar a patra intervenție s-a realizat după împlinirea vârstei de 5 ani și a constat în îndepărtarea unui dinte supranumerar apărut în zona despicăturii.

Încă de la vârsta de 5 săptămâni până la prima intervenție, fetița a purtat aparat ortodontic care a ajutat la alimentarea cu mai multă ușurință, modelarea narinei stângi și apropierea structurilor buzei și arcadei alveolare, evitând tensiunile care pot apărea în urma intervenției chirurgicale. De la 6 ani, D. poartă o placă de dilatare transversală fixată pe molarii maxilarului superior, utilizată în maxilarul îngust. De la 8 ani și 6 luni, D. poartă aparat dentar fix pe dinții maxilarului superior și „țepi ortodontici” („tongue tamers” sau „habit tamers”) pe doi dintre dinții din față, situați pe maxilarul inferior. Aceste instrumente ortodontice arată ca doi „minițepi” care ajută la antrenarea inconștientă a limbii și reamintește permanent limbii de a folosi palatul în momentul deglutiției, în loc să împingă dinții de jos, cauzând malocluzie (mashpeeortho.com). Aceste instrumente ortodontice care antrenează limba ajută și la antrenarea limbii în vederea emiterii corecte a consoanelor apico-dentale: $t, d$, $\mathrm{n}, \mathrm{s}, \mathrm{z}, \mathrm{t}, \mathrm{r}, \mathrm{l}$.

D. a început intervenția logopedică în jurul vârstei de 2 ani și 10 luni. La începutul terapiei, D. avea doar câteva cuvinte pe care le folosea și nu dorea să își folosească gura ca să vorbească, nu deschidea gura la cerere, când vorbea o făcea doar în șoaptă și nu dorea să repete dacă i se cerea. Având zona bucală afectată în urma intervențiilor chirurgicale, resimțindu-le ca o traumă a zonei, D. nu dădea voie nimănui să îi atingă zona feței. Din punct de vedere a limbajului receptiv, fetița avea o dezvoltare tipică.

D. a fost evaluată logopedic, cu scopul de a determina modalităţile cu care operează în comunicare, nivelul de dezvoltare a limbajului, capacitatea de imitare motrică (imitarea mişcărilor organelor de vorbire) şi verbală (imitarea sunetelor modelate de evaluator), răspunsul la întrebările evaluatorului, depistarea defectelor de pronunţie, în vederea propunerii unui plan de intervenţie logopedică.

La vârsta de 4 ani, copilul a fost diagnosticat cu deficit de cetoliză (deficit enzimatic congenital, boală metabolică) iar, din cauza despicăturii unilaterale totale, tot de la 4 ani prezintă episoade repetate de surditate de transmisie (factori de risc: palatoschizis).

Copilul a fost dus în colectivitate încă de la vârsta de un an, frecventând încă de atunci creșa, apoi grădinița cu program prelungit și ulterior școala. $\mathrm{Nu}$ a avut probleme de adaptare, fetiţa a avut şi are prieteni atât în colectivitate cât şi acasa. Îi place să coloreze, să răsfoiască paginile cărţilor colorate pentru copii şi practică tenis de 
câmp cu multă plăcere şi cu rezultate foarte bune.

Trăind într-un oraș mai mic, până la vârsta de 5 ani, D. a avut parte de mai mulți logopezi, aceștia părăsind orașul pentru a pune bazele unei cariere într-un oraș mai mare. Astfel, la 5 ani și o lună, D. a fost evaluată de un medic specialist psihiatrie pediatrică și un psihopedagog logoped. Fetița avea o dezvoltare fizică, afectivă și cognitivă corespunzătoare vârstei, producție grafică adecvată, personalitate în curs de structurare, dificultăți de pronunție a sunetelor cu substituirea acestora în interiorul cuvintelor, rinolalie; erori de articulare în vorbire cu omisiuni, distorsiuni și substituiri de sunete, inconsistențe în exprimarea sunetelor. În cadrul evaluării s-a aplicat interviul la care au răspuns părinții fetiței și aplicația Pași Prin Lumea Sunetelor (PPLS) pentru analiza pronunției. S-a examinat, de asemenea, aparatul fonoarticulator, capacitatea de a imita mișcările organelor de vorbire (motricitatea aparatului fonoarticulator), limbajul spontan manifestat în decursul evaluării, auzul fonematic, capacitatea de diferențiere fonematică.

\section{Rezultatele evaluării}

Aparatul fonoarticulator: după reconstrucţia aparatului fonoarticulator D. mai prezintă unele particularități care influenţează pronunţia în momentul de faţă: buza superioară rigidă, cu cicatrici, poziția vicioasă a incisivilor de pe maxilarul superior. Coordonare şi capacitate de imitare motrică şi verbală în curs de perfecţionare şi formare.
Pronunţia: vorbire dislalică, neinteligibilă, fetiţa fiind înţeleasă doar de cei din anturaj, foneme pronunţate deficitar, fie sunt distorsionate sau înlocuite. Auz fonematic, capacitate de diferențiere fonematică în curs de perfecţionare, pronunţia este uşor îmbunătăţită în vorbirea reflectată/după model. Alte aspecte surprinse în timpul evaluării: adăugiri sau simplificări ale cuvintelor în discordanţă cu vârsta cronologică.

Vocabularul: este corespunzător vârstei cronologice, D. cunoaşte o serie de noţiuni pe care le utilizează în vorbirea spontană, formulând enunţuri din mai multe cuvinte (3-4 cuvinte).

În momentul evaluării, D. nu diferenţiază tipurile de respiraţie orală de cea nazală, reuşește să sufle în instrumente muzicale şi baloane de săpun dar întâmpină greutăţi, adeseori fetiţa expira pe nas şi nu pe gură în totalitate. Diagnosticul logopedic este de dislalie polimorfă datorată tulburării organice la nivelul aparatului fonoarticulator (despicătură velo-palatină operată), hipoacuzie temporară (otită seroasă în curs de tratare). Se recomandă intervenţia logopedică în vederea mobilizării şi îmbunătăţirii motricităţii aparatului fonoarticulator, remedierea dislaliei şi dezvoltarea limbajului în conformitate cu nivelul de vârstă.

\section{Rezultate obtinute}

Tabel 1: Înregistrarea progresului prin rapoarte ale testelor de evaluare $\mathrm{cu}$ ajutorul aplicației Pași Prin Lumea Sunetelor 
Raport test PPLS, D., 5ani și 1 lună

Răspunsuri corecte: $37 / 79=46,84 \%$

Sunete omise: $11 / 79=13,92 \%$

Sunete distorsionate: $3 / 79=3,8 \%$

Sunete înlocuite: $28 / 79=35,44 \%$

Consoane:

După modul de producere:

Oclusive (p,b,t,d,c,g): 10/18=55,56\%

Fricative (s,z,s,,j,f,v,h): 1/21=4,76\%

Africate (ţ, č, $\breve{\mathrm{g}}): 1 / 9=11,11 \%$

Nazale (m,n): $4 / 6=66,67 \%$

Sonante $(r, 1, m, n): 7 / 12=58,33 \%$

După locul de articulare:

Bilabiale (p,b,m): 6/9=66,67\%

Labiodentale (f,v): $\mathrm{o} / 6=0 \%$

Apico-dentale (t,d,n,s,z,ţ,r,l): 5/24=20,83\%

Alveolare (ş,j): $\mathrm{o} / 6=0 \%$

Palatale (č, $\breve{g}): 1 / 6=16,67 \%$

Velare (c,g): $6 / 6=100 \%$

Laringale $(\mathrm{h}): 1 / 3=33,33 \%$

Vocale

După zona de articulare

Anterioare (e,i): $5 / 6=83,33 \%$

Mediane (a,ă,î): $7 / 7=100 \%$

Posterioare (o,u): $6 / 6=100 \%$

După gradul de deschidere a cavităţii bucale

Deschise (a): $3 / 3=100 \%$

Semideschise (e,ă,o): 8/8=100\%

Închise $(\mathrm{i}, \hat{1}, \mathrm{u}): 7 / 8=87,5 \%$

După rotunjirea buzelor

Rotunjite (labiale) (o,u): 6/6=100\%

Nerotunjite (nelabiale) (e,i,a,ă,î): 12/13=92,31\%
Raport test PPLS, D., 8ani şi 10 luni

Răspunsuri corecte: $66 / 79=83,54 \%$

Sunete omise: o / $79=0,00 \%$

Sunete distorsionate: $12 / 79=15,19 \%$

Sunete înlocuite: $1 / 79=1,27 \%$

Consoane:

După modul de producere:

Oclusive (p,b, t, d,c,g): $16 / 18=88,89 \%$

Fricative $(\mathrm{s}, \mathrm{z}, \mathrm{ş}, \mathrm{j}, \mathrm{f}, \mathrm{v}, \mathrm{h}): 21 / 21=100,00 \%$

Africate $(t, \breve{c}, \breve{g}): 1 / 9=11,11 \%$

Nazale (m,n): 6 / $6=100,00 \%$

Sonante $(\mathrm{r}, \mathrm{l}, \mathrm{m}, \mathrm{n}): \mathrm{g} / \mathrm{12}=75, \mathrm{oo} \%$

După locul de articulare:

Bilabiale (p,b,m): $9 / 9=100,00 \%$

Labiodentale (f, v): $6 / 6=100,00 \%$

Apico-dentale (t, d, n, s,z, ț, r, l): $16 / 24=66,67 \%$

Alveolare (ş, j): 6 / $6=100,00 \%$

Palatale (č, ğ): $1 / 6=16,67 \%$

Velare (c, g): $6 / 6=100,00 \%$

Laringale $(\mathrm{h}): 3 / 3=100,00 \%$

Vocale

După zona de articulare

Anterioare (e, i): $6 / 6=100,00 \%$

Mediane (a, ă, î): $7 / 7=100,00 \%$

Posterioare (o, u): 6 / $6=100,00 \%$

După gradul de deschidere a cavității bucale

Deschise (a): $3 / 3=100,00 \%$

Semideschise (e, ă, o): $8 / 8=100,00 \%$

Închise (i, î, u): 8 / $8=100,00 \%$

După rotunjirea buzelor

Rotunjite (labiale) (o, u): $6 / 6=100,00 \%$

Nerotunjite (nelabiale) (e, i, a, ă, î): $13 / 13=100,00 \%$
În ceea ce privește evaluarea inteligibilității vorbirii, folosind scala Speech Intelligibility Rating Scale-SIR (Bodea Hațegan, 2016), D. a pornit de la 1, ceea ce presupune că vorbirea acelei persoane este total neinteligibilă pentru ascultător iar în prezent este la 4, ceea ce înseamnă că vorbirea persoanei este inteligibilă în cea mai mare parte, chiar și pentru un vorbitor mai puțin familiarizat cu specificul articulator și fonator al unei persoane rinolalice, cu puține și mici excepții.

\section{Sedintele logopedice au vizat:}

Dezvoltarea respirației prin educarea respirației non-verbale și verbale:

Dezvoltarea respirației non-verbale (educarea echilibrului dintre inspirație și expirație - inspir adânc pe nas cu gura închisă, expirație pe gură);

Dezvoltarea respirației verbale (obținerea unei expirații mai lungi decât inspirația în timpul pronunției; vorbirea în expirațe fără efort și în mod ritmat). 
Dezvoltarea preachizițiilor: structuri senzorio-perceptive, schemă corporală, lateralitate, orientare spațio-temporală

Dezvoltarea abilităților de diferențiere auditiv-verbale

Dezvoltarea abilităților motorii generale și fine.

Un rol deosebit în terapia logopedică l-a ocupat mobilizarea orofacială și desensibilizarea la nivel facial. S-a realizat în mod regulat masaj la nivel facial și masare intraorală folosind periuțe diverse și kitul Z-Vibe și tehnica punctelor motorii propusă de Castillo Moralles. De asemenea, s-a efectuat miogimnastică și terapie miofuncțională prin imitarea în oglindă a exercițiilor propuse de către terapeut. Astfel, copilul poate percepe vizual poziția organelor de vorbire în timp ce se confruntă cu propriul model. În plus, $\mathrm{s}$-au folosit toți analizatorii pentru a percepe mult mai ușor caracteristicile sunetului și pentru a-l emite cât mai acurat (D. a fost încurajată să atingă gâtul adultului când acesta emite sunete; să atingă pieptul adultului când acesta inspiră și expiră puternic; să poată observa pe dosul palmei aerul expirat în timp ce adultul emite sunete precum: $f, v, h, s, s$, etc.).

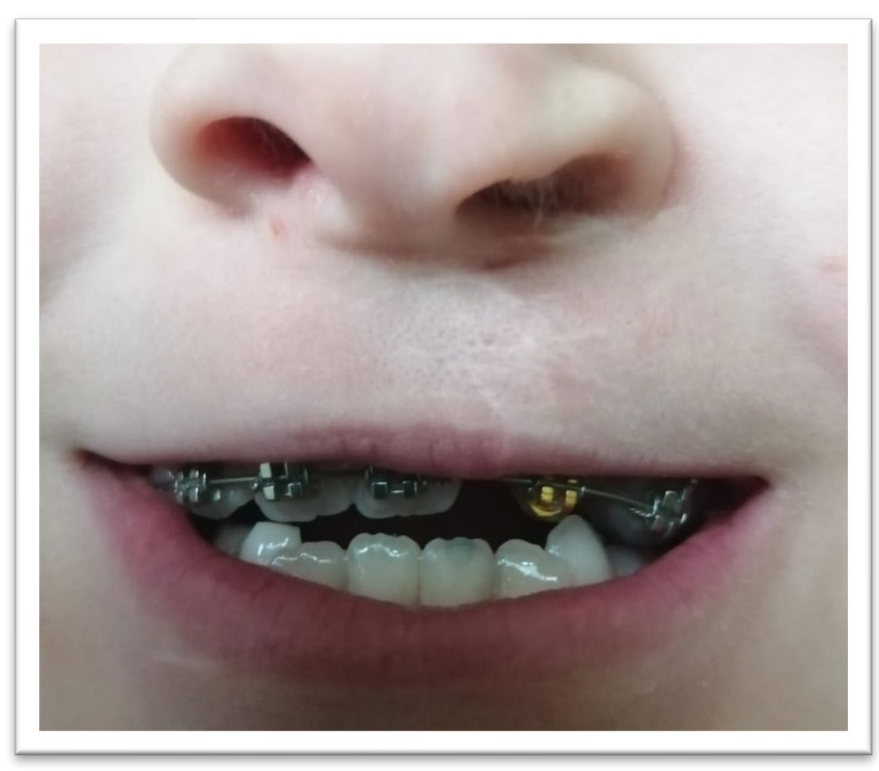

Fig.2: Imagine - Aparat ortodontic fix

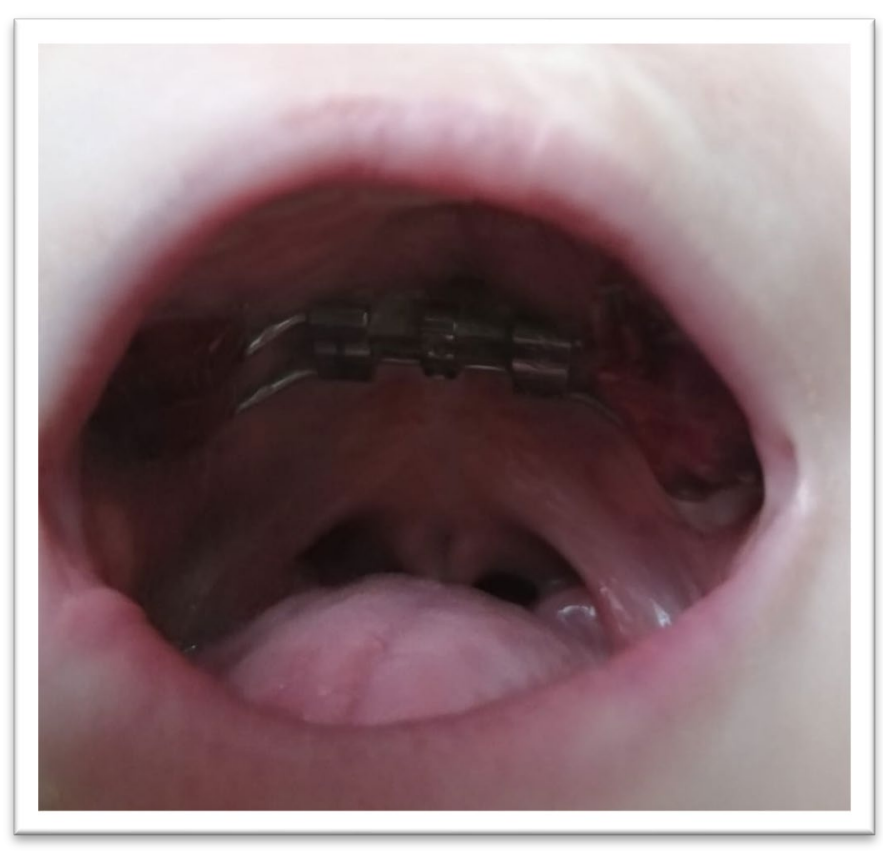

Fig. 3: Imagine - Placă de dilatare transversală fixă

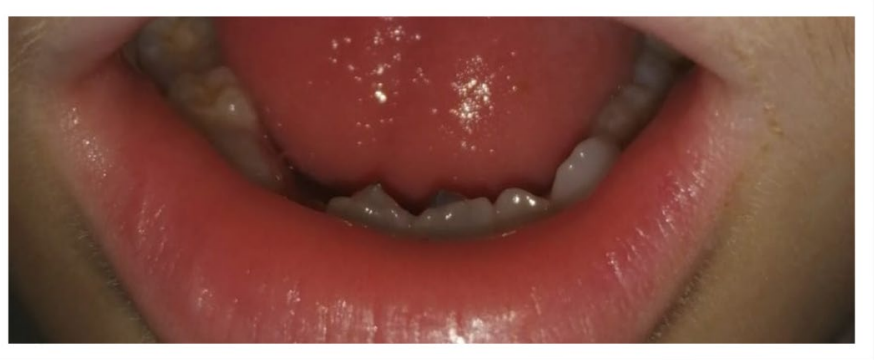

Fig. 4: Imagine „T,Tepi ortodontici” (Tongue tamers/Habit tamers) 


\section{Concluzii}

Durata procesului de recuperare a copilului cu despicătură facio-labiopalatină depinde de mai mulţi factori: nivelul dezvoltării intelectuale; vârsta la care se intervine; o premisă importantă este intervenția cât mai de timpuriu, când plasticitatea neuronală este mai mare; implicarea activă a părinţilor în procesul logopedic (terapia logopedică implică în principal implicarea părinţilor); gradul de implicare a copilului în realizarea activităţilor / exerciţiilor terapeutice.

Pentru înregistrarea succesului în munca logopedică, pe întreaga perioadă de recuperare şi tratament este necesară o strânsă colaborare cu familia copilului şi abordarea unei strategii comune, în privinţa modului de comunicare, a stimulării vorbirii şi a intelectului, a stimulării socializării şi a dorinţei copilului de a comunica, asigurarea unei dezvoltări psihice normale şi prevenirea instalării unor tulburări psihice sau de personalitate.

\section{Bibliografie}

Arosarena, O. A. (2007). Cleft lip and palate: Otolaryngologic Clinics of North America, vol. 40, no. 1, pp. 27-6o.

Bodea Hațegan, C. (2016). Terapia tulburărilor de limbaj. Structurilor deschise, Ed. Trei, București.

Bjork, A. (2007). Sutural growth of the upper face studied by the implant method: European Journal of Orthodontics i82-i88.

Boyne, P. J., Sands, N. R. (1972). Secondary bone grafting of residual alveolar and palatal clefts, Journal of Oral Surgery, vol. 30, no. 2, pp. 87-92.
Burlibaşa, C. (coord) (1999). Chirurgie orală și maxilo-facială, (Ed. aII-a), Ed. Medicală, București

Hurubeanu, L. (2002). Stomatologie şi chirurgie oro-maxilo-facială, Ed. Medicală a Universităţii „Iuliu Haţieganu", Cluj-Napoca.

Guţu, M. (1975). Logopedie, Universitatea Babeș-Bolyai, Cluj-Napoca, Uz intern

Katzel, E. B., Basile, P., Koltz, P. F., Marcus, J. R., Girotto, J. A. (2009). Current surgical practices in cleft care: cleft palate repair techniques and postoperative care, Plastic and Reconstructive Surgery: vol. 124, no. 3, pp. 899-900.

Kirschner, R. E., LaRossa, D. (2000). Cleft lip and palate: Otolaryngologic Clinics of North America, vol. 33, no. 6, pp. 1191-1215.

Kuijpers-Jagtman, A. M. (2006). The orthodontist, an essential partner in CLP treatment, B-ENT, vol. 2, no. 4, pp. 57-62.

Levy-Bercowski, D., DeLeon, E. Jr, Stockstill, J. W., Yu, J. C. (2011). Orthognathic cleftsurgical/orthodontic treatment, Seminars in Orthodontics, vol. 17, no. 3, pp. 197-206.

Meazzini, M.C. (2008). A Cephalometric Intercenter Comparison of Patients With Unilateral Cleft Lip and Palate: Analysis at 5 and 10 Years of Age and Long Term, The Cleft PalateCraniofacial Journal 45(6):654-60

Mercado, A., Vig, K. (2019). Orthodontic Principles in the Management of Orofacial Clefts 
Miloro, M., Larsen, P., Ghali, G. E. (2004). WaitePeterson's Principles of Oral and Maxillofacial Surgery:BC Decker, Ontario, Canada, 2 edition 2004.

Moldovan, I. (2006). Corectarea tulburărilor limbajului oral, Presa universitară clujeană, Cluj Napoca

Mureșan, R. (2015). Anatomia cavității bucale. Recuperarea disfagiei, note de curs

Salyer, K. E. (2001). Excellence in cleft lip and palate treatment, Journal of Craniofacial Surgery, vol. 12, no. 1, pp. 2-5.

Saperstein, E.L., Kennedy, D., Muliken, J.B., Padwa B., (2012).Facial growth in children with complete cleft of the primary palate and intact secondary palate: Oral Maxillofacial Journal 70:e66-e71.

Shaikh, D., Mercer, N. S., Sohan, K., Kyle, P., Soothill, P., (2001). Prenatal diagnosis of cleft lip and palate: British Journal of Plastic Surgery, vol. 54, no. 4, pp. 288-289.

Shetye, P. R., (2012). Presurgical infant orthopedics, The Journal of Craniofacial Surgery, vol. 23, no. 1, pp. 210-211.

Tote, R., Munteanu, S., Pascu, A., Purav, D., Stancu, D., Oruc, V., Komini, E., Melian, G., Zetu, I., (2014). Aspecte clinico-terapeutice ale despicăturilor labio-maxilo-palatine: date din lieratură, Romanian Journal of Medical and Dental Education, vol.3, issue 1, January-June 2014.

Vlachos, C. C. (1996). Orthodontic treatment for the cleft palate patient,
Seminars in Orthodontics, vol. 2, no. 3, pp.197-204.

Wyszynski, D.F. (2002). Cleft Lip and Palate: From Origin to Treatment: Oxford University Press.

http://www.dentalconceptstudio.ro/ro/In forma $\%$ C $8 \% 9$ Bii-pentru-

pacien $\% \mathrm{C} 8 \% 9 \mathrm{Bi} /$ Chirurgieortognat $\% \mathrm{C}_{4} \% 83$ Chirurgieortognat $\% \mathrm{C}_{4} \% 83-272$

https://www.intramed.ro/reabilitareapreoperatorie-sau-pregatirea-fizicainainte-de-operatie/

https://mashpeeortho.com/

https://

play.google.com/store/apps/details?id =ppls.pps.com.ppl

1. Voluntar Asociația Autism Câmpia Turzii Profesor logoped CJRAE, Arad

Email: madalina.orian@gmail.com 


\title{
Studiu privind activitățiile de prevenire a tullburărilor de limbaj în grădinițe
}

\author{
Simona Bianca ROȘCA ${ }^{1}$
}

\begin{abstract}
The present research starts from the idea of preventing language disorders from an early age, given the results of previous research on the effectiveness of early interventions.

Following a preliminary documentation that consisted in the study of Romanian legislation, specialized literature, speech therapy aids, speech therapy software, sites with medical profile and special pedagogy, it was found an insufficient approach to prevention and we wanted to investigate what activities speech therapy teachers consider to be included in the concept of prevention. We also sought to find out to what extent speech therapists take into account the prevention part and what activities they carry out for this purpose. The results were limited and we see them from at least two perspectives: the small group of participants that led to limited data and the absence or quasi-absence of prevention in speech therapy, this being too little described in the literature and outlined as a methodology in school documents. The most common options chosen by language therapists for prevention were to carry out speech therapy activities in prevention groups under the age of 5 and to carry out information activities for educators and parents and only then screening activities
\end{abstract}

Keywords: early intervention, prevention, pre-K programs

\section{Introducere}

\section{Factorii determinanți ai dezvoltării Iimbajului}

Există un acord considerabil, între cercetări, privitor la faptul că cursul dezvoltării limbajului reflectă interacțiunea factorilor în cel puțin cinci domenii: procesare socială, perceptivă, cognitivă, conceptuală și lingvistică. Teoreticienii diferă în accentul și gradul de determinare pentru un anumit domeniu (social, ereditar, etc), dar majoritatea ar fi de acord că fiecare este relevant. Există un număr mare de cercetări care susțin ideea că învățarea limbajului este influențată de multe aspecte ale experienței și capacității umane. Voi menționa câte două descoperiri care surprind esența în fiecare zonă.

\section{Social}

1. Copiii deduc intenția comunicativă a unui vorbitor și folosesc informațiile respective pentru a-și ghida învățarea limbajului. De exemplu, încă de la 24 de luni, aceștia pot deduce doar din tonul emoționat al vocii unui adult și din poziția fizică faptul că un cuvânt nou trebuie să se refere la un obiect care a fost plasat pe masă în timp ce adultul era plecat.(Akhtar N.\&colab., 1996)

2. Mediul verbal influențează învățarea limbii. De la vârste de la unu la trei ani, copii din familiile cu bagaj verbale înalt „profesional” au auzit de aproape trei ori mai multe cuvinte pe săptămână decât copiii din familii cu bagaj verbal „sărac”. Datele longitudinale arată că aceste aspecte prezic scorurile de limbaj la vârsta de 9 ani.(Hart, Risley, 1995)

\section{Perceptual}

1. Percepția sugarului stabilește etapa. Integritatea percepției auditive la vârsta de șase sau 12 luni pot prezice dimensiunea 
vocabularului și complexitatea sintactică la vârsta de 23 de luni.(Trehub SE, 1996)

2. Percepția contează. Copiii cu deficiențe auditive au dificultăți în a-și însuși consoane surde și sonore, în special siflantele și cele greu de citit prin labiolectură. (Leonard, 1992)

\section{Bognitiv}

1. Frecvența afectează rata de învățare. Copiii care aud o proporție neobișnuit de mare de exemple (ex.sinonime) învață acea formă mai repede decât copiii care primesc cuvinte obișnuite.(Nelson \& colab.,1996)

2. „Compromisurile” între diferitele domenii de limbă pot apărea atunci când propoziția totală vizată necesită mai multe resurse mentale decât dispune copilul. De exemplu, copiii fac mai multe erori la forme gramaticale mici, cum ar fi terminațiile verbelor și prepozițiile în propoziții cu sintaxă complexă decât în propoziții cu sintaxă simplă.(Namazi \& Johnston,1997)

\section{conceptual}

1.Termenii relaționali sunt legați de vârsta mentală. Cuvintele care exprimă noțiuni de timp, cauzalitate, locație, dimensiune și ordine sunt corelate cu vârsta mentală mult mai mult decât cuvintele care se referă pur și simplu la obiecte și evenimente.(Johnston Jr.\&Slobin ,1979)

Mai mult, copiii care învață diferite limbi învață să vorbească despre poziții spațiale, în aceeași ordine, în același timp indiferent de artificiile gramaticale ale limbii pe care o vorbesc. (Mc Gregor K. \&colab, 2002)

2. Abilitățile lingvistice sunt afectate de cunoștințele de mediu. Copiii care au dificultăți în a-și aminti un cuvânt cunosc puține despre trăsăturile, mediul obiectului la care se referă cuvântul. (Carr, Johnston, 2001)

\section{lingvistic}

1. Terminațiile verbale sunt indicii către sensul verbului. Dacă , de pildă un verb în engleză se termină în -ing, copiii de trei ani vor decide că se referă la o acțiune actuală ( înot, baie, etc) (Fazio și colab., 1993)

2. Vocabularul actual influențează învățarea nouă. De obicei, copiii mici decid dacă un cuvânt nou se referă la obiect pentru care nu au deja o etichetă. (Clark,1993)

\section{Natura și îngrijitrea}

Acestea sunt doar câteva dintre rezultatele care, luate împreună, vorbesc convingător despre natura interactivă dezvoltării. Copiii vin pregătiți pentru sarcina învățării limbajului cu mecanisme perceptuale care funcționează în un anumit mod și cu atenție finită și capacități de memorie. Aceste sisteme cognitive vor influența, cel puțin, ceea ce se observă în input-ul limbajului și pot fi foarte importante în procesul de învățare. În mod similar, cunoștințele anterioare dobândite prin experiența cu lumea materială și socială oferă bazele timpurii pentru interpretarea limbajului pe care îl aud. Mai târziu, vor folosi și indicii de limbă. Cu toate acestea, cursul de achiziție a limbajului nu este condus exclusiv din interior. Structura limbii care trebuie învățată și frecvența cu care se întâlnește $\mathrm{cu}$ diverse forme (sensuri sau sinonime) va avea, de asemenea un efect. În ciuda dezbaterilor teoretice, pare clar că în abilitățile lingvistice se reflectă cunoștințe și 
capacități din aproape toate domeniile și nu trebuie privite în mod insular.

Un alt factor determinant al dezvoltării limbajului care a fost luat în considerare de către Regina M. și Cusson RNC (2003) a fost nașterea înainte de termen. Eșantionul a fost format din 43 de mame și sugarii lor prematuri care au fost sub 2.000 g și vârsta de gestațiede 36 de săptămâni la naștere. Mai mult de $88 \%$ din eșantion provin din clase sociale inferioare. $70 \%$ din eșantion au fost afro-americani, iar $27 \%$ au fost albi. Bebelușii A fost evaluată dezvoltarea la vârsta de 7, 13 și 26 de luni. Nivelul dezvoltării a fost evaluat folosind scările Bayley ale dezvoltării sugarului, iar limbajul a fost evaluat folosind scările limbajului dezvoltării Reynell.

Autorii au ajuns la concluzia că la vârsta corectată de 26 de luni, dezvoltarea sugarului a fost în limitele normale. Limbajul expresiv și receptiv a fost întârziată în medie de 3 până la 5 luni. Factorii care influențează limbajul includeau durata șederii în spital, greutatea la naștere, scorurile Apgar, iritabilitatea sugarului și reglarea stării la externarea din spital și sensibilitatea maternă.

Aceste cercetări conduc a câteva implicații educaționale.Educatorii și factorii de decizie au ignorat adesea preșcolarii a căror limbaj pare să rămână în urmă față de dezvoltarea în alte domenii, susținând că astfel de copii „întârzie puțin” în vorbire. Dovezile cercetării sugerează în schimb că achiziția limbajului trebuie tratată ca un barometru important al succesului în sarcini integrative complexe. Așa cum tocmai am văzut, de fiecare dată când limbajul „nu reușește” sunt implicate și alte domenii în calitate de cauze sau consecințe. Într-adevăr, studii epidemiologice majore au demonstrat acum că copiii diagnosticați cu tulburări specifice de limbaj la vârsta de patru ani (adică întârzieri în dobândirea limbajului, fără tulburări percetive, motorii sau retardare) prezintă un risc ridicat pentru eșec academic și sănătate mintală la vârsta adultă tânără (Young \& colab. 2002, Beitchman \&colab.,2001)

Bodea- Hațegan,C.,(2016, p.542) notează că " întârzierea limbajului implică raportarea la o normă, la un standard cu privire la etapele achiziției limbajului..." și definește întârzierea în dezvoltarea limbajului ca fiind :"acea categorie patologică ce presupune achiziția defivitară a limbajului, având în vedere normative, tipice, cu privire la dezvoltarea limbajului , achiziție ce poate fi recuperatăpe pacursul perioadei de preșcolaritate (2-6 ani). Cu alte cuvinte, întârzierea în dezvoltarea limbajului propune structurarea limbajului în alte etape, urmând o stadialitate, etapizare, diferită față de stadialitatea tipică în dezvoltarea limbajului." (p.544)

Datele notate de unii cercetători (Law și colab.,2009 și Morgans, 2017) implică faptul că întârzierea vorbirii și a limbajului netratată poate persista la $40 \%-60 \%$ dintre copii și acești copii prezintă un risc mai mare de probleme sociale, emoționale, comportamentale și cognitive la vârsta adultă

\section{Metodologia cercetării}

Cercetarea de față pornește de la ideea prevenției tulburărilor de limbaj de la vârste cât mai timpurii, date fiind 
rezultatele cercetărilor anterioare privind eficiența intervențiilor precoce.

În urma unei documentări prealabile care a constat în studierea legislației românești, a literaturii de specialitate, auxiliare logopedice, softuri logopedice, site-uri cu profil medical și de psihopedagogie specială s-a constatat $\mathrm{o}$ insuficientă abordare a tematicii prevenției și s-a dorit să investigăm ce activități consideră profesorii logopezi a fi cuprinse conceptului de prevenție. De asemenea sa dorit să se afle și în ce măsură profesorii logopezi iau în considerare partea de prevenție și ce activități desfășoară în acest scop.

Cercetarea de față este pur constatativă dar deschide un drum către organizarea muncii logopedice înspre prevenție. Ea are în vedere cunoașterea dinamică a fenomenului de prevenției tulburărilor de limbaj în mediul preșcolar, cât și dimensiunea directiv acțională, de intervenție propriu-zisă, întreprinsă pe căile și cu metodele și mijlocele disponibile educației școlare, cu antrenarea familiei și a altor factori educativi.

La baza acestui demers stă convingerea că, în mare parte manifestările tulburărilor de limbaj oral și scris-citit au la bază abateri nedepistate la timp, lăsate să se adâncească și să se automatizaze, să devină scheme stabile.

Se ia în considerare ideea că remediul acestor situații constă în dezvoltarea laturii educativ- preventive și în activarea resurselor umane și educaționale disponibile, sincronizată cu influențele formative ale altor factori cointeresați în procesul prevenției tulburărilor de limbaj oral și scris-citit din diverse cauze.

\section{Obiectivele cercetării}

\section{Obiective de cunoaștere:}

Identificarea direcțiilor de prevenție specifice domeniului terapiei tulburărilor de limbaj și comunicare actuale prin actualele forme de organizare;

Identificarea celor mai adecvate metode și mijloace care permit realizarea prevenției în domeniul logopedic;

\section{Ipoteze}

Există o relație între vechimea profesorilor logopezi și gradul în care aceștia consideră acoperirea nevoilor de dezvoltare a preșcolarilor de către curriculum preșcolar;

Numărul opțiunilor privind metodele de prevenție cu specific logopedic considerate ca fiind circumscrise conceptului de prevenție crește proporțional cu vechimea în domeniu;

Există o relație între vechimea respondenților și gradul în care consideră că sunt utile activitățile de prevenție a tulburărilor de limbaj la nivel preșcolar;

Există o relație între gradul în care profesorii logopezi consideră utile activitățile logopedice de prevenție și numărul de activități de prevenție desfășurate cu părinții anual;

Există o relație între gradul în care profesorii logopezi consideră utile activitățile logopedice de prevenție și numărul de activități metodice și de prevenție desfășurate $\mathrm{cu}$ educatoarele anual;

\section{Instrumente}


S-a folosit ca metodă de cercetare ancheta pe bază de chestionar. În urma consultării mai multor profesori logopezi a fost conceput un chestionar cu 10 itemi care cuprind atât date demografice cât și informații privitoare la problematica logopedică a prevenției.

Chestionarul a fost administrat exclusiv online prin diseminarea lui către logopezii CJRAE din țară.

Pentru a exclude posibilitatea de a răspunde la chestionar alte persoane necalificate în domeniu primul item a investigat însuși calitatea de logoped a respondenților.

Cel de-al doilea item vizează vechimea în domeniul logopediei a respondenților.

Al treilea item a consultat profesorii logopezi cu privire la curriculum preșcolar actual în raport cu nevoile preșcolarilor de dezvoltare a limbajului, printr-o scară graduală de la 1 la 5 în funcție de măsura în care consideră că actualul curriculum preșcolar acoperă nevoile de dezvoltare a limbajului la preșcolari .

Itemul 4 a fost sub formă de răspuns multiplu și investighează ce tip de activități sunt considerate de către profesori logopezi ca putând fi circumscrise conceptului de prevenție cuprinzând screeningul și activitățile de informare și intervenție.

Gradul în care logopezii consideră că sunt utile activitățile de prevenție a tulburărilor de limbaj a fost evaluat prin itemul al 5-lea care este sub formă de scară graduală de la 1- deloc utile la 5 foarte utile.

Privitor la cea mai adecvată formă de organizare a activităților de prevenție itemul 6 a cuprins două opțiuni actvități la grupă desfășurate de către educatoare sau activități săptămânale cu obiective de prevenție desfășurate de logopezi.

Principalele moduri de organizare a activităților de prevenție de către profesorii logopezi au fost colectate prin întrebarea cu răspuns deschis de la itemul 7.

Itemul 8 solicită participanților la studiu propuneri de activități de prevenție.

Itemii 9 și 10 investighează media numărului de activități anuale logopedice de informare adresate părinților preșcolarilor și educatoarelor ;

\section{Lotul de participanți}

Lotul luat în studiu a avut 35 de participanți, profesori logopezi din rețeaua școlară. Distribuția participanților în raport cu vechimea lor în domeniul logopediei a fost următoarea : $4 \%$ dintre participanți aveau o vechime de o-5 ani, 29\% 5-10 ani, 25\% 10-20 ani și $42 \%$ au avut o vechime peste 20 de ani. Cei mai mulți participanți au avut o vechime de peste 10 de ani în domeniul logopediei, astfel vom interpreta contribuția lor ca fiind relevantă, aceștia fiind în cunoștință de cauză datorită acestei experiențe acumulate.

Datele obținute prin prelucrarea statistică a datelor au fost interpretate cantitativ, calitativ și omparativ, încercându-se corelarea diverselor variabile : vechime, opțiuni,etc Vor fi utilizate metode de analiză a datelor mixte: cantitative și calitative.

\section{Rezultatele obținute}

Referitor la măsura în care participanții consideră că actualul curriculum preșcolar acoperă nevoile de dezvoltare a limbajului 
la preșcolari , majoritatea rezultatelor s-au situat la medie pe o scară graduală de la 1 reprezentând în mică măsură la 5 reprezentând în mare măsură.. 21 de participanți, reprezentând $60 \quad \% \quad$ au considerat că actualul curriculum acoperă nevoile de dezvoltare a limbajului preșcolarilor. La al 4-lea item au fost sondați participanții cu privire la activitățile pe care le consideră a fi circumscrise conceptului de prevenție. Aceștia au putut bifa toate variantele aplicabile.Aceștia au avut de ales una sau cel mult 6 dintre variantele ilustrate în graficul Nr. 1 :

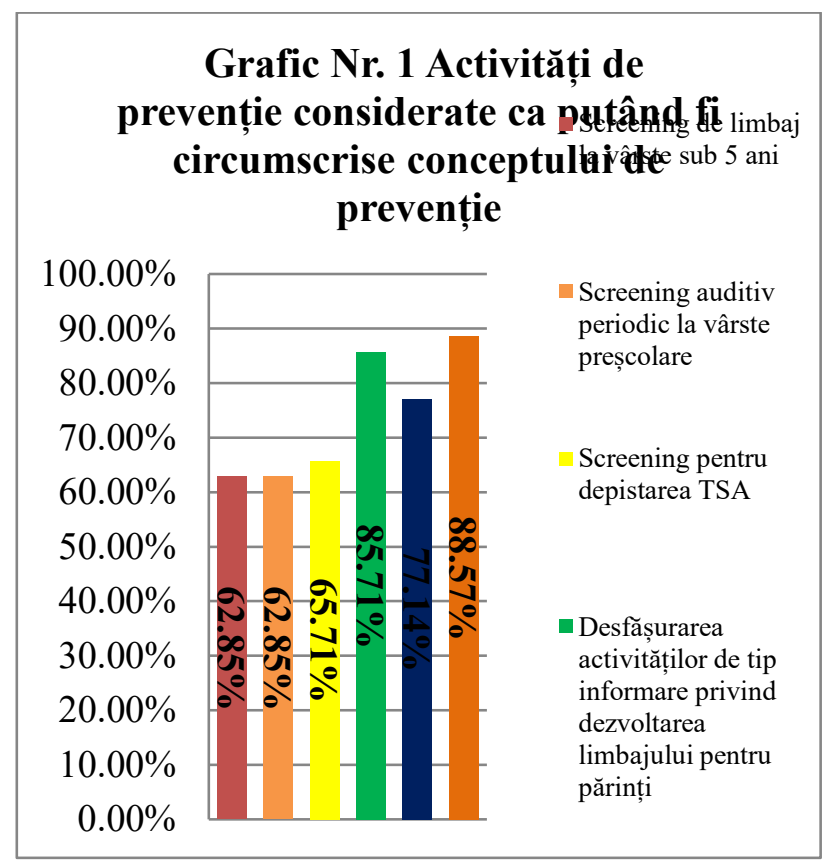

Graficul de mai sus reflectă procentele obținute pentru fiecare variantă de răspuns. Cele mai frecvente opțiuni au fost desfășurarea de activități logopedice în grupuri de prevenție la vârste sub 5 ani și desfățurarea activitîților de tip informare pentru educatoare și părinți și doar apoi activitățile de screening.

Utilizând o scară graduală de la 1 la 5 participanții au fost solicitați să evalueze utilitatea activităților de prevenție la vârsta preșcolară. Rezultatele au arătat că peste $85 \%$ dintre participanți consideră activitățile de prevenție ca fiind foarte utile.

Organizarea activităților de prevenție pot avea numeroase forme de organizare. În legătură cu acestea s-au luat principalele două ca opțiuni ale itemului 6 :

Activitățile zilnice desfășurate de educatoare cu grupa ;

Activități săptămânale cu obiective de prevenție desfășurate de logopezi cu grup de copii selectați anterior.

Un procent de $68,57 \%$ dintre respondenți consideră că activitățile desfășurate de logopezi pentru copiii sub 5 ani sunt mai potrivite pentru prevenția tulburărilor de limbaj oral și scris-citit.

Itemul 7 al chestionarului administrat profesorilor logopezi a fost o întrebare cu răspuns liber.

Vom cita câteva dintre răspunsurile profesorilor.

Profesor logoped cu vechime peste 20 ani : "Realizez activitati directe cu preșcolarii de la 4 ani și consiliez părinții copiilor. "

Profesor logoped cu vechime peste 20 ani : "Informarea parinților privind dezvoltarea limbajului la copiii, pregatirea lor în cadrul grupurilor de părinti Organizarea activitaților interactive pentru educatori Activități pentru toți copiii din grădinita Activități regulate de gimnastică specială și de dans pentru preșcolari. “

Din aceste răspunsuri se poate observa faptul că nu există o metodă unitară de intervenție preventivă ci mai degrabă una proprie de organizaree a muncii logopedice. 
La întrebarea de la al 8-lea item "Ce activități a tulburărilor de limbaj la vârsta preșcolară ați propune ?" răspunsurile au avut mai multe direcții care au vizat direct sau indirect beneficiarii preșcolari ai serviciilor logopedice.

Prima direcție și cea mai frecventă opțiune de desfășurare a activităților logopedice preventive a fost revizuirea curriculumui preșcolar și instruirea educatoarelor în scopul desfășurării de scurte activități cu obiective specifice zilnice cum ar fi :

- exerciții de respirație, dezvoltarea aparatului fonoarticulator;

-jocuri pentru dezvoltarea conștiintei fonologice și a auzului fonematic și alte jocuri de antrenare a atenției și memoriei auditive cu onomatopee și memorare de poezii;

-activități si jocuri muzicale cu text și cânt, jocuri de rol, povestiri, repovestiri, etc pe grupuri mici de copii si individuale;

- dezvoltarea lateralității, a orientării in spațiu, etc.

Acest răspuns a fost cel puțin surprinzător deoarce majoritatea profesorilor au considerat că actualul curriculum preșcolar acoperă în mare măsură nevoile de dezvoltare a limbajului, totuși se poate considera că pregătirea metodică a educatoarelor în sensul identificării și prevenirii tulburărilor de limbaj este insuficientă. A doua direcție, a fost desfășurarea de activități de screening de limbaj la grupe mici și mijocii și cuprinderea preșcolarilor în grupuri de prevenție desfășurând activități cu aceleași obiective ca cele de mai sus. A treia direcție și cea mai puțin frecventă a fost informarea și cooptarea părinților în activitățile de prevenire a tulburărilor de limbaj. Interesant de menționat ar fi faptul că rareori au fost oferite de același respondent mai multe opțiuni din cele trei direcții menționate simțindu-se o divergență de opinii și absența unei viziuni globale și unitare a conceptului de prevenție.

$\mathrm{Al}$ 9-lea item care a consultat participanții privind numărul de activități organizate pentru părinți defășurate cei mai mulți respondenți $(60 \%)$ organizează mai multe întâlniri anuale pentru părinți cu scop de informare și îndrumare.

Privitor la ultimul item, acesta a privit numărul activităților metodice organizate de către profesorii logopezi pentru educatoare anual. Din răspunsurile la acest item rezultă că aproximativ $37 \%$ dintre profesori reușesc să organizeze cel mult o înâlnire metodică cu educatoarele iar în jur de $55 \%$ organizează două sau mai multe întâlniri.

\section{Testarea ipotezelor}

\section{Ipoteza 1}

Prin testarea ipotezei I concluzionăm că profesorii nu par să considere diferit gradul de acoperire a nevoilor de dezvoltare a preșcolarilor de către curriculum preșcolar dacă au o vechime mai mică sau mai mare ci răspunsurile se distribuie oarecum uniform.

\section{Ipoteza 2}

Pentru a testa această ipoteză s-a randomizat grupul de subiecți cu vechime mai mare de 10 ani după criteriul par / impar și constituit două loturi egale. S-a cuantificat numărul opțiunilor respundenților și apoi s-au comparat datele. S-a obținut un coeficient de 
corelație negativ $\mathrm{r}=-0,18295, \mathrm{p} \leq \mathrm{0}, 05$. Deși coeficientul de corelație este mic se poate observa că ipoteza emisă nu este validă și că există o tendință opusă celei enunțate în ipoteză.

\section{Ipoteza 3}

Prin corelarea variabilei vechime și gradul în care se consideră utilitatea activităților logopedice preventive s-a obținut un coeficent de corelație negativ care indică tendința inversă dar insuficient de mare pentru validarea ipotezei, $\mathrm{r}=-0,105056058$, $\mathrm{p} \leq 0,05$.Astfel nu se poate spune că percepția utilității activităților de prevenție diferă în funcție de vechime și că există o tendință inversă : cu cât vechimea a fost mai mică utilitatea prevenției a fost considerată mai importantă.

\section{Ipoteza 4}

Prin corelarea celor două variabile s-a obținut un coeficient de corelație negativ $\mathrm{r}=-0,188823063, \mathrm{p} \leq \mathrm{0}, 05$ însă coeficientul obținut fiind foarte mic se poate spune că nici de data aceasta nu se poate valida ipoteza ci doar putem observa faptul că nu există o tendință direct proporțională ci una inversă.

\section{Ipoteza 5}

Coficientul de corelație obținut și de această dată este neconcludent fiind prea mic $r=0,097112753 \mathrm{p} \leq 0,05$, astfel nu se poate valida ipoteza.

\section{Concluzii}

Se interpretează aceste rezultate din cel puțin două perspective: lotul mic de participanți care a condus la obținerea unor date limitate și absența sau cvasiabsența prevenției în logopedie, aceasta fiind prea puțin descrisă în literatură și conturată ca metodologie în documentele școlare.

Studiul de față dechide orizontul spre cercetări și intervenții experimentale în vederea implementării politicilor de prevenție ca prioritate în abordarea copiilor cu tulburări de limbaj.

\section{Bibliografie}

Akhtar N, Carpenter M, Tomasello M. (1996). The role of discourse novelty in early word learning. Child Development;67(2):635-645.

Beitchman JH, Wilson B, Johnson CJ, Atkinson L, Young A, Adlaf E, Escobar M, Douglas L (2001). Fourteen year follow-up of speech/languageimpaired and control children: psychiatric outcome. Journal of the American Academy of Child and Adolescent Psychiatry; 40(1): p.75- 82.

Bodea Hațegan C., (2016). Logopedia, Terapia tulburărilor de limbaj structuri deschise, Ed. TREI, București ; p.542617

Carr L, Johnston J.(2001). Morphological cues to verb meaning. Applied Psycholinguistics;22(4): p.6o1-618.

Clark EV. (1993). The lexicon in acquisition. New York, NY: Cambridge University Press

Fazio BB, Johnston JR, Brandl L. (1993). Relation between mental age and vocabulary development among children with mild mental retardation. American Journal of Mental Retardation; 97(5): p.541-546.

Hart B, Risley TR. (1995). Meaningful differencesin the everyday experience 
of young American children. Baltimore, Md: P.H. Brookes

Johnston JR, Slobin DI. (1979). The development of locative expressions in English, Italian, Serbo-Croatian and Turkish. 6(3): p.529-545. Journal of Child Language https://www.semanticscholar.org/pap er/The-development-of-locativeexpressions-in-English\%2C-JohnstonSlobin/721df2634ad40251bao7d8oo5fed 5b25ac4631cf

Law J, Rush R, Schoon I, Parsons S. (2009). Modeling developmental language difficulties from school entry into adulthood: Literacy mental health and employment outcomes. J Speech Lang Hear Res. ;52: p.1401-16. Consultat în 26 o5 2020 https://pubmed.ncbi.nlm.nih.gov/1995 1922/

Leonard L. (1992). The use of morphology by children with specific language impairment: Evidence from three languages. In: Chapman RS, ed. Processes in language acquisition and disorders. St. Louis, Mo: Mosby Year book; p.186-201.

McGregor K, Friedman RM, Reilly RM, Newman RM. (2002). Semantic representation and naming in young children. Journal of Speech, Language, and Hearing Research ;45(2):p .332346.

Morgans A, Ttofari Eecen K, Pezic A, Brommeyer K, Mei C, Eadie P, et al, (2017). Who to refer for speech therapy at 4 years of age versus who to watch and wait. J Pediatr. ;
Namazi M, Johnston J. (1997). Language performance and development in SLI. Paper presented at: Symposium for Research in Child Language Disorders; Madison, Wis.

Nelson KE, Camarata SM, Welsh J, Butkovsky L, Camarata M. (1996). Effects of imitative and conversational recasting treatment on the acquisition of grammar in children with specific language impairment and younger language-normal children, Journal of Speech and Hearing Research;39(4): p. $850-859$

Regina M., Cusson RNC, (2003). Factors Influencing Language Development in Preterm Infants, Journal of Obstetric, Gynecologic \& Neonatal Nursing ,Vol.32, Nr. 3, 05, p.402-409 consultat în 18032020

Trehub SE, Henderson JL.(1996). Temporal resolution and subsequent language development; Journal of Speech and Hearing Research 39(6):p.1315-1320.

Young AR, Beitchman JH, Johnson C, Douglas L, Atkinson L, Escobar M, Wilson B. (2002). Young adult academic outcomes in a longitudinal sample of early identified language impaired and control children.; Journal of Child Psychology and Psychiatry and Allied Disciplines 43(5): p.635-645.

1. Profesor, CJRAE Mureș,

E-mail: biancarosca@yahoo.com 


\title{
Diminuarea dificultāțillor de predare-învāțare în sistemul on-line
}

\section{Oana PREDA ${ }^{1}$}

\begin{abstract}
The COVID-19 pandemic that resulted in a shift towards on-line teaching and learning resulted in countless difficulties concerning the access to efficient education, especially in the case of children from families with a lesser-endowed socio-economic and cultural background, or children with learning problems, with ADHD or various disabilities (visual or healing impairment, intellectual disabilities, autism spectrum disorders, etc.). Moreover, even pupils who actually have technical access to the new teaching-learning system run the risk of losing their motivation for learning.

The efficient activity of and the results obtained by many teachers whose approach has been successful have shown the efficiency of integrated curricula whose teaching tasks are structured in learning sequences and whose testing patterns are personalized. By putting into practice, the principle of cognitive motivation development through an interactive process of teaching and learning that relies on structured learning sequences and employs personalized assessment techniques, reaching formative pedagogical objectives becomes possible even in the on-line teaching-learning system.
\end{abstract}

Keywords: online teaching system, online learning, motivation for learning, interactive process, structured learning sequences, personalised assessment.

Pandemia cauzată de COVID-19 a dus la trecerea în sistemul de predare-învățare on-line, ceea ce a creat numeroase dificultăți de acces la o reală educație mai ales pentru copiii proveniți din familii cu un statut socio-economic şi cultural scăzut. Mulți elevi din mediul rural sau din oraşe care nu dispun de tablete, computere sau o infrastructură de acces la internet adecvată sunt, de fapt, excluşi din sistemul de predare-învățare on-line.

Problemele dificil de surmontat create de sistemul on-line sunt mai mari la elevii cu dificultăți de învățare, cu ADHD şi la cei cu diferite dizabilități (de auz, de vedere, intelectuale, tulburări din spectrul autist etc.).

Pe fondul sistemului de predare on-line există riscul scăderii pronunțate a motivației învățării, chiar şi la elevii care din punct de vedere tehnic au acces la acest sistem instructiv-educativ on-line.
Tocmai de aceea se impune ca profesorii şi părinții elevilor să prevină în primul rând scăderea motivației învățării. Stimularea motivației este o premisă importantă pentru participarea conștientă şi activă a elevilor la învățarea on-line.

1. Rolul obiectivelor din domeniul afectiv, motivaţional şi cognitiv în predarea online

Pentru integrarea şcolară a copiilor şi tinerilor in sistemul on-line este necesar să se asigure o convergenţă a numeroşi factori: socio-economici şi culturali familiali, infrastructură a şcolilor, climat educaţional, strategii psihopedagogice şi psihologice de incluziune şcolară, stimularea motivaţiei pentru învăţare, aplicarea teoriei inteligențelor multiple, curriculum adaptat, strategii didactice activizante şi evaluare formativă. 
Lipsa sau insuficienta motivaţie pentru învăţarea şcolară poate să fie determinată de atitudinea indiferentă sau chiar ostilă pentru actul educaţional şcolar în sistemul on-line, manifestată de unii părinţi care au o situaţie economică şi culturală precară şi care neglijează dezvoltarea personalităţii copiilor. În astfel de cazuri, pe langă măsurile economico-sociale luate pe baza politicii de combatere a sărăciei, se impune o intervenţie educativă timpurie pentru copiii proveniţi din familii defavorizate, prin implicarea mediatorului şcolar şi a profesorilor de sprijin pentru consilierea părinţilor şi elevilor.

Programele de „Educaţie remedială” şi de stimulare cognitivă care trebuie concepute personalizat în sistemul de predareînvățare on-line sunt utile pentru prevenirea şi combaterea abandonului şcolar. Dar se știe că inteligența este pusă în funcţie şi orientată spre anumite scopuri de factorii emotiv-activi ai personalităţii şi că în structura aptitudinii şcolare alături de factorii intelectuali fiinţează şi factori nonintelectuali, în rândul cărora cei motivaţionali şi afectivi deţin o pondere însemnată.

Desigur, motivaţia intrinsecă a învăţării se formează mai greu şi nu la toţi elevii, dar emoțiile legate de cunoaştere şi diverse trebuinţe pot fi stimulate şi dezvoltate la niveluri care să permită valorificarea potenţialului cognitiv real al elevilor. Transpunerea în fapt a principiului învăţării prin acţiune şi a principiului stimulării şi dezvoltării motivaţiei cognitive facilitează atingerea unor obiective didactice formative (Preda, 2009 a, p. 111-140).

Ỉn strânsă interrelaţie cu crearea optimum-ului motivaţional în condițiile predării on-line, fiecare profesor va urmări dezvoltarea unor stări afective stenice, care să reducă anxietatea unora dintre elevi, iar pe fondul echilibrului afectiv să se clădească atracția faţă de conținutul disciplinei şcolare predate. Pornind de aici, pe baza strategiilor didactice activizante, a unor tehnici motivogene, se poate dezvolta plăcerea de a învăța, curiozitatea, încrederea în capacităţile cognitive, bucuria succesului, bucuria descoperirii/redescoperirii soluţiilor unor probleme, a unor reguli, principii etc.

Substructurile psihice afective şi motivaţionale necesare învățării sunt atât premise, cât şi consecințe ale atingerii obiectivelor cognitive, concepute în desfăşurarea lor procesuală, inclusiv a celor operaţionalizate. Pentru atingerea obiectivelor formative este necesar ca profesorul să stimuleze emoţiile şi sentimentele cognitive ale elevilor, inclusiv prin adaptarea curriculară pentru sistemul on-line şi aplicarea unor programe de învățare remedială.

\section{Stimularea motivației învățării in contextul predărifi on-line}

Predarea în sistemul on-line impune remodelări ale predării-învațării şi ale programului de evaluare, precum şi întăriri pozitive în consens cu particularităţile psihosociale ale elevilor şi cu cerinţele curriculare. În aceste condiţii, măiestria pedagogică îşi spune cuvântul, profesorul bun fiind capabil de a stârni curiozitatea elevilor prin „elemente-surpriză” incluse în demersul didactic (filme, imagini, scheme relevante pentru tema care s-a abordat).

Instruirea interactivă în sistem on-line face posibilă organizarea unor activităţi în 
care se întrepătrund caracteristicile programelor educaţionale cu reprezentările, cunoştinţele empirice, dorinţele şi preocupările elevilor. În actuala paradigmă a design-ului educațional in sistemul on-line, activitatea de predare-învăţare trebuie sa fie axată pe achiziţia unor competenţe tot mai complexe şi variate: cognitive, afectivmotivaţionale şi nu doar pe asimilarea unor informaţii.

Mai mulţi cercetători (Ausubel, Robinson, 1981; Wigfield, Eccles şi Rodriguers, 1998, p. 73-108; Laveault, Leblanc şi Lerou, 1999, p. 81- 98) au subliniat faptul că sporirea eficienței procesului de predare-învăţare şi a autoreglării învăţării şcolare se poate realiza pe baza interacţiunii între procesele cognitive, metacognitive şi determinanţii moţivaţionali. În acest sens, este util să se ia în considerare următoarele aspecte psihopedagogice care contribuie la dezvoltarea motivaţiei şcolare menționate de mai mulți cercetători (Ausubel, Robinson, 1981; Preda 2009 b, p.137-140) :

Acceptarea unui punct de vedere realist privind aspectele reale ale funcţionalităţii motivaţiei elevilor. Profesorii trebuie să accepte că motivaţia extrinsecă şi motivația intrinsecă pot duce - prin întrepătrunderea lor - la creşterea randamentului şcolar.

Evaluarea motivelor învăţării. În cazul în care unui elev nu i se poate capta atenţia şi interesul, profesorul trebuie să detecteze şi să evalueze exact structura şi funcţionalitatea sistemului motivaţional, emoţiilor şi sentimentelor cognitive ale elevului respectiv, raportându-le la cerințele sarcinilor didactice.
Dezvoltarea impulsului cognitiv, pe baza stimulării şi orientării trebuinței de activism şi a trebuinţei de explorare, paralel cu stimularea şi dezvoltarea emoţiilor şi sentimentelor cognitive (curiozitatea, mirarea, îndoiala, bucuria descoperirii).

Punerea în funcţiune a unui nivel adecvat al motivaţiei. Cercetările au demonstrat că forţa mobilizatoare şi eficienţa optimumului motivaţional sunt determinate de trebuinţa de performanţă şi nivelul de aspiraţie al elevului, de capacitatea sa de autocunoaştere şi de evaluarea adecvată a dificultăţilor reale ale sarcinilor didactice. Motivaţia optimă scurtează timpul necesar învăţării, inclusiv la elevii cu ritm mai lent, la care prin activizarea proceselor cognitive se antrenează şi ritmul învățării.

Utilizarea predarii pe grupe de nivel. Elevul poate fi determinat să intre în „competiţie” cu propriile sale realizări anterioare.

\section{strategif ulidactice favoralille prenărit- învătărifi in sistemul on-lïne}

Bunele practici ale profesorilor au demonstrat că în sistemul de predare online sarcinile didactice care sunt structurate pe secvențe de învățare şi pe utilizarea unor teste de cunoştințe lasă libertatea alegerii de către elevi a unor itemi suplimentari, gradual mai complecşi, pe lângă itemii obligatorii. În aceste condiţii se antrenează şi se dezvoltă trebuinţa de performanță şi nivelul de aspiraţie al elevilor.

În sistemul predării-învățării în sitemul on-line, programele curriculare integrate şi proiectele educative personalizate pot viza competențele care trebuie urmărite 
cu precădere pentru fiecare copil, vizând zona proximei dezvoltări a substructurilor cognitive, pe un fond motivaţional-afectiv stenic.
Conținuturile disciplinelor, strategiile didactice şi programele personalizate de intervenţie educativă în sistemul on-line trebuie structurate pe secvenţe de învăţare (Tabelul 1).

Tabelul 1.Avantaje ale utilizării unui program structurat pe secvențe de învățare

\section{Asigurarea unui mediu stimulativ}

\begin{tabular}{ll}
\hline Avantaje pentru elev & Avantaje pentru profesor \\
\hline suscită interesul; & prezintă informaţia în mod atractiv, corespunzător \\
incită la experimentare în variante diferite; & nivelului de pregătire al copilului; \\
$\begin{array}{l}\text { activitatea de învătare se poate desfășura şi pe } \\
\text { baza jocurilor didactice, a unor filme, imagini } \\
\text { relevante. }\end{array}$ & mobilizarea adecvată previne activismul redus al \\
unor elevi.
\end{tabular}

Creșterea graduală a dificultății secvențelor de învățare

\begin{tabular}{l}
\hline Avantaje pentru elev \\
repetă secvența în variante modificate până la \\
însuşirea completă a informației; \\
revine la secvențele anterioare, permițând reluarea \\
traseului percepție $\rightarrow$ reprezentare $\rightarrow$ noțiune; \\
permite utilizarea transpunerii în cuvinte şi a \\
utilizării unor simboluri care mediază \\
interiorizarea acțiunilor obiectuale.
\end{tabular}

Avantaje pentru profesor

recurge la activități adecvate particularităților

individuale, respectând ritmul de lucru al

copilului;

sesizează mai rapid ceea ce nu a înțeles copilul și

revine la secvențe mai uşoare sau în variante mai

simple

acțiunea efectivă însoțită de verbalizare duce la consolidarea conţinutului obiectual în variante de joc și învăţare.

Restructurarea şi transferul informaţiilor se realizează mult mai uşor şi mai rapid

Avantaje pentru elev Avantaje pentru profesor

este solicitat să caute rezolvări în situaţii variate; reţine mai uşor elementele esenţiale şi poate recurge la generalizări;

este stimulat să recurgă la raţionamente.

mobilizează adecvat capacitatea de memorare şi transfer de cunoştinţe;

solicită anticiparea şi apelul la situaţii virtuale pe bază de raţionamente.

\begin{tabular}{ll}
\hline Suportul afectiv şi motivaţional adecvat & \\
\hline Avantaje pentru elev & Avantaje pentru profesor \\
\hline trăieşte succesul şi se simte provocat pentru a & $\begin{array}{l}\text { evaluarea mai uşoară a gradului de stăpânire a } \\
\text { noţiunilor/cunoștințelor; } \\
\text { accepta sarcini mai dificile; }\end{array}$ \\
$\begin{array}{l}\text { revenirea la o secvenţă anterioară găsind un feed- } \\
\text { back adecvat în situațiile în care soluţiile nu pot fi } \\
\text { contestate ori puse la îndoială. }\end{array}$ & $\begin{array}{l}\text { copilului; } \\
\text { permite deprinderea copilului cu autoevaluarea } \\
\text { cunoștințelor }\end{array}$ \\
\hline
\end{tabular}

Pentru construirea instrumentelor de gândire, cercetătorii (Tardif,1970; Perraudeau, 1996) consideră că în proiectarea demersului de predare centrat pe stimularea cognitivă trebuie să se țină seama de următoarele cerințe:
- proiectarea strategică a sarcinilor şi informațiilor de învățat, ceea ce implică atenţia, anticiparea şi verificarea din partea elevului, iar din partea profesorului este necesară specificarea 
tipului de ghidaj şi a modului de derulare a lecţiilor prin secvenţe de învăţare structurate logic;

- asigurarea unei autoreglări cognitive cu centrare pe sarcină;

- materialul de învățat prezentat elevului trebuie să faciliteze centrarea pe sarcină şi nu pe date irelevante;

- să fie încurajată autoevaluarea;

- să existe o fază de transfer între sarcina efectuată şi alte sarcini şcolare.

- evaluarea cunoștințelor să fie predominant formativă.

În sistemul de predare on-line, este util ca profesorii să țină seama de ideile lui Bruner (1970, p. 41), care arată că prin activizarea elevului, procesul de instruire asigură participarea sa conştientă la asimilarea cunoștințelor şi utilizarea acestora în diferite contexte: „A instrui pe cineva nu este o chestiune de înmagazinare de rezultate (memorare de informaţii), ci presupune a-l învăţa să participe la procesul care face posibilă crearea de cunoştinţe; nu predăm o materie oarecare pentru a produce mici biblioteci vii în acea materie, ci pentru a-l face pe elev să gândească el însuşi şi să ia parte la procesul de creare a cunoştinţelor. Cunoașterea este un proces, nu un produs."

$\mathrm{O}$ consecinţă ce rezultă din teoria lui Bruner se referă la faptul că pentru eșecul şcolar al unor elevi, pe lângă lipsa interesului și motivaţiei şcolare, există cel puţin două explicaţii de nuanţă pedagogică:

a) Disciplinele pe care trebuie să le parcurgă elevii nu sunt predate într-o manieră care să satisfacă modalitatea de reprezentare a lumii şi de cunoaştere specifică fiecărui elev (activă-obiectuală, iconică, simbolică)

b) În proiectarea şi implementarea procesului de instruire se ignoră dimensiunea culturală a învăţării (există probleme şi modalități de soluţionare a acestora tipice unei culturi sau alteia). Prin urmare, recomandarea lui Bruner este ca predarea unei discipline să se facă astfel încât să se pornească de la modalitatea de gândire prin care operează copilul.

Procesul de învăţământ, prin modul de structurare a informaţiei, trebuie să evidenţieze şi să dezvolte operaţiile cognitive cerute de situațiile-problemă, iar activitatea cognitivă trebuie analizată în conformitate cu strategia sau regulile cu ajutorul cărora informaţia este organizată, transformată, manipulată şi reprezentată mintal pentru a da naştere la o informaţie nouă. Se desprinde de aici ideea cu privire la structurarea curriculum-ului în spirală: învăţarea şi apoi reluarea unor concepte, principii și strategii rezolutive $\mathrm{cu}$ o mai mare complexitate la nivelurile şcolare superioare.

\section{Bibliografie}

Ausubel, P.D., Robinson, G.F. (1981). Învăţarea în şcoală. O introducere în psihologia pedagogică. București E.D.P.

Bruner, J. (1970).Pentru o teoriea instruirii.București: E.D.P.

Laveault, D., Leblanc, R., Leroux, J. (1999). Autorégulation de l'apprentisage scolaire: interaction entre processus métacognitifs et déterminants de la motivation. În: C. Depover, B. Noël (Eds.) L'évaluation des compétences et 
des processus cognitifs. Paris, Bruxelles: De Boeck \&Larcier: p. 81- 98.

Perraudeau, M. (1996). Les méthodes cognitives. Apprendre autrement à l'école. Paris: Armamd Colin.

Preda, V. (2009 a). Principiile didacticii în viziunea teoriilor constructiviste. In : M. Ionescu, M. Bocoş (coord.).Tratat de didactică modernă.Pitești, Editura Paralela 45 : 111-144.

Preda, V. (2009 b). Obiectivele procesului de predare-învăţare.In : $\mathrm{M}$. Ionescu, M. Bocoş (coord.).Tratat de didactică modernă.Pitești, Editura Paralela 45 : 145-170.
Tardif, J. (1997). Pour un enseignement stratégique. L'apport de la psychologie cognitive. Montréal: Les Editions Logiques.

Wigfield, A., Eccles, J.S., Rodriguers, D. (1998). The development of children's motivation in school contexts. Review of Research in Education, 23: 73-118.

1. Profesor psihopedagog. Şcoala Gimnazială Specială CRDEII Cluj-Napoca

Email: oana preda2004@yahoo.com 


\title{
Rolul implicării parentale în procesul de intervenție logopedică
}

\section{Lucia BOTEZAT ${ }^{1}$}

\begin{abstract}
This research aims to extend and adapt the therapy techniques, specific to the speak and language disorders domain, for their use in the child's family environment. The main subjects of the research are the parents of the children diagnosed with speaking problems.

By encouraging the parent's active participation within the logopedic therapy, it is intended to teach them, so that they could continue the therapy in the child's every day life.

Moreover, the therapeutic collaboration between the speech therapist, the child and the parents allow to valorise the observations made by the parents related to the child environment and every day life, completing the information obtained by the therapist during the complex evaluation of the child. Using this exhaustive information, the therapist is able to propose an intervention program that is personalised to the child's needs.

Furthermore, in the context of the recent changing of the work paradigm, when the therapy sessions are conducted in the format of teletherapy, the collaboration and the support offered by the therapist to the parents is essential for the success of the intervention program.
\end{abstract}

Keywords: language delays, telepractice, therapeutic teem, speech and language theraphy

\section{Introducere}

Tamis-LeMonda, Bornstein și Baumwell (2001) au evidențiat faptul că în primii ani de viață dezvoltarea comunicării și a limbajului este strâns legată de dezvoltarea globală a copilului și de aspectele senzorio-motorii, cognitive și socio-afective. În această perioadă se elaborează semnale de comunicare, adesea foarte subtile (emiterea de vocale, surâsuri, priviri, expresii faciale, mișcări ale corpului). Valoarea comunicativă a acestor semnale este strâns determinată de contextul specific în care ele sunt emise, astfel permit mamei și copilului să „converseze” legat de ceea ce există între ei „aici și acum”.

Implicarea efectivă a părinților în dezvoltarea limbajului propriilor copii se poate realiza oferindu-le metodele practice de a-și descoperii copiii și potențialitățile de comunicare (Bodea Hațegan, 2016).
Printre atribuțiile specialistului în terapia tulburărilor de limbaj și comunicare se află și necesitatea de a dezvolta sau încuraja reapariția unor anumite comportamente sau de a favoriza apariția de atitudini care să faciliteze dezvoltarea comunicării. Acesta va dirija ca eforturile de comunicare ale copilului să fie repetate și încurajate de părinți.

Bornstein \& Baumwell (2001, apud. Roberts, M și Kaiser, A., 2011) consideră că părinții dețin un rol extrem de important în dezvoltarea limbajului propriilor copii. Ei sunt recunoscuți ca fiind primii dascăli ai copiilor, având o influență puternică în primii ani de viață. În opinia autorilor, patru aspecte ale interacțiunii părinte copil sunt asociate $\mathrm{cu}$ dezvoltarea limbajului la copil:

-timpul ( cantitativ) de interacțiune părinte - copil;

- receptivitatea (părintelui) la intenția de comunicare a copilului; 
- cantitatea și calitatea stimulilor lingvistici prezenți în această interacțiune;

- utilizarea de strategii de susținere a învățării limbajului

Variații în îndeplinirea acestor aspecte sunt asociate de autorii citați cu diferențe în dezvoltarea limbajului atât la copiii cu o dezvoltare tipică, cât și la copiii cu tulburări de limbaj și comunicare.

\section{Experiențta ïnternațională}

În decursul ultimilor ani au apărut studii și programe dezvoltate de centre de terapii care au abordat rolul părinților în terapia tulburărilor de limbaj și comunicare dintro nouă perspectivă.

Centre precum „The Hanen Centre” din Toronto sau "The Michael Palin Centre for Stammering Children" din Londra, au dezvoltat programe de interacțiune în triada terapeut - copil - părinte, considerând părinții ca parte din echipă.

S-a pornit de la intenția de a transforma rolul de simplu observator al părintelui într-o persoană care să facă parte din procesul de terapie al copilului. Această schimbare are la bază câteva principii practice:

-copiii învață să comunice în timpul activităților zilnice și a interacțiunii cu cele mai importante persoane din copilăria lor - părinții;

-părinții au mai multe oportunități de interacțiune în situații diverse, cotidiene decât le-ar putea crea terapeuții;

-părinții sunt cei care își cunosc cel mai bine copilul și sunt primii săi educatori.

Programele de terapie propuse de aceste centre sunt organizate astfel încât să îi învețe pe părinți să gestioneze situațiile de comunicare $\mathrm{cu}$ proprii copii în mediul familial. Astfel, părinții învață să folosească strategii de construire a limbajului copiilor în rutina cotidiană. Ceea ce au observat coordonatorii acestor programe este faptul că, la modul practic, terapia:

-face parte din programul zilnic al copilului;

-îmbunătățește comunicarea și interacțiunea dintre copil și părinte, nu doar dintre terapeut și copil;

-implică jocuri și activități zilnice care au loc în contexte familiale (în timpul călătoriei cu mașina, a plimbărilor, la culcare, la băiță) și devin ușor de integrat spre deosebire de spațiul nefamiliar al cabinetului;

este distractivă și motivantă pentru copil;

În cadrul activităților și a discuțiilor comune, grupuri mici de părinți învață să profite de oportunitățile cotidiene $\mathrm{cu}$ scopul de a îmbunătăți abilitățile de comunicare ale copiilor.

Programele „The Hanen Centre” organizează sesiuni de trening în grupe combinate la care participă părinții și specialiștii în TLC dar și sesiuni individuale de trening la care participă părinții alături de copil și specialistul TLC. Acest fapt oferă o experiență de învățare personalizată și adaptată fiecărei familii participante.

Pentru părinții ai căror copii manifestă dificultăți de comunicare, programele The Hanen Centre sunt organizate astfel încât să le formeze instrumentele necesare în ai ajuta pe copii să își atingă sau să își lărgească potențialul de comunicare. Astfel, au fost dezvoltate programe pentru 
părinți care vizează: Întârzieri de limbaj, Tulburare din Spectrul Autist și Sindrom Asperger.

Programele The Hanen Centre pentru părinți presupun participarea efectivă a părinților în sesiuni de grup, apoi se individualizează ședințele prin implicarea familiei în activitățile desfășurate în cadrul Centrului urmate de utilizarea telepracticii în continuarea activităților de terapie în mediul familial.

Telepractica este termenul utilizat în mod frecvent pentru serviciile de evaluare și intervenție oferite de un specialist în terapia tulburărilor de limbaj și comunicare prin intermediul tehnologiei (telefon, email sau videoconferință) (Lowry, 2020). Aceste sesiuni de terapie pot fi oferite live (în timp real) sau pot fi înregistrate astfel încât să fie urmărite atunci când timpul este favorabil copilului.

Lowry (2020) trasează o serie de avantaje ale participării familiilor la terapie prin intermediul telepracticii, astfel:

- accesibilitatea - face referire la diminuarea unor inconveniente de ordinul transportului, a distanței de deplasare, fenomene meteo nefavorabile deplasării, etc.

-flexibilitate - programul întâlnirilor dintre familie și terapeut poate fi mult mai ușor de modificat în funcție de nevoile care intervin pe parcurs;

- eficiența - prin reducerea timpului de deplasare a terapeutului sau a familiei, de organizare a mediului cabinetului și de eliberare a acestuia pentru începerea unei noi sesiuni;

- perspectiva asupra familiei - prin intermediul videoconferinței terapeutul poate să urmărească cu mai multă precizie modul în care copilul desfășoară activități în mediul familial, ceea ce poate să ofere posibilitatea dirijării îndeaproape a programului desfășurat.

Programul de telepractică desfășurat de The Hanen Centre vizează sprijinirea părinților în acțiunea de îmbunătățire a abilităților comunicaționale ale copiilor. Acest obiectiv se realizează prin desfasșurarea de întâlniri periodice cu familiile implicate (o dată pe săptămână timp de mai multe săptămâni) în cadrul cărora părinții primesc informații despre modul în care își pot ajuta copilul fiind îndrumați în acest demers și primind feedback permanent.

Specialiștii Centrului susțin faptul că învățarea limbajului de către copil se realizează în cea mai bună formă atunci când este lăsat să dirijeze conversația și se discută despre ceea ce-l interesează pe el mai mult. Programele propuse îi ajută pe părinți să își urmeze copilul în zona lui de interes astfel încât să îl mențină cât mai mult în interacțiune, oferindu-i stimuli și feedback-ul necesar să își construiască abilitățile de comunicare.

Datele înregistrate de organizatorii programelor de telepractică „The Hanen Centre" au arătat că, atât familiile cât și terapeuții participanți au raportat un nivel ridicat de satisfacție prin atingerea obiectivelor și reușita colaborării.

Programul de terapie coordonat de Centrul Michael Palin (Palin Centre) din Londra, se adresează copiilor cu vârste mai mari de 7 ani cu tulburări de ritm și fluență și organizează sesiuni de terapie prin 
modificarea modului de interacțiune dintre părinți și copil.

Palin Parent - Child Interaction (PCI) a fost dezvoltat în 1980 și se bazează pe încrederea acordată de terapeut și părinți profilului particular de pronunție al copilului, a punctelor tari și a vulnerabilităților prezente în vorbirea acestuia. Principiul de bază îl constituie faptul că părinții învață să interacționeze în permanență cu copiii în moduri care să le îmbunătățească abilitățile de comunicare, să sprijine fluența naturală și să crească timpii de interacțiune în mediul familial (Botterill \& Kelman, 2010).

Abordarea centrală este stabilirea unei relații de colaborare terapeutică în cadrul căreia sunt împărtășite cunoștințele și percepțiile terapeutului și ale părinților iar cei din urmă sunt încurajați să realizeze observații, să traseze propriile concluzii, să își fixeze scopurile în mod particular și să reflecteze asupra progreselor săptămânale. În cadrul acestei relații rolul terapeutul este de a facilita și a afirma, mai degrabă decât de a instrui, recomanda sau de a modela.

Părinții sunt încurajați să abordeze bâlbâiala în mod deschis, direct; sunt ajutați să își identifice fricile în legătură cu acest diagnostic. Prin definirea problemelor încă de la început, se poate reduce substanțial anxietatea familiei pe parcursul terapiei.

Botterill \& Kelman (2010) consideră ca prim scop al Palin PCI necesitatea de a forma o bază de cunoștințe, informații, abilități și încredere în managementul bâlbâielii ceea ce va sprijini terapia tulburărilor de ritm și fluență a copilului. Se are la bază ideea conform căreia părinții pot să influențeze abilitățile de comunicare ale copilului și încrederea în sine, iar aceasta, mai ales în cazul copiilor cu vârste mici, este un pivot pentru procesul de schimbare.

În timpul sesiunilor Palin PCI, părinții vizionează înregistrările făcute în timp ce se jucau cu copiii în cadrul clinicii. Conduși prin procesul de înțelegerea a nevoilor propriului copil, părinții primesc ghidaj în cadrul unui proces de identificare și de creștere a acelor interacțiuni și strategii de comunicare favorabile îmbunătățirii fluenței copilului.

\section{Directiii de cercetare}

Pornind de la datele analizate în literatura de specialitate, au fost trasate următoarele direcții de cercetare:

\section{Obiectĩve}

Realizarea unui program de terapie a tulburărilor de limbaj și comunicare prin colaborarea dintre terapeut și părinți;

Proiectarea activităților de sprijin în cadrul cărora părinții primesc informații despre modul în care își pot ajuta copilul, fiind îndrumați în acest demers și primind feedback permanent;

Instrumentarea părinților cu strategii practice care să sprijine dezvoltarea limbajului funcțional al copilului în mod natural, în contextul cotidian al vieții de familie;

\section{Ipoteze}

Implicarea părinților în implementarea de strategii de intervenție specifice terapiei limbajului și a comunicării favorizează dezvoltarea abilităților verbale ale copilului; 
Organizarea ședințelor de terapie logopedică cu implicare parentală conduce la creșterea calității interacțiunii copil - părinți.

\section{Participantị}

La acest program de intervenție logopedică au participat 7 copii, 5 băieți și 2 fete, cu vârste cuprinse între 4-6 ani, diagnosticul logopedic stabilit ca urmare a evaluării complexe fiind de întârziere în dezvoltarea limbajului, dislalie polimorfă.

\section{Instrumente}

Inventarul de evaluare a limbajului expresiv/receptiv (pentru părinți) aplicat în etapele de pretestare și postestere

Diagnosticul tulburării de limbaj

- Proba de evaluare a nivelului de dezvoltare a limbajului(Stanica și Vrașmaș, 1997), Albumul logopedic, soft educaţional Logopedix

Diagnosticarea nivelului de cunoștințe și de performanță

- Baza materială din cadrul cabinetului: materiale intuitive, jocuri de asociere, etc.

Figura 1. Exemple de activități propuse în cadrul programului de terapie

\begin{tabular}{|c|c|c|c|}
\hline Tema & $\begin{array}{l}\text { Indicații pentru etapa } \\
\text { terapeutică }\end{array}$ & Recomandări & Observații \\
\hline $\begin{array}{l}\text { Construirea unor } \\
\text { interacțiuni pozitive } \\
\text { prin intermediul } \\
\text { jocului. }\end{array}$ & $\begin{array}{l}\text { Se iniţiază jocuri simple } \\
\text { cu ajutorul unor } \\
\text { figurine, mascote, care } \\
\text { să sprijine stabilirea } \\
\text { unei relaţii de } \\
\text { comunicare, a unei stări } \\
\text { de bine a copilului. }\end{array}$ & $\begin{array}{l}\text { Lăsaţi copilul să dirijeze } \\
\text { jocul. }\end{array}$ & $\begin{array}{l}\text { Se încurajează dorința } \\
\text { copilului de a se juca. Se } \\
\text { formează jocul copilului } \\
\text { (trecerea de la } \\
\text { manipularea efectivă a } \\
\text { jucăriei, la crearea unui } \\
\text { scenariu de joc). }\end{array}$ \\
\hline $\begin{array}{l}\text { Formarea şi dezvoltarea } \\
\text { abilităţilor de } \\
\text { discriminare, } \\
\text { identificare şi } \\
\text { interpretare a stimulilor } \\
\text { externi care apar în } \\
\text { mediul ambiant. }\end{array}$ & $\begin{array}{l}\text { Activităţi de percepţie şi } \\
\text { diferenţiere a } \\
\text { zgomotelor, sunetelor, } \\
\text { vocilor. } \\
\text { Exerciţii - joc pentru } \\
\text { dezvoltarea unor forme } \\
\text { ale atenţiei (auditivă, }\end{array}$ & $\begin{array}{l}\text { Atrageți atenția } \\
\text { copilului asupra } \\
\text { zgomotelor / sunetelor } \\
\text { din mediul ambiant, } \\
\text { îndreptați privirea spre } \\
\text { direcţia din care se aude }\end{array}$ & $\begin{array}{l}\text { Se încearcă } \\
\text { sensibilizarea atenţiei } \\
\text { copilului prin exerciţii } \\
\text { de identificare şi reacţie } \\
\text { la modificările care apar } \\
\text { în mediul ambiant. }\end{array}$ \\
\hline
\end{tabular}

Diagnosticul relației familie-copil

- Interviul cu părinţii

Au fost parcurse etape de :

-stimulare verbal-auditivă şi cognitivă;

- de întărire a abilităţilor de exprimare verbal-orală;

- dezvoltare a abilității de înțelegere a mesajului oral;

-părinţii au primit explicaţii ale exerciţiilor şi rolului lor în terapie precum şi răspunsurile care erau aşteptate din partea copilului;

- sumarizare a exerciţiilor parcurse şi a performanţelor înregistrate de copil, a obiectivelor urmărite, precum și a dificultăților întâmpinate;

-întocmire a listei de cuvinte din vocabularul de bază care să sprijine achiziția limbajului funcțional (diferit de la un copil la altul, în funcţie de stilul familial, de preferințele copilului, etc.)

- *se urmărește să folosească cuvinte şi propoziţii care îi sunt utile în viaţa de zi $\mathrm{cu}$ zi. 
vizuală, tactil-

kinestezică). zgomotul şi acordați

semnificant verbal.
Se încurajează formarea / menţinerea unui canal de comunicare deschis părinte-copil.

Figura 2. Exemple de sugestii pentru părinți

\begin{tabular}{ll}
\hline \hline Răspundeți prompt & $\begin{array}{l}\text { Este important ca să fiți atenți la intenția de comunicare a copilului și să răspundeți la } \\
\text { ceea ce face sau spune acesta }\end{array}$ \\
\hline Cuvinte noi & $\begin{array}{l}\text { Cuvintele sunt ușor de reținut atunci când sunt legate de context. Repetați cuvintele nou } \\
\text { apărute și asociați-le cu obiecte sau evenimente prezente }\end{array}$ \\
\hline Primele propoziții & $\begin{array}{l}\text { Orice încercare a copilului de a lega două sau mai multe cuvinte trebuie încurajată și } \\
\text { întărită. Repetați propoziția alcătuită de copil, chiar dacă nu este completă, oferind } \\
\text { varianta corectă într-un mod pozitiv }\end{array}$ \\
\hline $\begin{array}{l}\text { Povestea de „noapte } \\
\text { bună” }\end{array}$ & $\begin{array}{l}\text { Adaptați povestea citită, scurtați frazele complexe, ușurați limbajul astfel încât să îl } \\
\text { mențineți pe copil atent cât mai mult timp. Folosiți și alte cuvinte, mai ușor de perceput } \\
\text { de copil }\end{array}$ \\
\hline La cumpărături & $\begin{array}{l}\text { Folosiții acest prilej pentru a forma cuvinte noi. Întocmiți o mini listă de cumpărături pe } \\
\text { care să o urmăriți alături de copil. Acesta este un prilej bun de a-i explica faptul că poate } \\
\text { să cumpere doar ce este pe listă }\end{array}$ \\
\hline \hline
\end{tabular}

\section{Rezultate obținute}

Am ales ca metodă de cercetare, metoda studiului de caz pentru a urmări evoluția calitativă a aspectelor care țin de dezvoltarea individuală a participanților la programul de terapie. Din acest punct de vedere sumarizez câteva rezultate obținute în acest demers.

Analizând Diagrama 3, care ilustrează răspunsurile părinților la Inventarul de evaluare a limbajului expresiv/receptiv, în cele două etape de pretestare respectiv postestare, putem observa o îmbunătățire considerabilă a percepției părinților asupra evoluției limbajului expresiv și receptiv al copilului.

Astfel, un progres remarcabil se evidențiază în cotarea abilității copilului de a cere în mod explicit mâncare (itemul 1) care a fost evaluat ca manifestându-se foarte $\operatorname{rar}(2)$ în etapa de pretestare, spre deosebire de etapa de postestare, când apare în chestionar evaluat $\mathrm{cu} 5$ echivalentul pentru de cele mai multe ori.

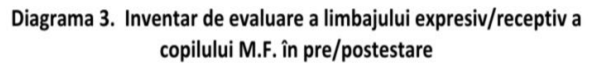
copilului M.F. în pre/postestare

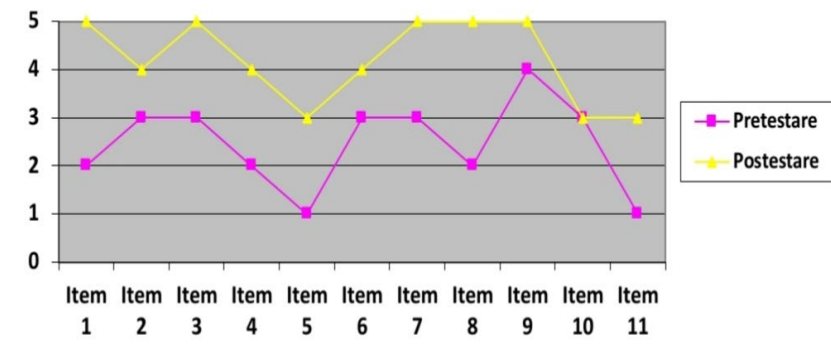

Un prim aspect urmărit a fost evoluția limbajului expresiv.Această arie a fost evaluată cu ajutorul itemului 3 care vizează utilizarea de cuvinte și expresii cu scopul de a denumi obiecte, persoane, acțiuni și a fost marcat de părinți ca fiind prezent într-o mai mare măsură decât în etapa inițială de pretestare, fiind cotat cu valoarea $5^{-}$corespunzătoare utilizării frecvente a limbajului verbal ca modalitate de interacțiune și comunicare. 
A doua dimensiune urmărită în cadrul Inventarului adresat părinților a fost cea a evoluției limbajului receptiv și a fost evaluat cu ajutorul itemului 8, care investighează percepția părinților în ceea ce privește abilitatea copilului de a înțelege și răspunde la întrebări simple. La acest item, părinții au bifat în pretestare indicele 2- corespunzător criteriului foarte rar, iar în etapa finală, în postestare indicele 5 - de cele mai multe ori.

Se remarcă din partea copilului o mai bună capacitate de exprimare verbală și un nivel mai bun al inteligibilității vorbirii sale resimțită de părinți. Însă, putem interpreta rezultatul obținut și prin faptul că implicarea directă a părinților în dezvoltarea abilităților de limbaj și comunicare ale propriului copil, are efecte benefice asupra stabilirii unui limbaj comun precum și o interacțiune mai bună prin creșterea timpului petrecut împreună.

La evaluarea realizată la patru luni de la demararea intervenției logopedice au fost sintetizate rezultate precum :

-s-a îmbunătăţit contactul vizual. Copilul direcţionează şi fixează privirea spre sarcina de lucra sau spre fața logopedului;

-sunt pronunţate toate vocalele cu apertura bucală specifică, iar nazalizarea este corectată în totalitate;

-sunt pronunţate consoanele ocluzive labiale şi dentale; se reuşeşte plasarea acestora în silabe directe şi inverse precum şi în cuvinte mono şi bisilabice în combinații intervocalice;

-s-a reuşit integrarea în mediul instituțional al grădiniței, crizele de ataşament fiind depăşite în mare măsură;

-sunt în curs de formare abilităţile de exprimare a propoziţilor cu rol de informare, cerere sau răspuns; de asemenea se antrenează formarea noţiunilor care exprimă spaţialitatea, temporalitatea, mărimea, distanța.

\section{Concluzii}

Participarea părinților în programul de terapie a tulburărilor de limbaj și comunicare a propriului copil prin colaborare terapeutică a contribuit la schimbarea percepției față de tulburarea de limbaj a copilului, a îmbunătățit interacțiunea cu acesta, devenind mai cooperanți și mai puțin critici.

Acest program de colaborare terapeutică dintre logoped, copil și părinți, a permis valorificarea observațiilor pe care părinții le realizează în mediul natural al copilului, în viața cotidiană, completând datele obținute în procesul de evaluare complexă a copilului și implicit propunerea unui program de intervenție personalizat nevoilor copilului.

Numărul redus de participanți implicați în prezenta cercetare, caracteristicile limbajului, vârsta acestora precum și buna implicarea a părinților în programul terapeutic, au condus la obținerea unor rezultate favorabile confirmării obiectivelor și a ipotezelor proiectate pentru acest studiu.

Tema abordată în această lucrare de cercetare poate fi valorificată în contextul actual al desfășurării în format telepractică a terapiei tulburării de limbaj și comunicare, având ca sugestie de continuare a cercetării extinderea eșantionului de participanți la studiu și 
realizarea unor ghiduri practice adresate părinților.

\section{Bibliografie}

Bodea Hațegan, C. (2016). Logopedia. Terapia tulburărilor de limbaj. Structuri Deschise, București: Editura Trei.

Botterill, W., Kelman, E. (2010). Palin Parent - Child Interaction. Chapter 5, in Treatment of Stuttering: Established and Emerging Interventions.

Lowry, L. (2020). Moving Hanen Parent Programs Online. Hanen Centre.

Roberts, M, Kaiser, A. (2011). The Effectiveness of Parent-Implemented Language Interventions: A MetaAnalysis, in American Journal of Speech-Language Pathology 20(3):18099

Tamis-LeMonda, $\quad$ C., $\quad$ Bornstein,M., Baumwell, L.(2001). Maternal Responsiveness and Children's Achievement of Language Milestones, Journal Child Development, May/June Volume 72, Number 3, Pages 748-767; http://www.hanen.org/Helpful-

Info/Articles/Moving-Hanen-Parent-

Programs-Online.aspx

http://downloads.lww.com/wolterskluwe r_vitalstream_com/samplecontent/9780781771047_Guitar/sample s/Chaptero5.pdf.

'.Prof. Logoped, Școala Profesională Specială.Câmpulung Moldovenesc, Suceava.

E-mail: $\underline{\text { luciabtz84@gmail.com }}$ 


\title{
Autism, schizofrenie, ADHD. Perspective convergente
}

\section{Bogdana MICLEA ${ }^{1}$}

\begin{abstract}
Over time, continuous efforts have been made to clarify and circumscribe diagnoses of autism, schizophrenia, and attention deficit hyperactivity disorder (ADHD). The diagnostic split between the 3 disorders dominated psychiatry after the 80 s, being still used and recognized as such by the diagnostic manuals. Recently a shift and flexibility of the psychiatric paradigm has been noticed. The categorical perspective on mental illness is gradually complemented by the dimensional one. In the last decade, research in the field of neuroscience and psychology has brought evidence in favor of a partial overlap between ADHD, autism and schizophrenia. The hypothesis of a partial overlap can also be supported by non-medical or psychological theorizations, related to common deficits of symbolic structuring of the psyche in achieving a coherent representation of the world and of one's own person.
\end{abstract}

Keywords: autism, schizophrenia, ADHD, diagnosis, partial overlap

Sistemele de clasificare elaborate de Organizația Mondială a Sănătății (OMS) și Asociația Psihiatrică Americană (APA) au recurs la o modalitate de clasificare predominant epidemiologică, ceea ce a modelat înțelegerea bolilor psihice pe criterii mai degrabă statistice și descriptive după anii 19501. Autismul, schizofrenia și tulburarea de hiperactivitate cu deficit atențional (ADHD), sunt considerate în prezent categorii diagnostice distincte, ceea ce implică tratament farmacologic și psihologic specific însă de-a lungul timpului, s-au făcut eforturi continue de a clarifica și circumscrie cele 3 diagnostice.

\section{Autismu!}

Autismul considerat acum o tulburare de neurodezvoltare, a fost înțeles inițial ca o formă de psihoză infantilă, însuși termenul "autistic" fiind preluat de la Bleuler (1911) care îl utiliza pentru a descrie manifestări ale schizofreniei. Mai târziu, psihologii și psihiatrii europeni - în mod particular cei britanici și cei americani au revizuit conceptul inițial de psihoză infantilă și au clasificat autismul ca distinct de schizofrenie asociindu-l $\mathrm{cu}$ întârzierea mintală și alte anomalii de dezvoltare psihică a copiilor. Ulterior a fost considerat o tulburare de comunicare. În 1980 autismul a fost inclus separat în DSM III, în randul tulburărilor pervazive de dezvoltare ale copilăriei și totodată s-au eliminat simptomele autiste din descrierea schizofreniei adultului (prezente în DSM II)2. Pentru încadrarea diagnostică s-a recurs la criterii descriptive behavioriste și ulterior cognitiviste, au persistat însă dificultățile de conturare a unui tablou psiho-patologic stabil și de identificare a unor cauze specifice. Aceste variații în prezentarea clinică în care există totuși un set central de alterări, stabil de-a lungul vieții, a condus la lărgirea fenotipului autist (McPartland, J., \& Volkmar, F. R. 2012). Din aceste motive în DSM V s-a adoptat denumirea de Tulburare de Spectru Autist (TSA) care cuprinde tablouri clinice variate având ca elemente comune: disfuncția socială, comunicarea deviantă, comportamentele neobișnuite sau bizare, etiologia fiind una neurocognitivă. 


\section{Schizofrenia}

Schizofrenia (SCZ) rămâne o afecțiune incomplet cunoscută, considerată a avea o etiologie mixtă genetică și psiho-socială, care destructurează persoana și îi afectează extensiv funcționarea. Schizofrenia copilului este o tulburare rar raporatată prepubertar (sub 1/10 ooo copii) iar în numeroase cazuri a fost observată comorbidatea cu tulburări de neurodezvoltare cum ar fi dizabilitatea intelectuală sau autismul. În adolescență și la adulții tineri incidența schizofreniei crește semnificativ ( $1 / 500$ tineri de 18 ani). În majoritatea cazurilor nu s-au identificat elemente clare în copilărie prin care s-ar putea anticipa debutul ulterior al psihozei însă s-a delimitat o categorie de copii și tineri cu risc foarte înalt de a dezvolta schizofrenie. Aceștia prezintă o asociere de factori: personalitate schizotipală, antecedente familiale de schizofrenie, simptome psihotice tranzitorii, subclinice și declin funcțional. Identificarea acestor persoane cu risc ridicat de boală și intervenția terapeutică precoce este esențială în vederea reducerii riscului debutului psihozei clinice (IACAPA). Similar autismului, heterogenitatea tabloului clinic a impus lărgirea conceptului iar în prezent vorbim de tulburări din spectrul schizofreniei.

\section{ADHD}

Manifestări similare celor incluse actual în tulburarea de hiperactivitate cu deficit atențional au fost descrise deja din 1798 de Crichton totuși conceptul modern al acestei afecțiuni este de dată relativ recentă. Tulburarea de hiperactivitate cu deficit atențional - ADHD - este considerată în prezent o afecțiune cu o componenentă ereditară importantă $\begin{array}{lcr}\text { caracterizată } & \text { prîntr-o } & \text { disfuncție } \\ \text { neuropsihologică } & \text { a } & \text { inhibiției } \\ \text { comportamentale } & - & \text { componentă }\end{array}$ funcțiilor executive implicând și memoria de lucru5. Denumirea de ADHD a fost recent introdusă în ICD 11. ICD 10 includea o categorie diagnostică similară numită tulburare hiperkinetica - HKD - cu o subcategorie în care era menționată afectarea concomitentă a atentiei. DSM IV-TR adoptase deja aceasta formulare de ADHD. Până relativ recent, autismul și ADHD erau menționate în secțiuni de psiho-patologie aflate la distanță - deși s-a observat că un procent ridicat de copii prezintă simptome din ambele afecțiuni devreme în dezvoltare - însă în DSM V și ICD 11 cele două sunt incluse în cadrul Tulburărilor de neurodezvoltare sugerându-se existența unor deficite centrale similare și a unui continuum între ADHD și autism.

Se remarcă faptul că în timp, conceptualizarea celor 3 afecțiuni s-a modificat iar separarea clară între autism, schizofrenie și ADHD precum și necesitatea încadrării manifestărilor de tip hiperactivitate și neatenție într-o categorie diagnostică suplimentară - în cazul copiilor cu autism - nu este întotdeauna ușor de justificat. Pentru psihiatrii care iau pentru prima dată în evidență un pacient adult este adesea dificil să facă din punct de vedere clinic o diferență clară între autism și schizofrenie sau o tulburare de personalitate schizotipala iar în mediul clinic al practicii cotidiene s-a menținut observația că autismul "evoluează într-o manieră asemănătoare schizofreniei” (Dobreascu, 2016) . 
Scindarea diagnostică menționată a dominat psihiatria de după anii 8o, fiind încă utilizată și recunoscută ca atare de manualele de diagnostic OMS și APA. Recent se observă o nuanțare și flexibilizare a paradigmei psihiatrice, care anunță o posibilă schimbare. Perspectiva categorială asupra maladiilor psihice menținută datorită nevoii de omogenitate, precizie și claritate în cercetare și clinică este treptat completată cu cea dimensională care admite necesitatea recunoașterii unei suprapuneri parțiale între patologii și între boală și normalitate. În plus maladiile sunt abordate de noile manuale de diagnostic în perspectivă developmentală, adică grupate corelat cu poziția lor în cursul dezvoltării unei persoane, având implicații în evoluția globală a unui individ în plan psihic. Pe această linie de conceptualizare, tulburările din spectrul schizofreniei sunt descrise imediat după cele de neurodezvoltare. Între aceste "spectre" ale autismului și schizofreniei distanța s-a redus iar ADHD este și el regăsit mai apropiat de TSA, în aceeasi grupă de tulburări de neurodezvoltare și nu mai este descris alături de tulburările de comportament (APA, 2013) .

La această reorientare a paradigmei stiințifice privind patologia psihică, au contribuit în ultima decadă cercetări din domeniul neuroștiințelor și a psihologiei. Acestea au adus evidențe în favoarea unei parțiale suprapuneri între ADHD, autism și schizofrenie iar alte afecțiuni ca tulburarea afectivă bipolară, dizabilitatea intelectuală și depresia sunt și ele vizate de cercetători.

Un studiu genetic recent (Olafur O Gudmundson, 2019) indică faptul că
ADHD, autismul și schizofrenia impărtășesc aceleași alele CNV (copy number variations - variațiile numărului de copii, adică pentru același locus perechile de baze care alcătuiesc materialul genetic au aceeași structură repetiții sau deleții).

Un alt studiu din 2017 care a inclus peste 33 ooo de cazuri și aproape 28 ooo de persoane în grupul de control arată că există un grad semnificativ de suprapunere genetică între ADHD, autism, schizofrenie, dizabilitate intelectuală, tulburare afectivă bipolară, tulburare depresivă majoră și tulburare de personalitate antisocială (Huiying Zhao, 2017) la nivelul SNP (single nucleotide polymorphism - substituție a unei singure nucletotide într-o poziție specifică a genomului ceea ce duce la existența mai multor alele)

Multe alte studii GWAS (genome-wide association studies) din ultima decadă prin care se cercetează pe cohorte populaționale mari variațiile genetice care ar putea fi asociate cu diverse maladii au subliniat suprapunerea genetică semnificativa între schizofrenie și autism sau între ADHD și autism atât la copii cât și la adulțio(Demontis 2019). S-a propus existența unei constelații poligenice care conduce prin efectul cumulat al SNP, detectată prin analiză GWAS, la risc înalt pentru unele afecțiuni cum ar fi ADHD sau la alte fenotipuri patologice dintre cele menționaten(Middeldorp, 2016). Această perspectivă e în concordanță cu abordarea dimensională a maladiilor psihice în care implicarea variată cantitativ a anumitor caracteristici conturează un profil sau altul de boală și îl face să devină evident clinic, depășind normalitatea 


\section{Conștiințta de sine}

Conștiința de sine este un element cheie al oricărei experiențe conștiente și a reglării comportamentului. Constiința de sine presupune $\mathrm{o}$ autoreferențialitate care însoțeste orice eveniment desfășurat în stare de veghe (trezire fenomenologică). Conștiința anoetică este prezentă înainte de dezvoltarea limbajului și presupune un flux perceptiv-afectiv fundamental care se traduce prin impresia că ceva este trăit la persoana I. Gradual se dezvoltă constiința noetică bazată pe cunoaștere și concepte. Aceasta va evolua și se va remania apoi în cursul vieții încorporând o gamă tot mai variată de experiențe implicând invațare dar și amintire și recunoaștere și asigurând astfel o înțelegere coerentă și structurată a lumii, nefracturată de localizarea în timp sau context și permițând proiecția în viitor - constiința autonoetică. Rețele neuronale subcorticale sunt implicate în conștiința anoetică. De buna lor funcționare va depinde dezvoltarea ulterioară a constiinței noetice ce permite învățarea făcând apel la memoria semantică (susținută de structuri cerebrale intermediare cum ar fi ganglionii bazali și zone din cortexul prefrontal și temporal) și autonoetice ce face apel și la memoria episodică și care implică rețele neocorticale de ordin superior. În copilărie, în perioada prelingvistică a existenței umane, lumea este recepționată fără referințe conceptuale, cu o implicare afectiv-corporală predominantă. Ulterior în cursul experiențelor cotidiene ce presupun conștiința noetică și autonoetică explicită va fi implicată și constiința anoetică corelată $\mathrm{cu}$ dimensiunea corporal-afectivă, implicită a fenomenelor. Pe lângă rețelele corticale sunt activate și cele subcorticale iar un proces de sincronizare/desincronizare între procese de activare neuronală de la niveluri diferite se desfășoară în cursul experienței conștiente. $\mathrm{O}$ rețea paralimbică este activă în menținerea conștiinței de sine iar regiunile acestei rețele interacționează prin gama sincronie reglată de dopamină și alți neurotransmițători prin interneuronii de tip GABA. S-a constatat că atât în autism cât și în ADHD și schizofrenie există alterări majore ale funcționării acestei rețeleıı (Hans C Lou, Vandekerckhove 2014)

\section{Cogniția socială.}

Felul în care ne raportăm la ceilalți (teoria minții-ToM) este modificată în autism, schizofrenie și ADHDı3. Mentalizarea este considerată din punct de vedere psihologic o abilitate esențială cogniției și interacțiunii sociale. Adică modul în care vom interacționa cu ceilalți și ne vom raporta la ei este strâns legat de felul în care percepem și interpretăm gesturile, mimica, comportamentul și ceea ce spun ceilalți. În toate cele 3 afecțiuni s-a constatat că există o afectare a cogniției sociale deși sunt descrise caracteristici particulare fiecărei afecțiuni. În schizofrenia cu tablou paranoid studii de rezonanță magnetică funcțională (fMRI) au evidențiat faptul că pacienții prezintă hiperintenționalitate, adică activare a creierului în unele zone atunci când li se prezintă informații care cer mentalizare (atribuire excesivă de intenții în interacțiunea sociala și o dificultate de a discrimina între propriile intenții și reprezentări ale statusului mintal și cele ale altora). Autismul se caracterizează prin hipointenționalitate - Indivizii cu TSA 
prezintă o imposibilitate de "citire a gândurilor" celorlalți, adică au dificultăți în înțelegerea intențiilor celor cu care interacționează, raportându-se la ei mai degrabă obiectual. Hipointenționalitatea din TSA este asociată cu hipoactivare în zone ale creierului care în mod obișnuit sunt corelate $\mathrm{cu}$ interacțiunea socială complexă (Ciaramidaro A, 2015). Zonele din creier unde se produce hiper/hipoactivare în SCZ/TSA detectate prin fMRI sunt: Cortexul prefrontal medial (implicat în interacțiunea socială complexă), sanțul drept postero-superior medial temporal, joncțiunea adiacentă temporo-parietală (cele 2 arii fiind implicate mai ales în sarcini cognitive mai simple ca : "citirea” intențiilor cuiva).

Un alt studiu care cuprinde un review al literaturii, efectuat în 2018 susține în mod similar diferența de intenționalitate între autism și schizofrenie care coexistă însă cu dificultăți similare în ceea ce priveste ToM de ordinul 1 și 2, procesarea emoțiilor și percepția socială - deși cantitativ mai marcate în autism față de schizofrenie (E Le Gall, 2018)

Studii ale biomarkerilor prin care s-a încercat identificarea unui pattern funcțional sau anatomic ce ar putea ajuta la discriminarea între ADHD și autism la copii au relevat faptul că între cele două afecțiuni există o suprapunere parțială semnificativă care contrazice separarea categoriala netă, susținută până în prezent16 (Kernbach, 2018)

În ADHD se constată existența unui deficit al funcțiilor executive ceea ce duce la o afectare a teoriei minții iar studii din ultimii 30 de ani au descris dificultățile celor cu aceasta afecțiune de a empatiza cu altii, de a recunoaște emoțiile pe față sau nuanțele prozodice în vorbire (Wilmar Pineda-Alhucema, 2018, Uekermann J, Kraemer, 2010)

În mod tradițional, medicina și psihologia îl gândesc pe celălalt ca un obiect exterior, îl cerceteaza și îl descrie, confirmând experimental ipotezele de lucru. Din perspectivă umanistă încercarea de înțelegere a realității este un demers care pornește de la început din alta poziție gândirea și percepția celuilalt este posibilă ca obiect separat doar parțial, cel care studiază și obiectul său de studiu fiind parte integrantă a aceleași realități. Întrebări de genul: Cine sunt eu? Ce face diferența dintre mine și tot ce e în jurul meu? Cum îl percep și gîndesc pe celălalt, pe mine insumi, lumea în general? - sunt esențiale în configurarea sinelui (identitatea, subiectivitatea) și a celorlalți (alteritatea) și pot fi corelate cu capacitatea de simbolizare. Simbolul reflectă eterna căutare a ceva ce se dorește a fi obiectivat fără să se reușească complet însă niciodată. Simbolizarea ne permite, prin implicarea ei în elaborarea conceptelor, sa avem referințe comune la un moment dat și intr-un context dat și permite deci, înțelegerea intențiilor celoralți făcând apel la un limbaj comun. E inclusă aici nu doar vorbirea ci și celelalte limbaje: mimico-gestual, al privirii cu sens, al tonalitații vocii și cel grafic, care asigură comunicarea și integrarea socială adecvată „practica socială este o practică simbolică” (Vintilă Mihăilescu, 5 introduceri în antropologie). Simbolizarea favorizează, în raporturile cu ceilalți, atribuirea în mod flexibil și adecvat de sensuri multiple și variate unor obiecte, situații, comportamente și cuvinte. Simbolizarea ne permite sa avem o unitate 
internă ce se păstrează în pofida diversității contextuale și chiar fiziologice cu care ne confruntăm de-a lungul vieții. Mijlocit de simbolizare, putem să fim întro relație interumană de reciprocitate firească și implicită (tacită în mare parte). Prin simbolizare, omul este capabil să fie în același timp în și în afara unui eveniment perceput (extern) sau intern și se produce un permanent dute-vino între ceea ce rămâne neconștientizat și ceea ce apare în câmpul conștiințeizo. Există o interacțiune reciprocă și o fluctuație între ceea ce e implicit și ceea ce e declarat, această interșanjabilitate, ca o oscilatie permanentă asigurată de funcția simbolizării, dă un sens lumii. Prin acest proces activ, de simbolizare, care se desfășoară între ceea ce resimțim că trăire interioară și tot ce constituie lumea exterioară este favorizată ordonarea și structurarea pshicului uman și totodată intuiția unei ordini externe.

Procesul decurge firesc în cazul majorității și nu ridică probleme deosebite decât punctual și tranzitoriu. El este însă alterat în cazul autismului, psihozei și tulburării de hiperactivitate cu deficit atențional, în care consecutiv deficitului simbolic, identitatea/alteritatea este afectată. Ceilalți sunt mai degrabă obiecte ce pot fi înțelese metodic, algoritmic, „inginerește” eventual ca un ansamblu sistematic mai mult sau mai puțin complex. În psihoza paranoidă spre exemplu sistemul e aberant deoarece e fix și îngust construit, după o logică internă ce nu permite contraargumentare iar delirul și producțiile halucinatorii functionează că ancore existențiale ce impiedică deriva generalizată. Autismul ne apare, din această perspectivă, ca o prea mare fixare în obiectual, ca o lipsă a acestei capacități de pendulare, mediată simbolic, între potență și concretizare. Obiectul rămâne același (nu sunt evocate implicit toate posibilele sensuri) indiferent de contextul spațio-temporal, celălalt nu este intuit ca un altul aflat între, se depun eforturi pentru stabilirea unei coerențe (de unde repetiția, stereotipia) și apare spaima în fața unui obiect inclasabil și care nu poate fi integrat în mod firesc intr-un sistem aflat în continuă remaniere. Deficitul de simbolizare duce la o dispersie în fragmentar, imediat, suprafață, cu aparența agitației motorii și a deficitului atențional, în lipsa coerenței asigurată de matricea invizibilă care le subîntinde. În consecință, autistul observă diversitatea dar interpretează diferența mai degraba metodic, făcând apel la logică și rezultând o interpretare rigidă, nepermeabilă la ceea ce nu poate fi gândit ci doar intuit. El se bazează în înțelegerea realității pe experiențele senzoriale asociate formal cu denumirile date obiectelor de către ceilalți și nu realizează (sau realizează deficitar, incomplet, parțial) integrarea celor două componente. Capacitatea redusă de simbolizare antrenează alterări ale raportului cu realitatea externă și internă, cu ceilați și cu sine insuși, cu consecințe în plan clinic și implicații numeroase în viața cotidiană.

După anii 50 cercetarea în psihiatria și psihologia copilului a virat spre o abordare empirică, statistică, inductivă (evidence based medicine) în defavoarea metodelor anterioare, considerate speculative. Tot mai multe studii biologice recente, aduc dovezi că ADHD, autismul și schizofrenia nu sunt entități complet distincte ci mai degrabă tulburări înrudite. Cercetările de 
cogniție socială admit medierea simbolică a cogniției și comunicării (, Ricks DM, Wing L 1975,-Ponty M, 2017) Ipoteza unei parțiale suprapuneri poate fi susținuta și prin teoretizări non-medicale sau psihologice, legate de deficite comune de structurare simbolică a psihicului în realizarea unei reprezentări coerente a lumii și a propriei persoane. Identificarea unei convergențe între cele 3 fenotipuri clinice antrenează necesitatea unor ajustări de paradigmă diagnostică și terapeutică iar cercetări ulterioare ne vor aduce clarificări suplimentare în privința acestei perspective ce se conturează în domeniul sănătății mintale și care reactualizează modalități anterioare de înțelegere a patologiei psihice.

\section{Bibliografie:}

1. American Psychiatric Association. (2013). Diagnostic and statistical manual of mental disorders (5th ed.). Washington, DC.

Ciaramidaro A, Bölte S, Schlitt S, Hainz D, Poustka F, Weber B, Bara BG, Freitag C, Walter H. Schizophrenia and autism as contrasting minds: neural evidence for the hypo-hyper-intentionality hypothesis. Schizophr Bull. 2015 Jan;41(1):171-9. doi: 10.1093/schbul/sbu124. Epub 2014 Sep 9. PMID: 25210055; PMCID: $\mathrm{PMC}_{4266299 .}$

Demontis, D., Walters, R. K., Martin, J., Mattheisen, M., Als, T. D., Agerbo, E., Baldursson, G., Belliveau, R., BybjergGrauholm, J., Bækvad-Hansen, M., Cerrato, F., Chambert, K., Churchhouse, C., Dumont, A., Eriksson, N., Gandal, M., Goldstein, J. I., Grasby, K. L., Grove, J.,
Gudmundsson, O. O., ... Neale, B. M. (2019). Discovery of the first genomewide significant risk loci for attention deficit/hyperactivity disorder. Nature genetics, $51(1)$, 63-75. https://doi.org/10.1038/s41588-0180269-7

\section{DSM History (psychiatry.org)}

Evans B. (2013). How autism became autism: The radical transformation of a central concept of child development în Britain. History of the human sciences, 26(3), 3-31. https://doi.org/10.1177/09526951134843 $\underline{20}$

Gudmundsson OO, Walters GB, Ingason A, Johansson S, Zayats T, Athanasiu L, Sonderby IE, Gustafsson O, Nawaz MS, Jonsson GF, Jonsson L, Knappskog PM, Ingvarsdottir E, Davidsdottir K, Djurovic S, Knudsen GPS, Askeland RB, Haraldsdottir GS, Baldursson G, Magnusson P, Sigurdsson E, Gudbjartsson DF, Stefansson H, Andreassen OA, Haavik J, ReichbornKjennerud T, Stefansson K. Attentiondeficit hyperactivity disorder shares copy number variant risk with schizophrenia and autism spectrum disorder. Transl Psychiatry. 2019 Oct 17;9(1):258. doi: 10.1038/s41398-0190599-y. PMID: 31624239; PMCID: PMC6797719.

IACAPAP

H.5-SCHIZOPHRENIA072012.pdf (iacapap.org)

Kernbach JM, Satterthwaite TD, Bassett DS, Smallwood J, Margulies D, Krall S, Shaw P, Varoquaux G, Thirion B, Konrad K, Bzdok D. Shared endophenotypes of default mode dsfunction în attention deficit/hyperactivity 
disorder and autism spectrum disorder. Transl Psychiatry. 2018 Jul 17;8(1):133. doi: 10.1038/s41398-018o179-6. PMID: 30018328; PMCID: PMC6050263.

Le Gall E, Iakimova G. Cognition sociale dans la schizophrénie et les troubles du spectre de l'autisme: points de convergences et différences fonctionnelles [Social cognition în schizophrenia and autism spectrum disorder: Points of convergence and functional differences]. Encephale. 2018 Dec;44(6):523-537. French. doi: 10.1016/j.encep.2018.03.004. Epub 2018 Aug 16. PMID: 30122298.

Lou HC. Paradigm shift în consciousness research: the child's self-awareness and abnormalities în autism, ADHD and schizophrenia. Acta Paediatr. 2012 Feb;101(2):112-9. doi: 10.1111/j.16512227.2011.02456.x. Epub 2011 Sep 23. PMID: 21883452

Manual de Psihiatrie a Copilului și Adolescentului, sub redactia Prof Dr Iuliana Dobrescu, Total Publishing, Volmul 1, Editia a II-a revizuita și adaugita, 2016, Bucuresti

Martinez, G., Mosconi, E., Daban-Huard, C., Parellada, M., Fananas, L., Gaillard, R., Fatjo-Vilas, M., Krebs, M. O., \& Amado, I. (2019). "A circle and a triangle dancing together": Alteration of social cognition în schizophrenia compared to autism spectrum disorders. Schizophrenia research, 210, 94-100. https://doi.org/10.1016/j.schres.2019.05.04 3

McPartland, J., \& Volkmar, F. R. (2012). Autism and related disorders. Handbook of clinical neurology, 106, $407-418$. https://doi.org/10.1016/B978-o-44452002-9.00023-1

Merleau-Ponty M. Vizibilul și invizibilul, Ed. Tact, Cluj-Napoca, 2017

Middeldorp, C. M., Hammerschlag, A. R., Ouwens, K. G., Groen-Blokhuis, M. M., Pourcain, B. S., Greven, C. U., Pappa, I., Tiesler, C., Ang, W., Nolte, I. M., VilorTejedor, N., Bacelis, J., Ebejer, J. L., Zhao, H., Davies, G. E., Ehli, E. A., Evans, D. M., Fedko, I. O., Guxens, M., Hottenga, J. J., ... Boomsma, D. I. (2016). A Genome-Wide Association MetaAnalysis of AttentionDeficit/Hyperactivity Disorder Symptoms în Population-Based Pediatric Cohorts. Journal of the American Academy of Child and Adolescent Psychiatry, 55(10), 896905.e6.

https://doi.org/10.1016/j.jaac.2016.05.0 25

Mihailescu V. Antropologie. Cinci introduceri. Ed Polirom, 2009, pp25-40 ISBN: 978-973-46-1372-4

Pineda-Alhucema W, Aristizabal E, Escudero-Cabarcas J, Acosta-López JE, Vélez JI. Executive Function and Theory of Mind în Children with ADHD: a Systematic Review. Neuropsychol Rev. 2018 Sep;28(3):341358. doi: 10.1007/s11065-018-9381-9. Epub 2018 Aug 30. PMID: 30168020.

Ricks DM, Wing L. Language, communication, and the use of symbols în normal and autistic children. J Autism Child Schizophr. 1975 Sep;5(3):191-221. doi: 10.1007/BFo1538152. PMID: 1174124. 
Russel A Barkley, Attention-Deficit Hyperactivity Disorder A Handbook for diagnosis and treatment. Third Edition, 2006, The Guilford Press pp376)

Uekermann J, Kraemer M, Abdel-Hamid M, Schimmelmann BG, Hebebrand J, Daum I, Wiltfang J, Kis B. Social cognition în attention-deficit hyperactivity disorder (ADHD). Neurosci Biobehav Rev. 2010 Apr;34(5):734-43. doi: 10.1016/j.neubiorev.2009.10.009. Epub 2009 Oct 24. PMID: 19857516.

Vandekerckhove, M., Bulnes, L. C., \& Panksepp, J. (2014). The emergence of primary anoetic consciousness în episodic memory. Frontiers în behavioral neuroscience, 7, 210. https://doi.org/10.3389/fnbeh.2013.002 $\underline{10}$

Zhao, H., Nyholt, D.R. Gene-based analyses reveal novel genetic overlap and allelic heterogeneity across five major psychiatric disorders. Hum Genet 136, 263-274 (2017). https://doi.org/10.1007/so0439-0161755-6

${ }^{1}$ Asistent universitar dr. Disciplina Psihologie Medicală, Universitatea de Medicină și Farmacie „Iuliu Hațieganu” Cluj-Napoca, medic specialist psihiatrie pediatrică.

Email: bogdana.miclea@umfcluj.ro , bogdanamilea@yahoo.ro 


\title{
Preachiziții în învățarea scris-cititului la copiiii cu tulburări de invățare
}

\section{Ioana MATEI ${ }^{1}$}

\begin{abstract}
The first step in combating speech and language disorders, is checking if specific language development steps from infancy and toddlerhood have been done. Students from families with financial difficulties, that lack early childhood cognitive development, tend to be less skilled in reading or writing.

To avoid school dropout, we focused on identifying these issues when a child starts school and apply a ten week program.

This program has two components, one for teachers and the other for students. The main goal is to identify if certain early development milestones have been met, memory and atention development and phonology conscience. The program has proved it's eficacity even during the corona virus pandemic
\end{abstract}

Keywords: learning disabilities, early intervention, reading and writing

\section{Cadru teoretic}

Formarea deprinderilor de scris-citit constituie un obiectiv de o importanță deosebită în ciclul primar. A învăța pe micii școlari să citească și să scrie, în perspectiva evoluției lor intelectuale, înseamnă a-i învăța cum să învețe.

Se poate afirma că întreaga evoluție a elevilor, atât în școală, cât și în viață, depinde de măsura în care ei și-au însușit această deprindere, până la nivelul la care acesta să constituie un mijloc de autoinstruire.

Dobândirea competențelor de scris-citit va duce la ridicarea stimei de sine și - implicit - la evitarea abandonului școlar.

Este dificil de făcut un demers de definire a conceptului de dificultăți de învățare, datorită complexității acestui fenomen, dar și datorită faptului că există perspective diferite, distincte, asupra acestuia, în funcție de paradigma psihologică în care se abordează acest tablou patologic.

"În prezent, domeniul tulburărilor de învățare se confruntă cu o absență a unor criterii unitare de diagnostic. Consensul nu este obținut nici măcar la nivel european. În plus, coexistența a două sisteme de clasificare importante (Manualul de diagnostic și statistică a tulburărilor mentale, ediția a 5-a, 2013, respectiv Clasificarea internațională a bolilor, 1993), dar care nu sunt concordante sub aspectul acestor criterii, face mai dificil demersul de diagnosticare și evaluare. De asemenea, în raport cu recunoașterea formală a acestor tulburări, tarile diferă sub aspectul impunerii unor standarde diagnostice și al varietății instrumentelor formale utilizate.(Roșan, David, 2017, p.9).

O dificultate de învățare se referă la o întârziere, o tulburare, o dezvoltare încetinită în plan emoțional sau comportamental, însă nu este rezultatul unei întârzieri mintale. Este semnalată astfel o necesitate care vine din domeniul practicii școlare efective.

O parte dintre tulburările limbajului scris-citit se datorează unei imaturităţi şcolare. Aceşti copii prezintă întârzieri în sfera proceselor cognitive de tip 
senzorial, care influențează negativ acuitatea perceptivă şi receptarea adecvată, în special a stimulilor vizuali şi auditivi. Uneori copiii nu pot percepe şi diferenţia la nivel de fonem - grafem și nu pot stabili legături între simbolurile grafice. Toate aceste aspecte ale imaturităţii şcolare (care intră fie în categoria tulburărilor de dezvoltare, fie în categoria tulburărilor de învăţare) fac să apară greutăţi în însuşirea scriscititului, $\mathrm{cu}$ aspecte comune dislexieidisgrafiei, dar care în mare parte nu sunt dislexii-disgrafii. (Raus, Botezatu, Fărâmă, 2006)

Limbajul oral se dezvoltă pe baza preachizițiilor limbajului și a elementelor de psihomotricitate, iar limbajul oral stă la baza achiziției limbajului scris-citit. (Bodea-Hațegan, 2016).

Evaluarea preachizițiilor limbajului este un proces complex și amplu, dar care abordat terapeutic duce la dezvoltarea limbajului oral și implicit la facilitarea învațării limbajului scris-citit. Factorii de care depinde formarea deprinderilor de scris-citit poartă numele de preachiziții ale limbajului.

"Prima etapă în prevenirea apariției dificultăților de învățare este cea a structurării preachizițiilor. Preachizițiile asupra cărora țintesc demersurile de evaluare/prevenire sau intervenție sunt: orientare spațio-temporală, coordonarea motorie (coordonarea grupelor musculare de la nivelul aparatului fonoarticulator, coordonarea grupelor musculare de la nivelul mâinii, cordonare ochi-mână), procesare fonologică, lateralitate, procesare vizuală, motricitate generală/fină, schemă corporală” (Bodea-Hațegan, 2016).
Principala problemă a copiilor din mediile defavorizate este aceea că aceștia nu au participat (sau participă cu o frecvență redusă) la activitățile desfașurate în gradiniță. Astfel, învățătoarea - în clasa pregatitoare trebuie să pună un accent deosebit pe recuperarea și dezvoltarea preachizițiilor limbajului.

Focalizarea pe formarea și dezvoltarea aptitudinilor de școlaritate este deosebit de important, asigurând prevenția insuccesului școlar sau a eșecului școlar. (Burlea, 2007; Burlea, Milici, 2008)

Dificultățile de învațare afectează cel puțin 1 din 10 copii de școală. Definirea dificultăţilor de învăţare este necesară pentru a realiza o concordanţă între nevoile reale ale practicii educaţionale şi conceptualizarea lor. Este acceptată existența unui număr mare de copii care prezintă dificultăţi de învățare, cel puţin o scurtă perioadă de timp din şcolaritatea lor. Practic, nu există copil care să nu întâmpine greutăţi măcar o dată în învățarea din şcoală. Pe de altă parte, sfera învățării umane este mult mai largă decât învățarea școlară. (BălașBaconschi, 2010)

\section{Descrierea studiului derulat și a rezultatelor obținute}

În acest scop, este important să identificăm nivelul preachizițiilor și nivelul de dezvoltare cognitivă a copiilor de clasa pregatitoare și clasa I din școala noastră, care are un specific aparte. $90 \%$ dintre copii proveniți din medii sociale defavorizate.

Obiectivele cercetării au fost: realizarea unui program de intervenție pentru prevenirea apariției și corectarea 
tulburărilor de scris-citit la școlarii mici; aplicarea programului unor grupuri de școlari proveniți din medii sociale defavorizate; monitorizarea însușirii preachizițiilor limbajului la copiii implicați; realizarea și aplicarea unor probe de evaluare în etapa inițială și cea finală a cercetării.

Cercetarea de față pornește de la două ipoteze:

-Participarea la un program de evaluare și intervenţie personalizat bazat pe structurarea preachizițiilor limbajului contribuie la învățarea mai eficientă a scris-cititului la școlarii mici cu tulburări/dificultăţi de învăţare proveniți din medii sociale defavorizate.

-Dobândirea competenţelor de scriscitit vor duce la ridicarea stimei de sine şi implicit la evitarea abandonului şcolar.

Pentru atingerea obiectivelor și verificarea ipotezelor mai sus enunțate, s-a apelat la evaluarea nivelului de preachiziții prin probe de evaluare și aplicarea timp de 10 săptămâni a unui program de intervenție.

Cercetarea de față s-a efectuat în cursul anului școlar 2019-2020 în cadrul Școlii Gimnaziale "Traian Dârjan", iar intervenția propriu-zisă a avut loc în perioada Septembrie 2019 - Iunie 2020.

S-au examinat un număr de 25 de copii, cu vârsta între 6-8 ani, în Școala Gimnazială "Traian Dârjan" Cluj-Napoca. Dintre aceștia 13 sunt fete și 12 sunt băieți. Criteriul selecției subiecților pentru cercetare a fost cel al vârstei. Pentru 13 elevi s-a aplicat programul de intervenție (elevii clasei CP A), iar 12 elevi au rămas grupul de control (elevii clasei CP B). Evaluarea s-a făcut individual în cabinetul logopedic, iar intervenția s-a făcut la clasă, în colaborare cu învațătorii de la clasă.

S-au aplicat probele la două clase pregătitoare. La clasa pregătitoare A s-a aplicat programul de intervenție timp de 10 săptămâni. Clasa pregătitoare B e grup de control.

În scopul elaborării cercetării s-au utilizat o serie de metode de investigare care au fost utile în aprofundarea temei propuse.

Astfel, pentru a duce la bun sfârşit cercetarea s-au folosit: observaţia, convorbirea, explicaţia, exerciţiul, studiul bibliografic, probă pentru cunoașterea vârstei psihologice a limbajului - Alice Descoeudres, Proba de evaluare a abilităților morfologice în limba română, Probă de evaluare - clasa pregătitoare.

Proba de evaluare a abilităților morfologice în limba română - PEAMLR realizată de Bodea-Hațegan (2014) este o probă adaptată după Test for Reception of Grammar - TROG. Proba permite stabilirea nivelului comprehensiunii verbale, cu focalizare asupra abilităților de receptare a categoriilor gramaticale. Proba constă în nouăzeci şi doi (92) de itemi, patru pentru fiecare dintre aspectele gramaticale abordate, fiecare item al probei este redat imagistic, iar sarcina copilului este aceea de a indica imaginea corespunzătoare itemului.

Probă pentru cunoașterea vârstei psihologice a limbajului - Alice Descoudres: Testul de stabilire a vârstei psihologice a limbajului adaptat după 
Alice Descoeudres este o probă care se poate aplica la copii de de la 2 ani până la vârsta de 7 ani. Această probă conține șapte subteste, care vizează dezvoltarea gândirii și a limbajului. (Vrășmaș, Oprea, 2003).

Probe de evaluare - clasa pregătitoare: Proba este creată pentru evaluarea preachizițiilor limbajului scris-citit.

S-a realizat un program marcat de o puternică trăsătură de aplicabilitate, datorită numărului mare de exerciții și fișe, care a devenit un instrument de lucru atât într-un program educativ aplicat la clasă pentru dobândirea și dezvoltarea preachizițiilor limbajului, cât și unul terapeutic-recuperator aplicat în cabinetul logopedic.

Programul a fost structurat pe 10 săptămâni. A fost aplicat la clasa pregătitoare $A$ de către învățătoare în colaborare cu profesorul logoped. Planul de intervenție este structurat pe 6 teme importante ale preachizițiilor scriscititului mai exact: schemă corporală, lateralitate, orientare spaţio-temporală, serialitate, conștiință fonologică, atenție și memorie.

Ghidul pentru învățători este completat cu un program de intervenție: 90 de fișe de lucru, destinate copiilor din clasa pregătitoare, grupate pe cele 6 teme (schemă corporală, lateralitate, orientare spațio-temporală, serialitate, conștiință fonologică, atenție și memorie structurate).

Rezultatele obținute de ambele grupe în evaluarea inițială sunt la același nivel, nu se observă diferențe semnificative între participanți. În următoarea etapă a cercetării, participanții din lotul experimental au fost incluși într-un program de intervenție terapeutică personalizat, în timp ce la lotul de control nu au fost aplicate nici un fel de programe personalizate.

Elevii din eșantionul de control au înregistrat un progres ușor față de perioada iniţială, datorat participării la activitățile clasei pregătitoare. Ei încă mai întâmpină dificultăţi semnificative. Au chiar și staționări sau un ușor regres, datorat absenteismului școlar, dar și perioadei de pandemie. Dupa cum arată și rezultatele din evaluarea inițială, dar și cele din evaluarea finală, pregătirea pentru începerea scris-cititului nu s-a realizat eficient.

Elevii din eșantionul experimental au înregistrat un progres semnificativ faţă de perioada iniţială, datorat participării la programul de intervenție. Aceasta se poate observa din studierea mediilor la probele inițiale și la cele finale.

În evaluarea inițială grupul experimental a obținut următoarele rezultate:

- la proba PEAMLR: o medie de 53 care corespunde centilului 5 / dificultate mintală ușoară / dificultăți de învățare conform etalonului orientativ,

- la proba Alice Descoudres: o medie a vârstei psihologice a limbajului de 4,73 (iar media vârstei reale fiind de $6,28)$,

- la proba de evaluare: 49, 15 corespunde calificativului Suficient, aproape de limita de jos.

În evaluarea finală, grupul experimental a obținut următoarele rezultate: 
- la proba PEAMLR: o medie de 73, care corespunde centilului $7 /$ valizi conform etalonului orientativ,

- la proba Alice Descoudres: o medie a vârstei psihologice a limbajului de 6 , 37 (iar media vârstei reale fiind de $6,28)$,

- la proba de evaluare: 65,69 corespunde calificativului Bine.

În evaluarea inițială, grupul de control a obținut următoarele rezultate:

- la proba PEAMLR: o medie de 56,8 care corespunde centilului 5 / dificultate mintală ușoară / dificultăti de învățare conform etalonului orientativ,

- la proba Alice Descoudres: o medie a vârstei psihologice a limbajului de 4,67 (iar media vârstei reale fiind de 6,27),

- la proba de evaluare: 45,15 corespunde calificativului Suficient, aproape de limita de jos.

În evaluarea finală, grupul de control a obținut următoarele rezultate:

- la proba PEAMLR: o medie de 58,5 care corespunde centilului $5 /$ dificultate mintală ușoară conform etalonului orientativ,

- la proba Alice Descoudres: o medie a vârstei psihologice a limbajului de 5,38, iar media vârstei reale fiind de 6,27 (aici s-a inregistrat chiar o scădere semnificativă datorată absenteismului școlar, dar si perioadei de pademie),

-la proba de evaluare: 47,7 corespunde calificativului Suficient, la limită.

Programul de intervenție și dezvoltare a peachizițiilor limbajului, atât pentru cadrele didactice, cât și pentru elevi, structurat pe 10 săptămani, a evidențiat ritmurile specifice de dezvoltare a copiilor, precum și viteza cu care se recuperează. Din analiza datelor rezultă că elevii din grupul experimental înregistrează medii semnificativ mai mari decât cei din grupul de control.

Figura 1- Rezultate obținute la proba PEAMLR - Grup experimental

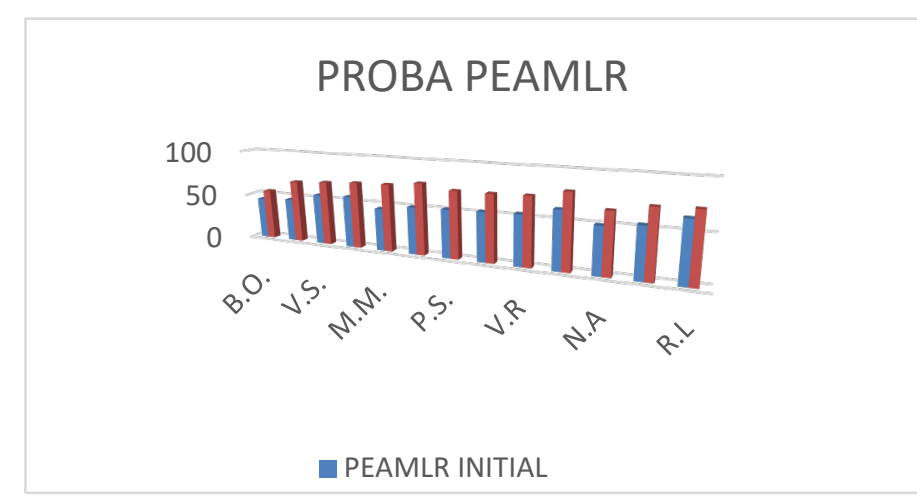

Figura 2 Rezultate obținite la proba PEAMLR - Grup control

Grup control PEAMLR

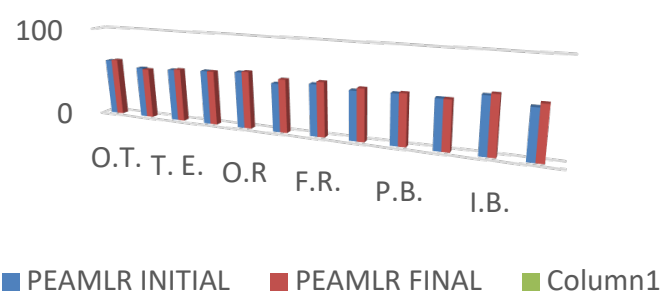

Elevii din grupul experimental au înregistrat un progres semificativ în ceea ce privește nivelul atins pentru proba PEAMLR. S-au dovedit a fi mult mai receptivi la asimilarea semnificaţiei noilor cuvinte şi la integrarea lor în enunțuri. Tot progres au înregistrat și elevii din grupul de control, însă majoritatea dintre ei încă mai întâmpină dificultăţi în utilizarea noilor cuvinte în enunţuri. 
În evaluarea inițială elevii au întâmpinat dificultăți la nivelul următoarelor categorii morfologice: categorii morfemice care definesc verbul (mod, timp, diateză); prepoziții compuse; conjuncții coordonatoare; morfeme derivative; morfeme suprasegmentale; categoriile morfematice care asigură performanțe crescute (articol, gen, pronume; numeral cardinal; numeral ordinal; morfeme număr). Astfel, în cabinetul logopedic prin fișele personalizate am pus accent pe dezvoltarea și fixarea acestor categorii morfemice. Astfel, în evaluarea finală se observă o creștere semnificativă a rezultatelor.

Figura 3 Rezultate obținute la proba Alice Descoudres - Grup experimental

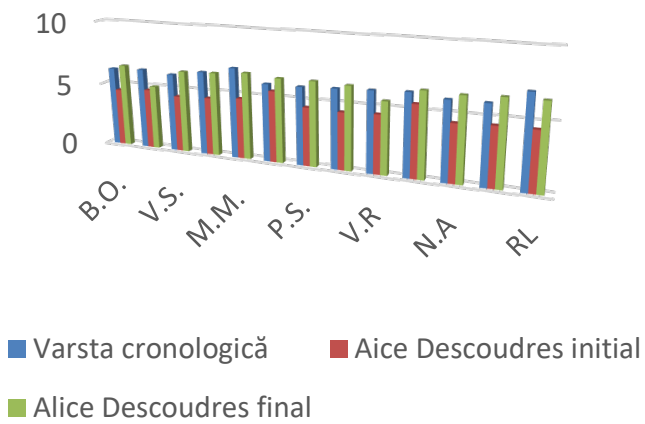

În cazul elevilor din grupul experimental, s-a constatat un progres semnificativ în atingerea subtestului 3, memorarea. Aceasta s-a datorat exercițiilor realizate în timpul programului, exerciții care au vizat antrenarea atenției și a memoriei de lucru. S-au realizat cu succes jocuri de atenție de tipul: "Jocul perechilor", "Jocul umbrelor", "Jocul diferențelor" și jocuri de memorie. S-a realizat un progres semnificativ și la subtestul 2, completarea lacunelor într-un text.
Figura 4 Rezultate obținute la proba Alice Descoudres - Grup control

\section{Grup de control-Proba Alice Descoudres}

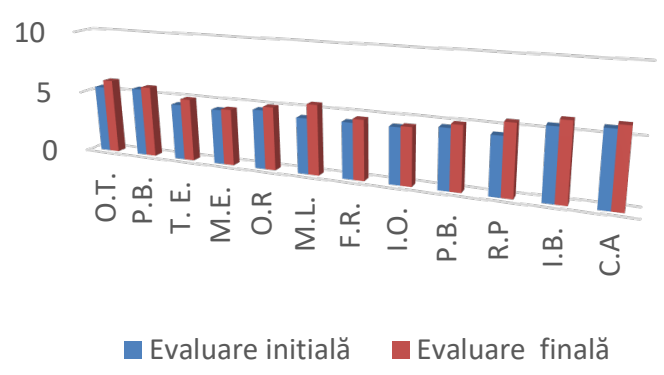

Dacă în evaluarea inițială majoritatea dădeau răspunsuri la întamplare, fără să înțeleagă aproape deloc textul, acum datorită programului de intervenție majoritatea reușesc să înțeleagă un text scurt. Jocurile din programul de interventie de tipul Băiatul / fetița spune..., exercițiile de diferențiere și succesiune, memorare a zilelor săptămânii: "Mergi în ritmul dat de mine!", "Baloanele cu zilele săptămânii", precum și exercițiul-joc de asociere a momentelor zilei cu activităţile corespunzătoare ("Orarul în imagini") au ajutat foarte mult la atingerea acestui obiectiv.

Datorită exercițiilor din fișele de lucru, acum majoritatea cunosc toate culorile și cele primare și secundare și nu mai dau raspunsuri la întamplare. Toate acestea au dus la creșterea punctajului la aceasta probă și apropierea vârstei psihologice a limbajului de vârsta reală comparativ cu grupul de control unde acest lucru nu s-a realizat, ba chiar s-a înregistrat o ușoară scădere. 
Figura 5 Rezultate obținute la Proba de evaluare pentru clasa pregătitoare - Grup experimental

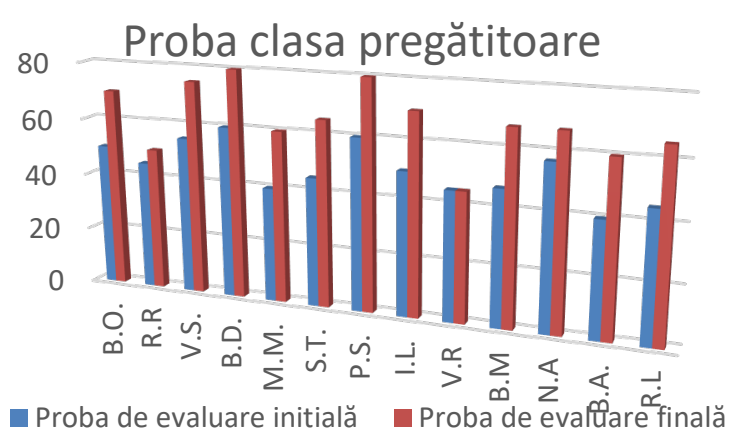

Figura.6 Rezultate obținute la Proba de evaluare pentru clasa pregătitoare - Grup de control

\section{Grup de control- Probă de evaluare}

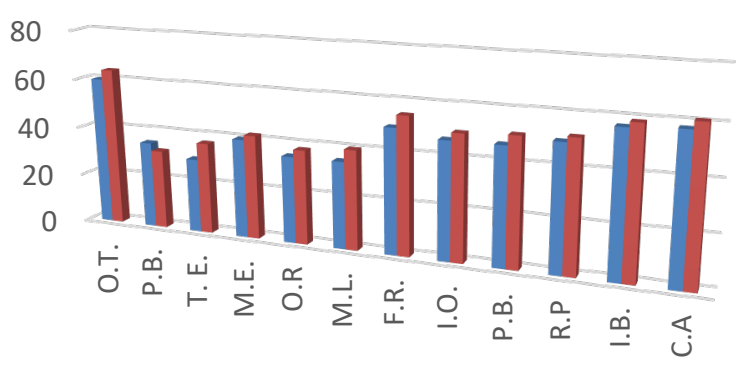

- Proba de evaluare initială $\quad$ Proba de evaluare fina

Elevii din grupul experimental au înregistrat un progres însemnat în atingerea (într-o proporţie mult mai mare) standardului privind formarea deprinderilor de exprimare orală. Se străduiesc să răspundă corect şi în propoziţie la întrebările care le sunt adresate, identifică sinonimele şi antonimele cuvintelor date, într-o proporţie mult mai mare. Elevii din grupul experimental formulează clar şi concis întrebări şi utilizează formulele de politețe în comunicarea cu ceilalți. Unii elevi mai întâmpină dificultăți în formularea de mesaje din cel puţin trei propoziţii aşezate într-o ordine logică.
Majoritatea operează cu noțiuni de relații spațiale, reușesc să se orienteze temporal, operează cu noțiuni legate de timp și au început să dezvolte structuri spațio-temporale. $\mathrm{Nu}$ sunt conștienți încă de rimă, nu știu un lucru: cuvintele pot rima. În schimb, nu întâmpină probleme cu exercițiile de ritm și preferă exercițiile de serialitate. Cele mai mari progrese s-au realizat la nivelul conștiinței fonologice. În evaluarea inițială nu aveau nici o noțiune legată de propoziție, cuvânt, silabă. Jocuri și exerciții din programul terapeutic:

-repetarea de cuvinte necunoscute din ce în ce mai complicate din punct de vedere fonologic;

- manipularea silabelor la începutul sau la sfârşitul cuvintelor;

-localizarea, recunoașterea silabei dintr-un cuvânt și localizarea poziției sale;

-identificarea celor două silabe dintrun cuvânt, substituirea silabei finale cu cea iniţială şi invers;

- exerciţii ce urmăresc aceleaşi obiective ca în etapa silabelor: localizarea, izolarea, identificarea intrusului, eliminarea sau adăugarea sunetelor, memorarea după auz a unor cuvinte şi propoziţii menţionate pentru sunetul vizat.

Aceste jocuri și exerciții din programul terapeutic au dus la obținerea unui punctaj ridicat de către majoritatea elevilor în etapa de evaluare finală. Acum sunt capabili să facă legături între ce aud și ce se scrie, încep să vadă corespondența dintre desfășurarea în timp și spațiu a scis-cititului, să cunoască codul alfabetic. 
În cazul elevilor din grupul de control, progresul înregistrat a fost mai mic. Problemele pe care le întâmpină se referă la despărțirea cuvintelor în silabe și la identificarea sunetelor în cuvânt. Dificultăți întâmpină și la identificarea proprietăților și la aranjarea imaginilor în succesiune, iar vocabularul rămâne sărac. Astfel, în analiza comparativă între procentajul elevilor din grupul experimental și cel de control, se observă diferențe majore în ceea ce privește atingerea în totalitate a obiectivelor de performanță propuse. În activităţile de învăţare, elevii au fost încurajaţi în permanență să se manifeste, să-şi exprime ideile, să-şi asume roluri şi responsabilităţi.

\section{Concluzii}

Performanțele în învățarea preachizițiilor limbajului atinse de elevii grupului experimental nu sunt percepute doar de către adulţi / cadre didactice. Ei înșiși percep aceste performanțe şi se responsabilizează în rezolvarea sarcinilor de lucru. De asemenea, ei înţeleg și obs ervă că implicarea lor este importantă. Ei manifestă dorinţa de a rezolva cât mai des fișele de lucru puse la dispoziția lor permanent, pentru a se face vizibili în rândul colegilor.

Din analiza datelor obținute de către cele două grupe de participanți, concluzionăm că preachizițiile limbajului deficitare sau nefuncționale pot duce la TSI, dar intervenind din timp asupra lor, stimulându-le dezvoltarea, ajungem la îmbunătățirea performanțelor școlare ale elevilor. Considerăm că evaluarea timpurie a preachizițiilor limbajului la începutul clasei pregătitoare ar putea fi de mare folos în identificarea și diagnosticarea precoce a elevilor expuși riscului de a dezvolta tulburări specifice de învățare.

Recomandăm implementarea unor programe de depistări precoce a preachizițiilor limbajului în scop preventive din clasa pregătitoare, utilizarea probelor de evaluare selectate în cercetare în evaluarea elevilor aflați în clasa pregătitoare din ciclul primar, iar rezultatele obținute pot fi urmărite longitudinal în viitor la clasele primare. Pe baza evaluării cu probele aplicate în cercetare, se pot elabora proiecte recuperatorii și educative speciale $\mathrm{cu}$ scopul de-a preveni instalarea TSI și a asigura succesul școlar al copiilor.

\section{Bibliografie}

Bălaș-Baconschi, C. (2010). Psihopedagogia copiilor cu dificultăți de învățare, suport de curs universitar de la Facultatea de Psihologie și Științe ale Educației, Cluj-Napoca: UBB.

Bodea Haţegan, C. (2016). Logopedia. Terapia tulburarilor de limbaj. Structuri deschise, Bucureșt: Editura Trei.

Bodea Hațegan, C. (2014). Abordări terapeutice ale limbajului. Perspective actuale, vol. I , ClujNapoca: Presa Universitară Clujeană.

Burlea G. (2007). Tulburarile limbajului scris-citit, Iași: Editura Polirom.

Burlea, G., Milici, R. C. (2008). Exerciții pentru formarea și dezvoltarea aptitudinilor de școlaritate, Iași: Editura Polirom.

Raus G., Botezatu V., Fărâmă M. (2006). Formarea comportamentului lexic şi 
grafic la copilul cu dificultăți de învăţare, Iași, in Academia Edu, retrived from https://www.academia.edu/31051760/ Carte Comportamentul Lexic Grafic in 20.03.2021

David C., Roșan A. ( 2017). Repere diagnostice bazate pe dovezi științifice în tulburările specifice de învățare, Cluj-Napoca: , Editura Argonaut/ Limes.

Vrășmaș, E., Oprea, V. (2003). Set de instrumente, probe şi teste pentru evaluarea educaţională a copiilor cu dizabilităti, București: Editura Mar Link

1 Prof. logoped CJRAE Cluj - Școala

"Traian Dârjan" Cluj-Napoca

E-mail: ioanamatei8o@yahoo.com 


\title{
Preachiziții în învățarea scris-cititului la copiii cu tulburări de invățare
}

\section{Florentina Mihaela MOȘNEAG ${ }^{1}$}

\begin{abstract}
According to the literature, we are talking about a language delay when the child fails to reach the level of language evolution, compared to his chronological age. In fact, we know that language development is closely linked to cognitive development. Therefore, the structure of language is influenced by the degree of cognitive development. Knowing that the language delay may exists as a secondary pathology in most intellectual disabilities and can be recognized by the poverty of vocabulary, the inability to express themselves correctly in sentences or phrases, being reached phonetic, lexical and grammatical aspects, I wanted to surprise in this study the features of language development in young children oriented towards our school by proposing a complex, multidimensional approach to early assessment of language skills and capturing the effect of a multidimensional intervention program that will ultimately lead to the configuration of functional communication skills. Children included in this study are enrolled in the kindergarten group or in the preparatory class, aged between 4 and 8 years. These children are also diagnosed with mild or moderate intellectual disability.

The program took place in two stages. In the first stage, a multidimensional evaluation was performed, on all sides of the language by applying tests, scales or evaluation tests. The results obtained by the children were interpreted and presented at the level of some case studies. In the second stage, we proposed an intervention program that aims to enrich and activate vocabulary, by applying the "50 word-list technique$T^{50 "}$, training phonetic and phonological skills, those related to structural semantics and lexical semantics and shaping morphological skills, which will lead to the configuration of a functional communication skill related to chronological and mental age.
\end{abstract}

Keywords: language delay, communication skills, early assessment of language skills, multidimensional intervention program.

\section{Introducere}

Limbajul este o componentă proprie creierului uman, datorită utilizării în timpul producerii lui a unui sistem arbitrar de semne: limba, de natura fie sonoră, fie vizuală. Născut din nevoia de comunicare cu aproapele, limbajul înseamnă folosirea unui cod, dar cu particularitățile individuale, în cadrul aceluiași grup social. Deși folosește același cod, adică limba, limbajul reprezintă folosirea limbii la nivel individual; în acest sens, limba poate fi considerată un instrument, pe care fiecare persoană îl folosește când vrea, când poate, dar mai ales cum poate, având $\mathrm{o}$ funcționare condiționată multifactorial (Burlea, 2007).
Vorbim de întârziere în dezvoltarea limbajului atunci când copilul nu reușește să atingă nivelul de evoluție al limbajului, raportat la vârsta sa cronologică. De obicei, această întârziere există ca fenomene secundare în mai toate dizabilitățile de intelect și senzoriale dar se pot manifesta și de sine stătător.

Întârzierea în dezvoltarea limbajului se recunoaște după sărăcia vocabularului și după neputința de a se exprima corect, logic în propoziții și fraze. Frecvent, întârzierile de dezvoltare a limbajului cuprind atât aspectele fonetice, lexicale, cât și gramaticale. Datorită acestor fenomene, și înțelegerea vorbirii 
celor din jur se realizează cu dificultate, ceea ce înfluențează negativ evoluția psihică generală și comportamentală. Asemenea întârzieri pot fi determinate de carențele sistemului nervos central provocate de hemoragii cerebrale în timpul nașterii, de eventuale boli grave, de lipsa de stimulare a comunicării în perioada primei copilării (Avramescu, 2007).

Psihologi de prestigiu subliniază relaţia dintre dezvoltarea intelectuală şi dezvoltarea limbajului. Dezvoltarea limbajului în general, este tributară dezvoltării intelectuale. Pentru a învăţa să vorbești, trebuie să poți înțelege (Delacroix). Din acest punct de vedere, cercetările lui Vâgotski, care consideră limbajul ca instrument al dezvoltării mentale, şi ale lui Luria şi Kendler, în concepţia cărora limbajul joacă rolul de reglator al comportamentului şi al activităţii voluntare, stabilesc semnificaţia limbajului pentru dezvoltarea psihicului, în general, şi a gândirii conceptualizate, în special. La copiii cu dizabiliate intelectuală, structura limbajului este influențată de gradul acesteia, deoarece utilizarea cuvintelor, a propoziţiilor, a frazelor şi a înţelegerii semnificației lor depind de capacitatea de asimilare a gândirii (Tatiana Slama-Cazacu, 1999) şi mai puţin de nevoile și interesele copilului.

Toate aspectele evidenţiate cu privire la întârzierea în dezvoltarea limbajului şi al relaţiei acestuia cu disfazia se regăsesc şi în cazurile de dizabilitate intelectuală, cu o simptomatologie generată de vidul mental şi de etiologia determinantă care a influenţat structurile neuropsihice în condiţiile date. La aceste caracteristici se adaugă şi o fenomenologie rezultată din particularităţile de structură anatomică şi psihică, specifică dizabilității respective. Formele cele mai accentuate ale tulburărilor de limbaj se întâlnesc în dizabilitatea intelectuală, şi cum aceasta are grade diferite, de la uşor la sever şi profund, dificultăţile de limbaj se prezintă pe o ierarhie foarte diversă și complexă. Întârzierea în dezvoltarea limbajului ocupă un loc central pe această scară și are implicaţii extinse, atât în desfaşurarea activităţii psihice generale, cât şi a comportamentelor adaptative (Preda, 2007).

Datorită varietății dificultăților din cadrul diagnosticului, dezvoltarea vorbirii și intervenția în întârzierea de dezvoltare a limbajului pot lua multe forme. Law et al. (200o) definesc abordările intervenției folosind trei categorii: didactice (instruire directă a comportamentelor lingvistice), naturaliste (învățarea copilului să răspundă eficient la cerințele lingvistice ale mediului) și hibride (o combinație între didactic și naturalist). Acești termeni oferă un cadru util pentru a contura abordări ale intervenției, deși, un terapeut poate folosi o abordare eclectică și poate adapta intervențiile în funcție de răspunsul clientului (Law, J., Garrett, Z., Nye, C. , 2005)

Demersul de intervenție în contextul întârzierii în dezvoltarea limbajului poate fi nuanțat în funcție de următorii parametrii (Bodea Hațegan, 2016):

-Vârsta cronologică la care s-a realizat diagnosticarea;

-Factorii de mediu care interferează cu evoluția tipică;

-Specificitatea simptomatologică; 
- Severitatea

tabloului

simptomatologic;

- Tehnica listei celor 50 de cuvinte - $\mathrm{T}^{50}$

În programul terapeutic abordat în problematica dezvoltării limbajului a fost folosită o tehnică terapeutică specifică elaborată de Carolina Bodea Hațegan Tehnica listei celor 50 de cuvinte - $\mathrm{T}^{50}$. Această tehnică a fost implementată la nivelul unor studii de caz, în mod empiric. Ea a fost elaborată și experimentată ca urmare a concluziilor subliniate de Petionou, Spanoudis (2014, apud Bodea Hațegan, 2016) cu privire la întârzierea în dezvoltarea limbajului. Aceștia subliniază faptul că, de obicei, diagnosticul de întârziere în dezvoltarea limbajului se stabilește atunci când copilul are un ritm încetinit de achiziție a limbajului, apar discrepanțe între dezvoltarea abilităților lingvistice și vârsta cronologică a copilului, iar în aceste condiții volumul vocabularului este redus, de obicei, la mai puțin de 50 de cuvinte.

Această tehnică presupune întocmirea unei liste de cuvinte ce urmează a fi învățate, reactualizarea cuvintelor de către copil după modelul terapeutului, modelarea pronunției cuvintelor de către terapeut, generalizarea utilizării cuvintelor de către părinte în mediul familial, prin abordarea naturală a conversației.

Lista trebuie să conțină cuvinte simple din punct de vedere fonetic, care nu ridică dificultăți articulatorii majore, cuvinte care odată însușite facilitează și inserția copilului în grupul de prieteni, colegi, facilitează stabilirea de relații comunicaționale adecvate cu părinții.
Este recomandat ca $\mathrm{T}^{50}$ să fie implementată până în momentul în care copilul reușește să pronunțe corect cele 50 de cuvinte din listă. Se poate realiza și un profil de achiziție a cuvintelor, iar cuvintele pe care copilul le poate pronunța corect sau care sunt în curs de modelare trebuie prezentate și părintelui pentru ca acesta, în mediul familiar, să asigure generalizarea utilizării lor corecte (Bodea Hațegan, 2016).

\section{Metodologia cercetării}

\section{Oijiectivele cercetărī}

Evidențierea

particularităților de dezvoltare a limbajului la copiii de vârsta mică cu dizabilitate intelectuală;

Propunerea unui demers complex, multidimensionat (pe toate laturile limbajului) pentru evaluarea timpurie a abilităților lingvistice;

Surprinderea efectului unui program de intervenție multidimensionat;

\section{Ipoteze}

Există o relație între utilizarea $T^{50}$ și dezvoltarea abilităților lexico-semantice;

Există relații între dezvoltarea abilităților lexico-semantice și conturarea morfologică în contextul întârzierii în dezvoltare;

Programul de intervenție multidimensionat conduce la configurarea unei competențe de comunicare funcționale;

\section{Prezentarea lotului de suliecti}

În prezentul studiu au fost incluși un număr de 5 copii ( 2 băieți și 3 fete) care prezintă semne ale întârzierii în dezvoltarea limbajului. Aceștia provin din grupele de grădiniță și clasa 
pregătitoare ai Centrului Școlar pentru Educație Incluzivă „,Speranța”, Zalău și prezintă, conform certificatului de orientare școlară și profesională, întârzieri ușoare și medii în dezvoltarea intelectuală. Prezentul studiu s-a desfășurat în perioada septembrie 2019august 2020.

\section{Descrierea înstrumentarului utilizat}

Pentru evaluarea copiilor au fost utilizate metode variate incluzând observarea lor în diverse medii, anamneza, intervievarea celor care cunosc copilul dar și probe, scale și teste standardizate:

-Scala de Dezvoltare Portage- este un test de evaluare a copiilor mici (cu vârste de până la 6 ani)

-Scala integrată de dezvoltare - acest instrument a fost tradus și adaptat pentru pentru limba română în anul 2012 sub coordonarea lui Anca și Bodea Hațegan și este o scală care redă abilități din următoarele domenii: ascultarea/audiția, limbajul receptiv, limbajul expresiv, vorbirea, cogniţia, comunicarea.

-Proba pentru cunoașterea vârstei psihologice a limbajului adaptată după Alice Descoeudres - cuprinde 7 probe, fiecare stabilind o anumită vârstă a limbajului pentru aspectul pe care îl vizează.

-Scala pentru stabilirea nivelul de dezvoltare a limbajului - Scala permite stabilirea corectă a diagnosticului de întârziere în apariția și dezvoltarea limbajului.

- „Pași prin lumea sunetelor”- Aplicația "Pași prin lumea sunetelor!" este un instrument elaborat de Carolina Bodea - Hațegan și Dorina Talaș, cu sprijinul Cochlear România și al ASTTLR.

-Probă de evaluare a abilităților morfologice în limba română - Proba a fost elaborată de către Carolina Bodea-Haţegan în anul 2014 în vederea evaluării laturii morfologice a limbajului.

\section{Procedura de Iucru}

Programul s-a desfășurat în două etape: evaluare inițială, în care au fost surprinse particularitățile de dezvoltare a limbajului la copiii de vârstă mică cu dizabilități intelectuale ușoare și moderate și a doua etapă de implementare a unui program de intervenție multidimensionat la copii evaluați și surprinderea efectului programului propus. Frecvența întâlnirilor în cadrul ședințelor de terapie a fost de una sau două pe săptămână cu o durată de aproximativ 40 de minute.

În prima etapă, a evaluării, au fost aplicate probele, testele și scalele prezentate anterior. Acestea au fost aplicate individual, în medii adecvate, timpul de administrare variind de la caz la caz. De asemenea au fost culese date din interviurile cu părinții, cadrele didactice de la clasă sau din echipa multidisciplinară și din documentele medicale ale fiecărui copil.

În cadrul celei de-a doua etape, s-a elaborat și implementat programul de intervenție. În implementarea programului s-a utilizat Tehnica listei celor 50 de cuvinte $-\mathrm{T}^{50}$. Activitățile specifice acestei tehnici au fost introduse la începutul ședințelor terapeutice, urmând ca la fiecare nouă ședință să se recapituleze cuvintele învățate anterior. 
Copiilor le-au fost prezentate cuvintele care urmează să fie învățate, aceștia având sarcina de a reproduce cuvântul auzit. În cazul în care pronunția era defectuoasă s-a încercat corectarea acesteia fără însă a insista, conform recomandărilor $\mathrm{T}^{50}$. Listele de cuvinte au fost abordate fragmentat în funcție de potențialul și evoluția fiecărui copil. A avut loc o notare ritmică a cuvintelor însușite. După această etapă a ședinței sa recurs la un set de exerciții pentru dezvoltarea conștiinței fonologice care cuprinde o parte din cuvintele aflate în liste. Exercițiile desfășurate în vederea dezvoltării conștiinței fonologice au fost adaptate după un set de itemi care testau abilitățile lingvistice ale elevilor preșcolari din Norvegia în cadrul unui studiu desfașurat de S.A.H. Lyster, A. O. Lerva, și C. Hulme (2016). Cuvintele și imaginile au fost atent alese astfel încât unele se regăsesc printre cuvintele incluse în Lista celor 50 de cuvinte, pentru a facilita înțelegerea acestora, iar pentru altele criteriile de selecție au fost: să fie ușor de recunoscut și să nu creeze dificultăți articulatorii majore, cuvinte accesibile copiilor din punct de vedere al pronunţiei, şi utile din punct de vedere al experienței și practicii educaționale.

Activitățile desfășurate pentru dezvoltarea conștiinței fonologice au implicat activități de identificare a fonemelor, de cobinare a fonemelor, identificarea unei imaginii când sunt date sunetele corespunzătoare, exerciții de numărare a fonemelor și eliminarea fonemelor inițiale, exerciții de despărțire în silabe, cu numărarea acestora, exerciții de combinare a cuvintelor în propoziție. $\mathrm{Au}$ fost introduse în această etapă și activități specifice pentru formarea abilităților de sesizare a rimei.

Exercițiile, privind dezvoltarea competențelor morfologice, au fost alese și implementate ca urmare a rezultatelor copiilor obținute la "Proba de Evaluare a Abilităţilor Morfologice în Limba Română. Aplicaţii psiholingvistice" (PEAMLR). În alegerea materialului lingvistic s-a urmărit introducerea cuvintelor nou învățate. Au fost folosite imagini însoțite de cerința de a identifica imaginea corespunzătoare enunțului, cum ar fi: ,Leul este in cușcă.”; „În coș sunt mere.” ; „,Trei copii se joacă.”, „, Al treilea balon este albastru.", Ei aleargă.; , Ochelarii sunt pe carte." De asemenea au fost desfășurate jocuri de genul ,, Eu spun una, tu spui mai multe", găsirea unui adjectiv potrivit pentru un substantiv sau verb dat, exerciții cu prepoziții simple și compuse, exerciții pentru însușirea conceptului de numerație și de recunoaștere a numeralelor ordinale. Demersul terapeutic a avut la bază obiectivele propuse.

\section{Evaluarea innitială}

În urma evaluărilor se observăm că cei 5 copii incluși în prezentul studiu prezintă întârziere în dezvoltarea limbajului pe fondul unei dizabilități intelectuale ușoare sau medii. Pe lângă întârzierea în dezvoltarea intelectuală copiii mai prezintă tulburări emoționale, întârziere psihomotrică, tulburări de conduită și deficit atențional iar , o parte din ei, provin dintr-un mediu policarențat. Toate aceste tablouri pot fi cauze ale întârzierii în dezvoltarea limbajului sau, cu alte cuvinte, întârzierea în dezvoltarea limbajului poate apărea pe un fond patologic. 


\begin{tabular}{|c|c|c|c|c|c|c|}
\hline $\begin{array}{l}\text { Nr. } \\
\text { crt. }\end{array}$ & $\begin{array}{l}\text { Nume și } \\
\text { prenume }\end{array}$ & $\begin{array}{l}\text { Încadrarea diagnostică } \\
\text { ( conform Certificatului de } \\
\text { orientare școlară și } \\
\text { profesională) }\end{array}$ & Sex & $\begin{array}{l}\text { Vârsta } \\
\text { cronologică }\end{array}$ & $\begin{array}{l}\text { Vârsta } \\
\text { mentală } \\
\text { (conform } \\
\text { Scalei } \\
\text { Portage) } \\
\end{array}$ & $\begin{array}{l}\text { IQ } \\
\text { (conform } \\
\text { Scalei } \\
\text { Portage) }\end{array}$ \\
\hline 1. & B.A.A. & $\begin{array}{l}\text { Tulburare de dezvoltare } \\
\text { intelectuală-retard psihic ușor, } \\
\text { deficit atențional, tulburări } \\
\text { emoționale, tulburare de } \\
\text { atașament, mediu policarențat }\end{array}$ & $\mathrm{F}$ & 8 ani & $\begin{array}{l}4 \text { ani și } 7 \\
\text { luni }\end{array}$ & 52 \\
\hline 2. & V.L. & $\begin{array}{l}\text { Retard psihic ușor, tulburări de } \\
\text { conduită și emoționale }\end{array}$ & $\mathrm{F}$ & $\begin{array}{l}7 \text { ani și } 10 \\
\text { luni }\end{array}$ & 5 ani & 64 \\
\hline 3. & L.A. & $\begin{array}{l}\text { Retard psihic ușor, sindrom } \\
\text { hiperkinetic, întârziere } \\
\text { psihomotrică }\end{array}$ & $\mathrm{M}$ & 4 ani și 5 luni & $\begin{array}{l}2 \text { ani și } 10 \\
\text { luni }\end{array}$ & 64 \\
\hline 4. & B.B.I. & $\begin{array}{l}\text { Tuburări emoționale, crize de } \\
\text { afect, intelect de limtă, } \\
\text { substimulare }\end{array}$ & $\mathrm{M}$ & 5 ani și 3 luni & $\begin{array}{l}4 \text { ani și } 1 \\
\text { lună }\end{array}$ & 78 \\
\hline 5. & V.R. & $\begin{array}{l}\text { Retard psihic mediu, sindrom } \\
\text { hiperkinetic, crize de afect, } \\
\text { dificultăți de învățare }\end{array}$ & $\mathrm{F}$ & 7 ani și 2 luni & $\begin{array}{l}4 \text { ani și } 8 \\
\text { luni }\end{array}$ & 65 \\
\hline
\end{tabular}

Tab. 1 Tabel cu datele elevilor incluși în program

Privind la Rezultatele obținute la Probele pentru cunoașterea vârstei psihologice a limbajului se observă că patru din cei cinci copii au o vârstă psihologică a limbajului sub 4 ani în timp ce unul dintre copii are o vârstă psihologică de 1 an și 10 luni. Există diferențe în ce privește vârsta cronologică și vârsta psihologică a limbajului și, comparând datele de mai sus se poate concluziona că există diferențe inclusiv între vârsta mentală și vârsta psihologică a limbajului.

Probelor pentru cunoașterea vârstei psihologice a limbajului( A. Descouders)

\begin{tabular}{llll}
\hline \hline $\begin{array}{l}\text { Nr. } \\
\text { crt. }\end{array}$ & $\begin{array}{l}\text { Nume și } \\
\text { prenume }\end{array}$ & $\begin{array}{l}\text { Vârsta } \\
\text { cronologică }\end{array}$ & $\begin{array}{l}\text { Vârsta } \\
\text { psihologică } \\
\text { de } \\
\text { dezvoltare } \\
\text { a limbajului }\end{array}$ \\
\hline \hline 1. & B.A.A. & 8 ani & $\begin{array}{l}\text { 3 ani și 6 } \\
\text { luni }\end{array}$ \\
\hline 2. & V.L. & $\begin{array}{l}7 \text { ani și 10 } \\
\text { luni }\end{array}$ & $\begin{array}{l}\text { 3 ani și 11 } \\
\text { luni }\end{array}$ \\
\hline 3. & L.A. & $\begin{array}{l}\text { 4 ani și } 5 \\
\text { luni }\end{array}$ & $\begin{array}{l}\text { 1 an și 10 } \\
\text { luni }\end{array}$ \\
\hline 4. & B.B.I. & $\begin{array}{l}5 \text { ani și 3 } \\
\text { luni }\end{array}$ & $\begin{array}{l}\text { 3 ani și 2 } \\
\text { luni }\end{array}$ \\
\hline 5. & V.R. & $\begin{array}{l}7 \text { ani și 2 } \\
\text { luni }\end{array}$ & $\begin{array}{l}\text { 3 ani și 2 } \\
\text { luni }\end{array}$ \\
\hline \hline
\end{tabular}

Tab.2 Tabel cu Vârsta psihologică a limbajului obținută în urma aplicării

Evaluare competențelor morfologice s-a realizat prin "Proba de Evaluare a Abilităților Morfologice în Limba Română. Aplicaţii psiholingvistice" (PEAMLR). În următorul tabel putem observa rezultatele obținute de copii la această probă.

\begin{tabular}{llll}
\hline Nr.crt. & $\begin{array}{l}\text { Nume și } \\
\text { prenume }\end{array}$ & IQ & $\begin{array}{l}\text { Rezulate } \\
\text { obținute la } \\
\text { PEAMLR }\end{array}$ \\
\hline \hline $\mathbf{1 .}$ & B.A.A. & 52 & 46 \\
\hline 2. & V.L. & 64 & 39 \\
\hline 3. & L.A. & 64 & 36 \\
\hline 4. & B.B.I. & 78 & 43 \\
\hline
\end{tabular}




\begin{tabular}{cccc}
\hline \hline 5. & V.R. & 65 & 45 \\
\hline \multicolumn{4}{c}{ Tab 3} \\
Rezultate obținute de copii la \\
PEAMLR
\end{tabular}

Comparând rezultatele obținute de copii cu etalonul orientativ observăm că unul dintre aceștia se încadrează în intervalul de percentile $5-8$, iar 4 obțin rezultate care se încadrează în intervalul de percentile 3-6. Aceste rezultate sunt influențate nu doar de capacitatea intelectuală a copilului sau de gradul de dizabilitate intelectuală ci și de volumul vocabularul de care dispune copilul, nivelul lexical și capacitatea de comprehensiune verbală.

Implementarea și surprinderea efectului programului de intervenție multidimensionat

Pentru a surprinde evoluția și nivelul de achiziție a cuvintelor propuse pentru $\mathrm{T}^{50}$, s-a întocmit pentru fiecare copil câte un tabel privind profilul de achiziție a cuvintelor (Tab.4). Cuvintele care au fost pronunțate corect, sau au fost în curs de modelare, au fost prezentate părinților și cadrelor didactice de la clasă pentru ca să se extindă utilizarea lor corectă și în alte medii decât cabinetul.

\begin{tabular}{|c|c|c|c|c|}
\hline $\begin{array}{l}\text { Nr. } \\
\text { crt. }\end{array}$ & $\begin{array}{l}\text { Cuvinte } \\
\text { nou } \\
\text { abordate }\end{array}$ & $\begin{array}{l}\text { Cuvinte } \\
\text { însușite }\end{array}$ & $\begin{array}{l}\text { Cuvinte } \\
\text { în curs } \\
\text { de } \\
\text { modelare }\end{array}$ & Observații \\
\hline
\end{tabular}

Tab. 4 Model de tabel privind profilul de achiziție a cuvintelor pentru $T^{50}$

Analizând profilurile de achiziție a cuvintelor a fiecărui copil și observând datele din tabel, se poate spune că aceștia reușeșc să își însușească între 70 și $90 \%$ din cuvintele parcurse.

\begin{tabular}{llllll}
\hline \hline N & Numel & Num & Num & Numă & Proce \\
r. & e și & ăr de & ăr de & r de & ntaj \\
\hline
\end{tabular}

\begin{tabular}{llllll}
\hline \hline $\begin{array}{l}\text { cr } \\
\text { t. }\end{array}$ & $\begin{array}{l}\text { prenu } \\
\text { mele }\end{array}$ & $\begin{array}{l}\text { cuvin } \\
\text { te } \\
\text { parcu } \\
\text { rse }\end{array}$ & $\begin{array}{l}\text { cuvin } \\
\text { învăț } \\
\text { ate }\end{array}$ & $\begin{array}{l}\text { cuvint } \\
\text { e în } \\
\text { curs } \\
\text { de } \\
\text { model } \\
\text { are }\end{array}$ \\
& & & & & \\
\hline 1. & B.A.A. & 35 & 29 & 6 & $\begin{array}{l}82,85 \\
\%\end{array}$ \\
\hline 2. & V.L. & 35 & 27 & 8 & $\begin{array}{l}77,14 \\
\%\end{array}$ \\
\hline 3. & L.A. & 30 & 21 & 9 & $70 \%$ \\
\hline 4. & B.B.I. & 30 & 27 & 3 & $90 \%$ \\
\hline 5. & V.R. & 30 & 25 & 5 & $\begin{array}{l}83,33 \\
\%\end{array}$ \\
\hline \hline
\end{tabular}

Tab.5 Rezultate obținute la $T^{50}$

Ritmul de achiziție este lent, dar cu toate acestea procentul de însușire a cuvintelor din listă este destul de ridicat. Se mențin însă o parte din tulburările de pronunție marcate de omisiuni, înlocuiri sau dificultăți de pronunție a grupurilor consonantice Cea mai bună evoluție se observă la copiii cu dizabilitate intelectuală ușoară, deși procentele nu sunt cu mult mai mari față de ceilalți. Acest lucru se poate datora și faptului că în alegerea cuvintelor s-a ținut cont de particularitățile fiecărui copil în parte.

Pentru îmbunătățirea capacității de procesare fonologică a fost elaborat un set de exerciții ce urmărește formarea abilităților de manipulare a fonemelor în cadrul cuvântului și formarea capacității de analiză și sinteză fonetică la nivelul silabei și cuvântului. Exercițiile au fost adaptate după un set de itemi care testau abilitățile lingvistice ale elevilor preșcolari din Norvegia în cadrul unui studiu desfășurat de S.A.H. Lyster, A. O. Lerva, și C. Hulme (2016). Cele mai solicitante activități din programul de conștientizare fonologică au fost introduse cu atenție la jumătatea ședinței și au implicat identificarea fonemelor , 
numărarea fonemelor, identificarea sunetului initial, combinarea fonemelor numărarea fonemelor eliminarea fonemelor inițiale. S-au efectuat în completare exerciții de despărțire în silabe, cu numărarea acestora, exerciții de combinare a silabelor în cuvinte și a cuvintelor în propoziție.

Observațiile făcute pe parcursul întâlnirilor privind modul și capacitatea de realizare a sarcinilor din programul propus, relevă faptul că acești copii întâmpină dificultăți în primul rând în ce privesc cerințele și înțelegerea sarcinilor de lucru. A fost nevoie de explicații suplimentare în ce privește modul de desfășurare a sarcinii. S-a observat, de asemenea, dificultăți la sarcinile de eliminare a fonemelor inițiale, copiii reușind cu greu să identifice imaginea corespunzătoare cuvântului rămas în urma eliminării primului sunet. La sarcinile de numărare, copiii s-au descurcat puțin mai bine, mai ales că, cuvintele nu au avut o lungime foarte mare. La exercițiile privind identificarea sunetului inițial, capacitățile de realizare a sarcinilor au fost diferite la fiecare copil.

Pentru exercițiile de despărțire în silabe a cuvintelor, au fost utilizate mai întâi cuvinte simple, bisilabice astfel încât reușita și înțelegerea sarcinii să fie destul de bună. S-a trecut apoi și la cuvinte monosilabice sau cu mai multe silabe. Exercițiile au fost desfășurate atât oral, însoțite de bătăi din palme cât și exerciții pe suport hârtie cu cuvinte însoțite de imaginea corespunzătoare și care trebuiau despărțite în silabe având și sarcina de trasare sau încercuire a numărului de silabe corespunzător. Pe parcursul activităților s-a observat că reușita sarcinii este mai mare în cazul cuvintelor bisilabice sau trisilabice în timp ce la cuvintele monosilabice sau cu mai multe silabe performanțele sunt mai scăzute.

Pentru dezvoltarea competențelor morfologice a fost elaborat un set de exerciții care a urmărit în principal dezvoltarea următoarelor categorii morfologice: substantiv număr (sg./pl.); pronume gen/ număr; numeral cardinal; numeral ordinal; prepoziţii simple. În alegerea materialului lingvistic s-a urmărit introducerea cuvintelor nou învățate prin tehnica $\mathrm{T}^{50}$. S-au folosit imagini însoțite de cerința de a identifica imaginea corespunzătoare enunțului, cum ar fi: ,Leul este în cușcă.”; ,În coș sunt mere.” ; ,Trei copii se joacă.”, „, Al treilea balon este albastru.", Ei aleargă.; , Ochelarii sunt pe carte."

Alte activități, menite să vină în sprijinul învățării, au fost jocuri de genul ,, Eu spun una, tu spui mai multe" sau găsirea unui adjectiv potrivit pentru un substantiv sau verb dat. De asemenea, copiii au fost implicați în diverse sarcini și activități pentru însușirea conceptului de numerație și de recunoaștere a numeralelor ordinale. Aceste sarcini s-au dovedit a fi destul de dificile pentru copii, fiind însoțite de multe explicații și făcându-se paralele la alte exemple care vizau obiectele familiare sau din jurul copilului pentru a putea fi înțeleasă sarcina. În acest sens au fost folosite materiale concrete pentru a exemplifica și a înțelege numărul sau ordinea. Se mențin însă dificultăți la următoarele categorii: verb- în special modul verbului, adjectiv-grade de comparație, 
adeverbe, locuțiuni adverbiale, prepoziții compuse, morfeme suprasegmentaele, morfeme prin care se materializează categoria animat/inanimat.

Concluzionând cele de mai sus, putem afirma că la acești copii capacitatea de asimilare a cuvintelor în vocabular prin Tehnica listei celor 50 de cuvinte $-\mathrm{T}^{50}$ se manifestă în limite acceptabile, majoritatea copiilor reușind să își însușească o bună parte din cuvintele parcurse. De asemenea, o parte din aceste cuvinte au fost transferate din vocabularul pasiv în cel activ prin formularea de enunțuri, realizându-se astfel extinderea semnificației și sensului cuvântului în situații de vorbire, creând premisele extinderii și perfecționării lexicului. Putem astfel afirma că se verifică una din ipotezele noastre, cum că există o relație între utilizarea $T^{50}$ și dezvoltarea abilităților lexico-semantice.

Pe parcursul intervenției, s-a observat că acei copii care au stăpânit mai bine cuvintele nou învățate și care au reușit să le transpună mai repede în vocabularul activ, au reușit să rezolve mai bine și sarcinile care antrenează abilitățile morfologice. Aceștia au reușit să rezolve mai bine exercițiile de antrenare a acordului substantivului cu numărul sau antrenarea numeralului cardinal când sarcina era de identificare a imaginii corespunzătoare enunțului. S-a putut observa că extinderea numărului unităților lexicosemantice din vocabularul activ și pasiv și dezvoltarea abilităților de utilizare a unităților lexicosemantice, în acord cu conținuturile acestora au condus la performanțe mai bune în ce privește antrenarea componentelor morfologice.
Se poate astfel concluziona că există relații între dezvoltarea abilităților lexico-semantice și conturarea morfologică în contextul întârzierii în dezvoltare la copiii cu dizabilitate intelectuală. Totuși, nivelul de dezvoltare intelectuală influențează structura limbajului, iar utilizarea cuvintelor și a propozițiilor precum și înțelegerea semnificației lor depind de dezvoltarea cognitivă. Inteligibilitatea vorbirii rămâne încă afectată datorită erorilor articulatorii caracterizate de omisiuni, substituiri, reducerea grupurilor consonantice sau simplificarea fonemelor. De asemenea s-a observat că acești copii recurg frecvent la mecanismul imitației, la modelul de acțiune anterior, fără să supună analizei contextul prezentat. De aceea, a fost nevoie să fie adesea îndemnați și susținuți să se gândească mai întâi la conținutul sarcinii și apoi să ofere răspunsul.

\section{Concluzii}

Recuperarea întârzierii în dezvoltarea limbajului la acești copii nu este una spectaculoasă, ci se realizează cu pași mici și anevoioși iar aceasta și datorită tabloului simptomatologic pe care îl prezintă. Tulburările de atenție, tulburările emoționale, crizele de afect interferează negativ cu intervenția terapeutică. De altfel, exercițiile sunt foarte obositoare pentru copii și necesită alternarea acestora astfel încât să evităm posibile comportamente negativiste sau chiar agresive.

Până în prezent metodele și tehnicile folosite în acest studiu au adus rezultate pozitive în ceea ce privește dezvoltarea vocabularului și a laturii lexico- 
semnatice precum și dezvoltarea anumitor categorii morfemice. Totuși, pentru configurarea unei competențe de comunicare funcționale la copiii cu dizabilitate este nevoie de o perioadă de intervenție mult mai lungă, realizată în paralel cu activități de stimulare cognitivă. Chiar și în acest caz este posibil ca unii copii să râmână sub nivelul vârstei cronologice sau mentale în ceea ce privește achiziția limbajului.

\section{Bibliografie}

Avramescu, M. D., (2007). Defectologie și logopedie, Ediţia a 3-a, București: Editura Fundaţiei România de Mâine;

Bodea-Hațegan, C., (2016). LogopediaTerapia tulburărilor de limbaj. Structuri deschise, București: editura Trei;

Bodea Hațegan, C., (2014). Probă de evaluare a abilităților morfologice în limba română. Aplicații psiholingvistice, vol.III, Cluj- Napoca, edit.Argonaut, e-book;

Burlea, G., (2007). Tulburările limbajului scris-citit, București: Editura Polirom;

Law, J., Garrett, Z., Nye, C. (2005). Speech and Language Therapy Interventions for Children with Primary Speech and Language Delay or Disorder, The Campbell Collaboration; https://onlinelibrary.wiley.com/doi/p df/10.4073/csr.2005.5;

Lyster, Solveig-Alma \& Lervåg, Arne \& Hulme, Charles. (2016). Preschool morphological training produces long-term improvements in reading comprehension. Reading and Writing; https://www.ncbi.nlm.nih.gov/pmc/a rticles/PMC4875956/;

Preda, V., (2007). Elemente de psihopedagogie speciala, ClujNapoca, editura Eikon;

Slama-Cazacu, T., (1999).

Psiholingvistica, o știinţă a comunicării, București, Editura All

'.Profesor psihopedagog la Centrul S,colar pentru Educație Incluzivă „Speranța”, Zalău.

E-mail: nina mosneag@yahoo.com 


\title{
Resursele materiale și virtuale utilizate în terapia tulburărilor de limbaj. Studiu descriptiv bazat pe focus-grup
}

\author{
Carolina BODEA HAȚEGAN ${ }^{1}$, Dorina TALAȘ², Raluca TRIFU³
}

\begin{abstract}
This article describes a research study developed during the webinar organized in order to celebrate 6 th of March as European Day of Speech \& Language Therapy. In this research participated Romanian SLTSS (N=150). The research was based on the following objectives: to identify the typology of the present used resources in the Romanian SLT field; to implement the Padlet as a tool for collecting and sharing data and to identify the area of resources that has to be developed. Results demonstrated that $S L T$ s mainly use virtual resources $(V R=106)$ in their present work and that material resources that can be used online is the less detailed and mentioned category $(M R V=17)$. The third category of resources is the category of material resources (MR), those that are to be used mainly during face-to-face SLT therapy. This category is represented by a relatively low number of units, compared with VR $(M R=61)$. Regarding the use of Padlet, we consider that this focused-group based research was enhanced with success, participants in the research, even if they were a numerous group, and the research was developed online, had the chance to express their points of view, without difficulties.
\end{abstract}

Keywords: Padlet, focus-group, SLT, resources, virtual resources, material resources

\section{Introducere}

Actualizare constantă a resurselor necesare evaluării și intervenției în domeniul terapiei tulburărilor de limbaj și comunicare constituie o preocupare intrinsecă a specialiștilor care activează în acest domeniu, dar și a profesioniștilor din domenii conexe. Preocuparea pentru accesul unui număr cât mai larg de beneficiari către serviciile de logopedie sau terapia tulburărilor de limbaj prin oferirea de terapii în mediul online este o preocupare mai veche, cu studii începute încă din anii 2000 (Edwards et al., 2012; Harrison, 2011; Polovoy, 2008).Pentru o perioadă implicațiile au fost destul de reduse și uzul lor era marcat mai mult de specificul local sau a unui areal geografic, fără o distribuție consistentă în domeniu, deși posibilele beneficii erau discutate (Cohn, 2012; Theodoros, 2011; Todd Houston et al., 2012). Un studiu realizat de grupul de lucru WP- Telepractice în
SLT, din cadrul CPLOL (Trifu et al., 2018) a indicat faptul că telepractica este folosită într-o mică parte în spațiul european și că un un număr mic de participanți la studiu declarau că folosesc în mod personal telepractica. Dar manifestau interes pentru a folosi această modalitate de adresare a beneficiarilor în viitor. Mai mult acest serviciu era decontat doar într-o mică măsură de sistemul de sănătate. În ceea ce privea tipul de tehnologii sau de platforme utilizate, skype-ul este utilizat pe scară largă pentru sesiunile de telepractică, urmat de programe speciale pentru telepractică în procent de 5,04\% . Copiii și adulții beneficiază în mod egal de sesiuni de telepractică, care sunt utilizate cu pacienții $(25 \%)$ sau cu aparținătorii (11\%). Iar $43 \%$ participanții consideră că intervenția prin telepractică poate fi la fel de eficientă ca și sesiunile față în față. Rezultatele studiului (Trifu et al., 2018) insistau asupra posibilităților largi pe 
care apelul la tehnologiile informației le poate avea în oferirea de servicii specializate în terapia tulburărilor de limbaj și de comunicare și întrevedeau posibilele schimbări care s-ar putea produce în domeniul SLT, dar observa și reticența pe care terapeuții de limbaj o aveau față de uzul noilor tehnologii și posibilele dificultăți de ordin juridic, cele de reglementare a procedurilor sau de asigurarea securității, confidențialității și a datelor în mediul online. Concluzia grupului de lucru era că terapia online în SLT / SLP este benefică în caz de distanța sau acces redus la specialiștii în anumite domenii, dar provocările sunt mari, iar formarea și resursele speciale sunt necesare pentru ședințele de terapie.

Anul 2020 a adus schimbări marcante în acest domeniu, modificări pe care studiile anterioare asupra terapiei limbajului și educației online nu le puteau prevede sau nu le puteau aștepta atât de rapid. Modificările au fost posibile de activarea a două evenimente marcante: pe de o parte se impune a fi adusă în discuție pandemia Covid - 19 determinată de virusul SARS-Cov2 și declararea stării de urgență și de alertă la nivel mondial, iar pe de altă parte,

Tabel 1 - Distribuția estimativă a accesului la internet în 2021. Conform https://www.internetworldstats.com/

\begin{tabular}{|c|c|c|c|c|c|c|}
\hline Continente & $\begin{array}{l}\text { Populație } \\
\text { (Estimare } \\
\text { 2021) }\end{array}$ & $\begin{array}{l}\text { Populația } \\
\text { lumii \% }\end{array}$ & $\begin{array}{l}\text { Utilizatori } \\
\text { internet } 31 \\
\text { Dec } 2020\end{array}$ & $\begin{array}{l}\text { Procent în } \\
\text { populație } \\
\text { (\% Pop.) }\end{array}$ & $\begin{array}{l}\text { Creșterea } \\
\text { în } \\
\text { intervalul } \\
\mathbf{2 0 0 0 - 2 0 2 1}\end{array}$ & $\begin{array}{l}\text { Distribuți } \\
\text { a } \\
\text { accesului } \\
\text { la internet } \\
\text { la nivel } \\
\text { mondial } \\
\%\end{array}$ \\
\hline Africa & $1,373,486,514$ & $17.4 \%$ & $634,863,323$ & $46.2 \%$ & $13,963 \%$ & $12.5 \%$ \\
\hline Asia & $4,327,333,821$ & $54.9 \%$ & $2,707,088,121$ & $62.6 \%$ & $2,268 \%$ & $53.1 \%$ \\
\hline Europa & $835,817,917$ & $10.6 \%$ & $728,332,705$ & $87.1 \%$ & $593 \%$ & $14.3 \%$ \\
\hline
\end{tabular}

dinamica creșterii exponențiale a accesului la serviciile digitale și de internet. Statistica uzului accesului la internet la nivelul anului 2021, față de 2020, indică o creștere substanțială a accesului și utilizării internetului, pentru unele regiuni, cum este spațiul European, observându-se o creștere procentuală și de $593 \%$, un procent greu de imaginat în anii precedenți. Conform datelor statistice (Europe Internet Use and Population Statistics, 2020; WIS, 2020) în anul 2011 exista un număr de 2,1 miliarde de utilizatori de internet la nivel mondial și aproximativ $58 \%$ au raportat că au făcut căutări legate de informarea și accesul la servicii medicale și auxiliar medicale. În 2020, numărul utilizatorilor de internet a crescut și nevoia de ajutor prin intermediul internetului a crescut în mod proporțional, substanțial. Din punct de vedere statistic accesul la internet va facilita implicit și accesul către profesioniștii și specialiștii din domeniul terapiei tulburărilor de limbaj, prin apel la serviciile de terapie online. Conform estimărilor actuale (WIS, 2020), situația accesului la internet, distribuit pe regiuni geografice se configurează conform datelor prezentate în tabelul numărul 1.

\section{a}




\begin{tabular}{|c|c|c|c|c|c|c|}
\hline $\begin{array}{l}\text { America } \\
\text { latină / } \\
\text { Caraibe }\end{array}$ & $659,743,522$ & $8.4 \%$ & $477,848,538$ & $72.4 \%$ & $2,544 \%$ & $9.4 \%$ \\
\hline $\begin{array}{l}\text { Orientul } \\
\text { Mijlociu }\end{array}$ & $265,587,661$ & $3.4 \%$ & $188,132,198$ & $70.8 \%$ & $5,627 \%$ & $3.7 \%$ \\
\hline $\begin{array}{l}\text { America de } \\
\text { Nord }\end{array}$ & $370,322,393$ & $4.7 \%$ & $332,912,495$ & $89.9 \%$ & $208 \%$ & $6.5 \%$ \\
\hline $\begin{array}{l}\text { Oceania / } \\
\text { Australia }\end{array}$ & $43,473,756$ & $0.6 \%$ & $29,286,392$ & $67.4 \%$ & $284 \%$ & $0.6 \%$ \\
\hline $\begin{array}{l}\text { Număr } \\
\text { total la } \\
\text { nivel } \\
\text { mondial } \\
\end{array}$ & $7,875,765,584$ & $100.0 \%$ & $5,098,463,772$ & $64.7 \%$ & $1,312 \%$ & $100.0 \%$ \\
\hline
\end{tabular}

Adresabilitatea în terapia și educația online în anul 2020 a fost diversă, iar diagnostice care erau considerate a fi imposibil de adresat prin terapie online, au constituit în final provocări care și-au găsit rezolvarea. Într-un studiu (Alqudah et al., 2021) care viza impactul Covid- 19 asupra persoanelor protezate auditiv se atrăgea atenția asupra dificultății de apelare, în varianta clasică, a terapeuților de limbaj și implicit nevoia de utilizare a unor modalități alternative de acces a serviciilor logopedice. Un alt studiu (Becker \& Gillespie, 2021) semnaliza beneficiile și limitările telepracticii atunci când adresabilitatea este în tulburările de voce. Alți autori (Pamplona \& Ysunza, 2020) s-au concentrat pe dificultățile apărute în telepractica logopedică în condițiile diagnosticului de despicătură palatină, dar și a implicațiilor telepracticii în recuperarea afaziei (Finch et al., 2020; Hall et al., 2013). Dificultatea majoră menționată în literatura a fost cea care a presupus oferirea de terapii on line în condițiile unui diagnostic de tulburare de spectru autist (Narzisi, 2020; Samadi et al., 2020), deși demersuri pentru facilitarea accesului la resurse logopedice prin terapia online, mai ales în contextul limitărilor impuse de spațiul geografic au fost demarate încă din 2010 (Boisvert et al., 2010; Parsons et al., 2017).

O relevanță aparte se pare a avea un alt studiu (Lam et al., 2021) care s-a concentrat pe percepția serviciilor de terapie logopedică online, prin prisma aprecierilor venite din partea părinților și a elevilor beneficiari. Studiul indica faptul că, deși eficacitatea terapiilor logopedice online a fost extrem de apreciată de către părinți ( $95 \%$ CI 3,303,66) și elevi (95\% CI 3,21-3,76), ambele grupuri credeau că terapia logopedică online era mai puțin eficientă decât terapia față în față (părinți: 95\% CI 2,142,52; elevi: $95 \%$ CI 2,08-2,65). Mai mult, părinții au preferat practicile la fața locului decât terapia online $(95 \%$ 2,042,43 ), în timp ce elevii nu au preferat un mod de practică față de celălalt $(95 \%$ 2,74-3,41). O asociere semnificativă între eficacitatea terapiei online și o preferință pentru serviciile de terapie online de a fost găsită numai în rândul elevilor ( $\tau=$ .43, $\mathrm{P}<$ <.001), nu în rândul părinților ( $\tau=$ .07; $\mathrm{P}=.44$ ). Studiul (Lam et al., 2021) sublinia faptul că deși terapia logopedică 
on-line este o alternativă acceptabilă de furnizare a serviciilor logopedice, terapeuții și părinții trebuie să joace un rol mai proactiv în serviciile de terapie online pentru a facilita comunicarea eficientă între profesioniști și beneficiari. În mod similar, un alt studiu (Fong et al., 2021) atrăgea atenția asupra dificultăților iscate de adaptare rapidă la oferirea de servicii terapeutice online, comparativ cu situația în care există deja o experiență în acest sens.

Percepția specialiștilor asupra oferirii de servicii de terapie online este la fel de importantă. Spre exemplu terapeuții din Croația (Kraljević et al., 2020), majoritatea angajați în practica clinică și privată au oferit servici de terapie logopedică online, dar s-au confruntat și cu refuzul beneficiarilor, refuz marcat de lipsa echipamentului, insuficienta independență și neîncrederea în eficacitatea telepracticii. Deși doar 3\% dintre SLP-uri au dobândit unele cunoștințe formale de telepractică înainte de pandemie, peste $70 \%$ și-au exprimat satisfacția față de terapia online, deoarece le-a permis să ofere servicii clinice în condiții excepționale. Într-o altă parte a lumii, într-un studiu similar (Kim et al., 2020) care viza percepția specialiștilor în terapia tulburărilor de limbaj asupra terapiei online, s-a evidențiat faptul că majoritatea terapeuților erau dispuși să participe la programe de educație, dar că doar o mică parte au utilizat aceste tehnologii înainte de pandemie. Scepticismul față de terapia online a venit din partea terapeuților cu mai multă experiență clinică și tot ei au avut tendința să creadă că utilizarea telepracticii depinde de caracteristicile clienților, atât în privința patologiei cât și a caracteristicilor comportamentale și cognitive. Unele tulburări precum dificultățile de lexie și fluență au fost considerate potrivite pentru terapia online, iar tulburarea deglutiției și dizabilitatea auditivă au fost considerate inadecvate pentru mediul online.

Completarea cu informații privind apelul la tehnologiile online, înțelegerea și dimensiunea practicii online, dar și documentarea comunicării în spațiul virtual în diverse arealuri geografice permite obținerea unui profil relevant în configurarea viitoare a serviciilor educaționale și terapeutice online

Contextul pandemic atrage după sine, pe lângă schimbările din abordarea demersului terapeutic prin utilizarea pe scară largă a terapiei online, și multe schimbări la nivelul resurselor utilizate. Astfel că, pe lângă că au apărut o serie de posibilități virtuale de creare de noi resurse, precum și noi direcții de utilizare a resurselor material preexistente. Talaș (2015) propune analizarea fiecărui caz în parte, pentru a identifica atât beneficiile cât și dificultățile care pot să apară atunci când se recomandă terapia online.

Varietatea și bogăția materialelor logopedice este de subliniat în acest moment, când, forțați de împrejurări mai puțin favorabile, terapeuții limbajului au fost nevoiți să creeze materiale prin care să găsească soluții în vederea continuării demersului terapeutic, absolut necesar beneficiarilor. Bodea Hațegan C și Talaș D. (2020) propun un set de resurse online care pot fi utilizate atât de către terapuți cât și de către carele didactice în activitatea pe care o desfășoară online. 


\section{Obiective}

$\mathrm{Cu}$ ocazia webinarului organizat pentru a marca Ziua Internațională a Terapiei Limbajului, webinar intitulat Telepractica și tehnologiile digitale în terapia tulburărilor de limbaj și de vorbire s-a derulat un studiu de colectare de date cu privire la resursele utilizate de terapeuți.

Obiectivele studiului au fost:

1. identificarea resurselor cele mai frecvent utilizate de terapeuții limbajului în contextul actual pandemic,

2. implementarea aplicației Padlet, ca instrument ce permite colectarea integrată a răspunsurilor la nivelul focusgrupului.

3. identificarea ariilor din domeniul terapiei limbajului care au nevoie de noi resurse și materiale.

\section{Participanții la studiu}

Participanții la studiu au fost în număr de $150 \quad(\mathrm{~N}=150)$, toți participanții sunt membri ai Asociației Specialiștilor în Terapia Tulburărilor de Limbaj din România - ASTTLR și au preocupări în sfera terapiei limbajului, atât în mediul privat, cât și cel de stat.

\section{Instrumente}

Instrumente utilizate în colectarea datelor și procedura de lucru

Padlet - este o platformă care permite utilizatorilor care au acces la linkul creat de un utilizator să scrie, să adauge un hiperlink, o fotografie, sau un document. Toate persoanele care accesează acest link văd în timp real tot ce se scrie sau se postează. (https://padlet.com)
Platforma ZOOM cu activarea opțiunii "breakout rooms" a permis crearea grupelor de lucru și realizarea focus grupului..

Focus grupul este o modalitate de studiu derulată la nivelul unui grup (în cazul de față un grup format din specialiști în terapia tulburărilor de limbaj) prin care se vizează identificarea unor aspecte particulare legate de o problematică centrală (problematica sstudiată este cea resurselor utilizate în mod recurent, în zilele noastre în terapia limbajului) (Krueger R.A., Casey M.A, 2005).

S-a optat pentru utilizarea focusgrupului pentru că se consideră că avantajul major al grupului de specialiști, care împreună aduc în prim plan aspecte nevralgice ale muncii zilnice pe care o derulează și care împreună pot găsi soluții pertinente, este spre deosebire de a interviului, că soluțiile identificate sunt născute din interacțiunea membrilor grupului.

Deoarece un focus-grup nu poate $\mathrm{fi}$ realizat cu un număr mare de participanți, specialiștii în terapia limbajului participanți la studiu au fost împărțiți, în mod aleatoriu, în mai multe grupuri, 25 echipe a câte 6 membri în fiecare echipă. Fiecare grup de lucru trebuie să insereze în Padlet resursele utilizate în demersul terapeutic. Timpul de lucru a fost de 20 minute.

\section{Rezultate obținute}

Datele obținute sunt contabilizate la nivelul link-ului

https://padlet.com/cursuriasttlr/n804dx kdo6y 4 sn 49 


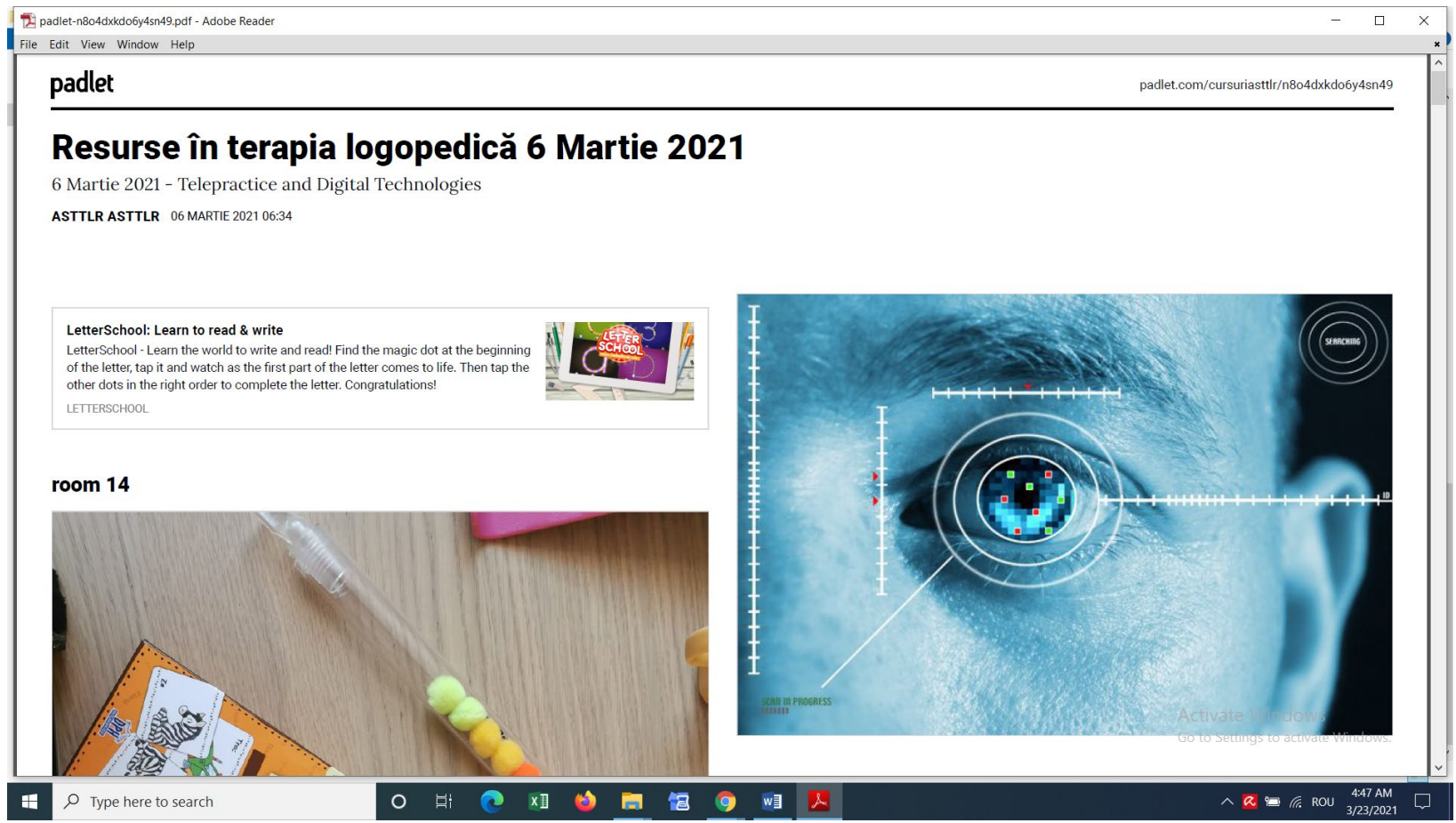

Fig 1. Selecție din rezultatele obținute

\section{Rezultate obținute}

Resursele utilizate în terapia logopedică, descrise și menționate în Padlet de participanții la studiu pot fi grupate în 3 categorii:

1. resurse materiale, clasice care presupun manipulare și care trebuie utilizate de copil sau părinte, ele pot fi utilizate mai concret în contextul terapiei față în față, în online putând fi transpuse doar cu ajutorul părintelui.

Tabel 2. Tipuri de resurse utilizate în terapia logopedică actuală

\begin{tabular}{ll}
\hline \hline Resursele utilizate & Unități menționate \\
\hline Resurse materiale (RM) & 61 \\
\hline $\begin{array}{l}\text { Resurse materiale care pot fi transpuse și în } \\
\text { mediul online (RMV) }\end{array}$ & 17 \\
\hline Resurse virtuale (RV) & 106 \\
\hline
\end{tabular}

Se poate constata faptul că datele polarizează înspre utilizarea resurselor virtuale, digitale, numărul acestora fiind
2. resurse materiale clasice care pot fi transpuse/transferate și în mediul online,

3. resurse virtuale (aplicații, platforme digitale, softuri etc.).

În tabelul de mai jos ilustrăm și sub aspect cantitativ modul în care cele trei tipuri de resurse sunt menționate a fi utilizate în demersul terapeutuc actual, de participanții la studiu: aproape dublu față de cel al resurselor materiale. 


\section{Discuții}

În continuare se analizează fiecare categorie de resurse delimitată de participanții la studiu și se ilustrează cu exemple colectate.

\section{Resurse materiale}

Resursele materiale existente pot $\mathrm{fi}$ utilizate în variante terapiei online mai dificil. Ele au fost create pentru a fi utilizată în demersul terapeutic față în față. Utilizarea acestor resurse în mediul online, terapeutul având rolul de ghidare și îndrumare, se poate realiza doar dacă se solicită părinților copiilor/aparținătorilor persoanelor aflate în demersul terapeutic să achiziționeze aceste materiale. S-ar putea spune că această situație ar atrage costuri mai mari pentru părinte. În fapt, chiar și în contextul terapiei față-în-față anumite produse erau achiziționate de către părinte tocmai din motive de siguranță și igienă, producătorii lor recomandând utilizarea individuală.

Dintre aceste produse menționate de terapeuții limbajului participanți la studiu, care se utilizează frecvent în demersul terapeutic logopedic și pe care părintele le poate achiziționa și utiliza sub ghidarea online a terapeutului aducem în prim plan:

\section{Flow-Ball}

Acesta este un dispozitiv neelectronic, ușor de manipulate și utilizat, dar care are $\mathrm{o}$ valoare crescută în demersul therapeutic pentru a facilita prelungirea expirului, cu scopul pregătirii unei respirații verbale funcționale. De asemenea, Flow-Ball se poate utiliza și pentru creșterea volumului respirator, a tonifierii musculare implicate în actul respirator, dar și pentru a relaxa și tensiona musculatura implicată în actul fono-articulator.

Lã, Wistbacka, Andrade, Granqvist (2017) au subliniat valoare acestui tip de instrumente în educarea respirației cu scopul modelării vocii, subliniind că biofeedback-ul vizual care este asigurat de urmărirea mingii ce trebui să fie propulsată în aer, alături de antrenarea respirației prin tub (Smith, Titze, 2017), conduce la îmbunătățirea clară a capacității de expir, iar abilitatea de prelungire a expirului este absolut necesară în actul fonator.

Flow-Ball se poate utiliza de la vârste foarte mici, chiar de la vârsta de 1 an și are valoare terapeutică și la adulți.

\section{Breath-Builder}

Acesta este un dispozitiv neelectronic, ușor de utilizat, care poate fi utilizat foarte eficient în vederea creșterii volumului respirator și antrenării capacității respiratorii, a tensionării musculare diafragmatice, a diferențierii inspirului de expir și a respirației orale de cea nazale .

Breath-Builder nu poate fi utilizat în activitățile cu copiii antepreșcolari. Valoarea lui terapeutucă este mai crescută în activitățile pentru școlari, adolescenți și adulți. Este utilizat și studiat pe scară largă și în contextul modelării respirației la cântăreți, unde beneficiile acestuia sunt studiate (Mazon, 2009).

\section{Solo-Phone Whisper}

Este un dispozitiv neelectronic, ușor de pus în practică chiar și de către părinte și copil. Acesta constă într-o cordeluță care 
se plasează pe cutia craniană și se fixează printr-un punct la nivelul urechii. De asemenea, dispozitivul are și o parte care ajută în captarea sunetelor emise. Practic, acest dispozitiv valorifică conducția osoasă, potențând autoaudiția și facilitează: creșterea abilităților perceptiv-auditive, dezvoltarea abilităților atenționale, creșterea abilităților de diferențiere și discriminare auditivă. Dispozitivul poate fi utilizat cu succes chiar și terapia copiilor cu dizabilități sau tulburări (ADHD, TSA, dizabilitate intelectuală sau tulburări de dezvoltare). În contextul terapiei limbajului acest dispozitv are o valoare crescută în antrenarea abilităților de procesare auditivă, în etapa logopedică de formare a preachizițiilor limbajului.

\section{$\underline{\text { Kit-ul TALK TOOLS }}$}

Acesta este constituit dintr-un bogat set de instrumente variate, obiecte, jucării menite să fie utilizate în vederea antrenării grupelor motorii oro-faciale. Kit-ul conține: Horn Kit (instrumente pentru antrenarea respirației), Straw Kit (paie de diferite forme și mărimi pentru antrenarea respirației, a musculaturii labiale și a vocii), Spinner și Toothies (un instrumentar care permite evaluarea sensibilității și, în același timp, antrenarea oro-motorie) și 2 seturi de instrumente pentru antrenarea maxilarelor, a abilităților masticatorii (Jaw Grading Bite Blocks). Kit-ul Talk Tools vine să deschidă perspectiva de abordare oro-motorie într-o altă paradigmă (Bahr, Rosenfeld-Johnson, 2010), cea a poziționării corecte a subcomponentelor aparatului fonoarticulator, nu a sublinierii importanței antrenării motorii a grupelor musculare, în contextul în care cercetările anterioare nu au putut aduce dovezi științifice în a susține antrenarea motorie oro-facială ca fiind valoroasă în corectarea tulburărilor de pronunție (Lof, Watson, 2008; Lass, Pannbacker, 20o8; McCauley, Strand, Lof, Schooling \& Frymark, 2009).

Varietatea instrumentelor, posibilitatea ca acestea să fie improvizate în casă de părinte, simplitatea unora dintre acestea subliniază încă o dată faptul că este important să cooptăm părintele, aparținătorii în acest demers al terapiei logopedice.

Cele patru instrumente materiale prezentate pot fi utilizate și în contextul reabilitării persoanei care a trecut printrun episod sever de infecție cu virusul pandemic SARS-CoV-2 (Ali Ismail, 2020). Ele pot fi utilizate fie demonstrându-i părintelui, aparținătorului sau chiar persoanei aflată în terapie cum se utilizează pe parcursul întâlnirilor online. De asemenea, pot fi utilizate prin modelare video și se poate constata că pe site-urile care comercializează aceste produse sunt o mulțime de înregistrări video cu exemplificări ale modului de utilizare a instrumentelor și explicațiile necesare.

\section{Resurse materiale faptice}

Resursele materiale faptice, concrete ce se foloseau în paradigma tradițională clasică, față-în-față pot fi transpuse în varianta terapeutică online fie prin:

- Scanare- dacă ne referim la utilizarea unor cărți cu fișe,

- Partajarea unor fișe tehnoredactate care în varianta de terapie față în față se lucrau după ce erau listate, iar online se lucrează prin împărtășirea 
lor prin intermediul platformelor online și completarea lor fie de către terapeut, fie de beneficiar, cu ajutorul funcției "Control la distanță".

- Arătarea lor prin intermediul camerei web - dacă e vorba de jucării, jocuri, obiecte concrete, machete, cartonașe etc.

-Utilizare/manipularea de către terapeut a unor materiale care nu pot fi angrenate în procesul terapeutic transpus online altfel, de exemplu puzzle-urile, cuburi, biluțe și capse utilizate în jocurile de tip mozaic.

Dintre aceste resurse participanții la studiu menționează: cărțile cu fișe logopedice, jocurile create pentru domeniul logopedic sub cupola "Jucării Vorbărețe", cartonașele de tip Montessori, cărțile de povești, puzzleurile, cartonașele ABCDELA- silabe, cuvinte monisilabice, cartonașele din jocul MIADE, cartonașele de la editura GAMA.

Este de menționat că deși numărul acestor menționări este cu mult mai mic, decât în cazul resurselor materiale sau a celor virtuale $(\mathrm{N}=17)$, acest aspect se datorează faptului că acestea sunt delimitate prin prisma categoriilor, nu prin primsa unor unități specifice, (de exemplu: categoria cărți cu fișe logopedice nu se detaliază cu exemple concrete).

\section{Resursele virtuale}

Resursele virtual elaborate, resursele care au fost elaborate online și care pot fi utilizate în demersul terapeutic online fie direct de către părinte sau de terapeut prin utilizarea unor platforme care permit rularea lor în mod interactiv.
Dintre aceste resurse pentru domeniul terapeutic logopedic din țară specific create și utilizate de respondenții la studiu sunt:

a.Site-ul https://cubulet.ro/- este un site care facilitează generarea de fișe de lucru pentru antrenarea fluenței în citire, dar și în calcul matematic. De asemenea, siteul conține și jocul Bingo Educațional. Acest site a fost gândit ca un generator de resurse educaționale deschise online.

b. Wordwall este o platformă foarte utilizată în vederea creării de resurse terapeutice, este la îndemâna oricărui terapeut care își deschide un cont sau chiar și fără a avea cont configurat. Platforma pune la dispoziția specialiștilor o serie de resurse deja create, dar oferă și posibilitatea de a-ți elabora și propriile resurse.

c. Liveworkheets este o platformă bogată în resurse create virtual și care pot fi utilizate în domeniul terapeutic logopedic, mai ales resurse care se adresează școlarilor și prin intermediul lor sunt abordate aspecte legate de formarea abilităților de scris-citit și calcul matematic.

d. Story Board That este un site care permite elaborarea online a unor scurte povestioare. Este un instrument care facilitează în special antrenarea abilităților lingvistice propoziționale și discursive, precum și formarea abilităților narative și a deprinderilor social-contextuale.

e. Word Eminus este o platformă educațională care permite evaluarea preachizițiilor limbajului, cu scopul configurării unui program de prevenție, încă din perioada ultimului an de 
grădiniță, a tulburărilor de învățare care pot surveni. Este creat respectând specificul limbii române prin intermediul proiectul TALK (2017-2019) (Bodea Hațegan, 2019).

Ultimul obiectiv al cercetării a fost identificarea subdomeniului logopedic în care au fost menționate resursele cele mai puține pentru a avea în vedere acest aspect în demersurile viitoare. În baza răspunsurilor oferite, subdomeniul cel mai puțin bogat în resurse a fost cel morfologic, aici au fost indicate doar 2 resurse, ceea ce deschide direcții pentru cercetări viitoare.

\section{Concluzii}

Acest focus-grup organizat pentru a surprinde specificul utilizării resurselor în domeniul terapiei logopedice a condus la delimitarea a trei categorii de resurse terapeutice: resursele materiale, resursele materiale care pot fi transpuse în mediul virtual și resursele virtuale. Răspunsurile terapeuților au polarizat spre detalierea și enumerarea resurselor virtuale, ceea ce este în concordanță cu vremurile pandemice pe care le traversăm și care, se pare că nu se vor încheia prea curând. Terapeuții limbajului sunt clar preocupați de identificarea și împărtășirea de resurse virtuale și au lăsat în plan secund resursele materiale clasice, iar transpunerea resurselor clasice în mediul online, se pare că este înlocuită cu tendința de a identifica și crea resurse direct cu scopul de a fi utilizate virtual.

Ca direcție viitoare de studiu și cercetare $\mathrm{s}$-a desprins subdomeniul morfologic al limbajului care are nevoie de mai multă atenție sub aspectul resurselor ce pot fi utilizate, atât la nivel receptiv, cât și expresiv, astfel asumarea nevoii de a crea resurse virtuale pe acest subdomeniu al limbajului se desprinde specific.

\section{Bibliografie:}

Ali Ismail, A. (2020). Online exercise rehabilitation to stable COPD patients during the second COVID wave: are physiotherapists able to help?. Advances in Rehabilitation, 34(4), 48-49. https://doi.org/10.5114/areh.2020.1015 92

Alqudah, S., Zaitoun, M., Alqudah, O., Alqudah, S., \& Alqudah, Z. (2021). Challenges facing users of hearing aids during the COVID-19 pandemic. International Journal of Audiology, 17 .

https://doi.org/10.1080/14992027.2021 .1872806

Bahr, D., Rosenfeld-Johnson,S. (2010). Treatment of children with Speech Oral Placement Disorders (OPDs): A Paradigm Emerges. Communication Disorders Quarterly, XX(X) 1-8.

Becker, D. R., \& Gillespie, A. I. (2021). In the Zoom Where It Happened: Telepractice and the Voice Clinic in 2020. Seminars in Speech and Language, $\quad 42(01), \quad 064-072$. https://doi.org/10.1055/s-00401722750

Bodea Hațegan, C. (2019). TALK Language and literacy curriculum for pre-schoolers and school-age children: a programme to improve inclusion, scholastic achievement and social well-being (TALKCHIL), în Revista Română de Terapia Tulburărilor de Limbaj și 
Comunicare-RRTTLC, V/2019, Nr. 1, ASTTLR, Cluj-Napoca, p.3-7, ISSN: 2457-9262 (indexed in Erih Plus, CEEOL, DOAJ ). DOI: 10.26744/rrttlc.2019.5.1.02

Bodea Hațegan, C., Talaș D. (2020) Ghid practic de organizare a activităților online. Presa Universitară Clujeană. http://www.editura.ubbcluj.ro/www/ ro/ebooks/domains.php?id=16

Boisvert, M., Lang, R., Andrianopoulos, M., \& Boscardin, M. L. (2010). Telepractice in the assessment and treatment of individuals with autism spectrum disorders: A systematic review. In Developmental Neurorehabilitation (Vol. 13, Issue 6, pp. 423-432). https://doi.org/10.3109/17518423.2010. 499889

Cohn, E. R. (2012). Tele-Ethics in Telepractice for Communication Disorders. Perspectives on Telepractice, 2(1), 3-15. https://doi.org/10.1044/tele2.1.3

Edwards, M., Stredler-Brown, A., \& Houston, K. T. (2012). Expanding Use of Telepractice in Speech-Language Pathology and Audiology.: EBSCOhost. The Volta Review, 112(3), 227-242.

http://web.a.ebscohost.com/ehost/p dfviewer/pdfviewer?vid=28\&sid=3fa2 3712-8835-4a49-9dade64be7f26113\%40sessionmgr40o1\&hid $=4114$

Europe Internet Use and Population Statistics. (2020). https://www.internetworldstats.com/ stats4.htm\#europe
Finch, E., Lethlean, J., Rose, T., Fleming, J., Theodoros, D., Cameron, A., Coleman, A., Copland, D., \& McPhail, S. M. (2020). Conversations between people with aphasia and speech pathology students via telepractice: A Phase II feasibility study. International Journal of Language and Communication Disorders, 55(1), 4358. https://doi.org/10.1111/1460$\underline{6984.12501}$

Fong, R., Tsai, C. F., \& Yiu, O. Y. (2021). The Implementation of Telepractice in Speech Language Pathology in Hong Kong during the COVID-19 Pandemic. Telemedicine and EHealth, 27(1), 30-38. https://doi.org/10.1089/tmj.2020.0223

Hall, N., Boisvert, M., \& Steele, R. (2013). Telepractice in the Assessment and Treatment of Individuals with Aphasia: A Systematic Review. International Journal of Telerehabilitation, $5(1)$. https://doi.org/10.5195/ijt.2013.6119

Harrison, D. (2011). Speech Language Clinicians Connect with Telepractice. The Journal. https://thejournal.com/articles/2011/ 02/02/speech-language-cliniciansconnect-with-telepractice.aspx

Kim, N. Y., Ha, J. W., Park, K. S., Lee, G. J., Park, S. N., \& Bae, Y. S. (2020). Perception of Korean SpeechLanguage Pathologists on Telepractice Service. Communication Sciences and Disorders, 25(4), 987997.

https://doi.org/10.12963/CSD.20776

Kraljević, J. K., Matić, A., \& Dokoza, K. P. (2020). Telepractice as a reaction to 
the COVID-19 crisis: Insights from croatian slp settings. International Journal of Telerehabilitation, 12(2), 93-104.

https://doi.org/10.5195/ijt.2020.6325

Krueger R.A., Casey M.A, (2005). Metoda focus-grup. Ghid practic pentru cercetarea aplicată, trad. Rom. Cristina Popa, Polirom, Iaşi (ediţie originală 2000, Sage Publications).

Lã, F., Wistbacka, G., Andrade, P. A., \& Granqvist, S. (2017). Real-Time Visual Feedback of Airflow in Voice Training: Aerodynamic Properties of Two Flow Ball Devices. Journal of Voice: official journal of the Voice Foundation, 31(3), 390.e1-390.e8. https://doi.org/10.1016/j.jvoice.2016.0 9.024

Lam, J. H. Y., Lee, S. M. K., \& Tong, X. (2021). Parents' and students' perceptions of telepractice services for speech-language therapy during the COVID-19 pandemic: Survey study. JMIR Pediatrics and Parenting, 4(1). https://doi.org/10.2196/2567 5

Lass, N. J. \& Pannbacker, M. (2008). The application of evidence-based practice to nonspeech oral motor treatments. Language, Speech, and Hearing Services in Schools, 39, 408421.

Lof, G. L. \& Watson, M. M. (2008). A nationwide survey of nonspeech oral motor exercise use. Language, Speech, and Hearing Services in Schools, 39 392-407.

Mazon, W. E. (2009). The effect of the breath builder ${ }^{\mathrm{TM}}$ on various lung functions and musical performance abilities of clarinet players, Faculty of the SCHOOL OF MUSIC; university of Arizona, retrieved in 20.02.2021 from

http://www.windsongpress.com/jaco bs/written/Mazon\%20-

\%20THE\%20EFFECT\%20OF\%20THE \%2oBREATH\%2oBUILDER\%E2\%84 \%A2\%20ON\%20VARIOUS\%20LUNG \%20FUNCTIONS.pdf

McCauley R.J., Strand E., Lof, G.L., Schooling T. \& Frymark, T. (2009). Evidence-Based Systematic Review: Effects of Nonspeech Oral Motor Exercises on Speech, American Journal of Speech-Language Pathology, 18, 343-360.

Narzisi, A. (2020). Phase 2 and Later of COVID-19 Lockdown: Is it Possible to Perform Remote Diagnosis and Intervention for Autism Spectrum Disorder? An Online-Mediated Approach. Journal of Clinical Medicine, $\quad 9(6), \quad 1850$. https://doi.org/10.3390/jcm9061850

Pamplona, M. del C., \& Ysunza, P. A. (2020). Speech pathology telepractice for children with cleft palate in the times of COVID-19 pandemic. International Journal of Pediatric Otorhinolaryngology, 138, 110318. https://doi.org/10.1016/j.ijporl.2020.11 $\underline{0318}$

Parsons, D., Cordier, R., Vaz, S., \& Lee, H. C. (2017). Parent-mediated intervention training delivered remotely for children with autism spectrum disorder living outside of urban areas: Systematic review. In Journal of Medical Internet Research (Vol. 19, Issue 8). JMIR Publications Inc. https://doi.org/10.2196/jmir.6651 
Polovoy, C. (2008). Telepractice in schools helps address personnel shortages. In ASHA Leader (Vol. 13, Issue 9).

Samadi, S. A., Bakhshalizadeh-Moradi, S., Khandani, F., Foladgar, M., Poursaid-Mohammad, M., \& McConkey, R. (2020). Using hybrid telepractice for supporting parents of children with asd during the COVID19 lockdown: A feasibility study in Iran. Brain Sciences, 10(11), 1-14. https://doi.org/10.3390/brainsci101108 92

Smith, S. L., \& Titze, I. R. (2017). Characterization of Flow-resistant Tubes Used for Semi-occluded Vocal Tract Voice Training and Therapy. Journal of Voice : official journal of the Voice Foundation, 31(1), 113.e1-113.e8.

https://doi.org/10.1016/j.jvoice.2016.0 4.001

Talaș D. (2015).Terapia tulburărilor de limbaj derulată online. în Revista Română de Terapia Tulburărilor de Limbaj și Comunicare-RRTTLC, I/2015, Nr. 1, ASTTLR, Cluj-Napoca, p.34-40, ISSN: 2457-9262 . DOI: 10.26744/rrttlc.2015.1.1.05

Theodoros, D. (2011). Telepractice in Speech-Language Pathology: The Evidence, the Challenges, and the Future. Perspectives on Telepractice. https://doi.org/10.1044/tele1.1.10

Todd Houston, K., Stredler-Brown, A., \& Alverson, D. C. (2012). More than 150 years in the making: The evolution of telepractice for hearing, speech, and language services. In Volta Review. https://doi.org/10.17955/tvr.112.3.m.70 9
Trifu, R. N., Münch, H., Kleer, F., \& Mészáros, É. (2018). Telepractice in SLT. Results from an european survey. Book of Abstract. 1oth CPLOL European Congress of Speech and Language Therapy, 226.

WIS. (2020). World Internet Users Statistics and 2020 World Population Stats.

https://www.internetworldstats.com/ stats.htm

https://cubulet.ro/

https://www.liveworksheets.com/

https://www.storyboardthat.com/

https://words.eminus.pl/

https://wordwall.net/

http://www.editura.ubbcluj.ro/bd/eboo ks/pdf/2829.pdf

https://www.originalbreathbuilder.com/ https://talktools.com/

https://talktools.com/products/introkit?variant $=28452056905$

${ }^{1 .}$ Conf. univ. dr., Departamentul de Psihopedagogie Specială, Facultatea de Psihologie şi Ştiinţe ale Educaţiei, Universitatea Babeş-Bolyai, Cluj-Napoca; E-mail:carolina.bodea.hategan@gmail.com

${ }^{2}$.Lector asociat dr. Departamentul de Psihopedagogie Specială, Facultatea de Psihologie şi Ştiinţe ale Educaţiei, Universitatea Babeş-Bolyai, Cluj-Napoca; E-mail: tdorina@yahoo.com

3.Asistent universitar dr. Disciplina de Psihologie Medicală, Universitatea de Medicină și Farmacie „Iuliu Hațieganu” Cluj-Napoca.

Email: raluca.trifu@umfcluj.ro 